


\section{Fundamentos e métodos para o ensino de Língua Portuguesa}

Ivo da Costa do Rosário

Monclar Guimarães Lopes

(Organizadores) 
Reitor Ari Miguel Teixeira Ott

Vice-Reitor José Juliano Cedaro

EDITORA DA UNIVERSIDADE FEDERAL DE RONDÔNIA

$\begin{array}{ll} & \text { CONSELHO EDITORIAL } \\ \text { Presidente } & \text { Lou-Ann Kleppa } \\ & \text { Ariana Boaventura Pereira } \\ \text { Carlos Alexandre Trubiliano } & \text { Eliane Gemaque Gomes Barros } \\ & \text { Gean Carla Silva Sganderla } \\ \text { Leandro Soares Moreira Dill } & \text { Márcio Secco } \\ & \text { Marli Lúcia Tonatto Zibetti } \\ & \text { Pedro Ivo Silveira Andretta } \\ & \text { Ricardo Gilson da Costa Silva } \\ & \text { Xênia de Castro Barbosa }\end{array}$

Editora Filiada
Edufro - Editora da Universidade Federal de Rondônia BR 364, Km 9,5
Campus Unir
76801-059 - Porto Velho - RO
Tel.: (69) 2182-2175
www.edufro.unir.br edufro@unir.br




\section{Fundamentos e métodos para o ensino de Língua Portuguesa}

Ivo da Costa do Rosário

Monclar Guimarães Lopes

(Organizadores)

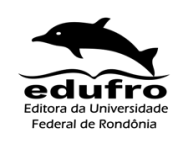

Porto Velho - RO 
(C) 2020 by Ivo da Costa do Rosário e Monclar Guimarães Lopes (Organizadores)

Esta obra é publicada sob a Licença Creative Commons Atribuição-Não

Comercial 4.0 Internacional.

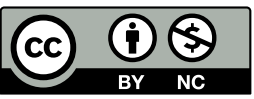

Capa:

Jôsy Monteiro Alves

Revisão:

Dra. Jeane Mari Spera

Projeto gráfico:

Edufro - Editora da Universidade Federal de Rondônia

\author{
Diagramação: \\ Guilherme André de Campos
}

Impressão e acabamento:

Seike \& Monteiro Editora

Aprovado no Edital 02/2018/EDUFRO

Dados Internacionais de Catalogação na Publicação

Fundação Universidade Federal de Rondônia (UNIR)

Ficha Catalográfica elaborada pela Biblioteca Central da UNIR

F981 Fundação Universidade Federal de Rondônia.

Fundamentos e métodos para o ensino de língua portuguesa / organização Ivo da Costa do Rosário, Monclar Guimarães Lopes. - Porto Velho, RO: EDUFRO, 2020.

158 p.; il.

ISBN: 978-65-87539-33-1 (físico)

ISBN: 978-65-87539-30-0 (digital)

1. Metodologia. 2. Produção textual. 3. Leitura. 4. Análise linguística. I. Rosário, Ivo da Costa do. II. Lopes, Monclar Guimarães. III. Fundação Universidade Federal de Rondônia. 


\section{Sumário}

$7 \quad$ Apresentação

Ivo da Costa do Rosário (UFF)

Monclar Guimarães Lopes (UFF)

13 FUNDAMENTOS DIDÁTICO-PEDAGÓGICOS DA LÍNGUA PORTUGUESA: PARA QUÊ, PARA QUEM E O QUE ENSINAR? Monclar Guimarães Lopes (UFF)

37 FUNDAMENTOS DIDÁTICO-PEDAGÓGICOS DA LÍNGUA PORTUGUESA: COMO ENSINAR?

Ivo da Costa do Rosário (UFF)

63 TEXTO EM QUESTÃO: CONCEITOS E APLICAÇÕES Patrícia Ferreira Neves Ribeiro (UFF)

87 ENSINO DE LEITURA: DO ESPECTADOR AO EXPECTADOR Beatriz dos Santos Feres (UFF)

105 PROCESSOS DE CONSTRUÇÃO DE TEXTOS NA ESCOLA: AFINAL DE CONTAS, QUEM SABE ESCREVER?

Fabio André Coelho (UFF)

127 ANÁLISE LINGUÍSTICA E SEMIÓTICA

Monclar Guimarães Lopes (UFF)

157 Sobre os autores 



\section{Apresentação}

Ivo da Costa do Rosário (UFF)

Monclar Guimarães Lopes (UFF)

Esta obra é fruto de um curso de extensão organizado por Ivo da Costa do Rosário e Monclar Guimarães Lopes, professores do Departamento de Letras Clássicas e Vernáculas e do Programa de Pós-Graduação em Estudos da Linguagem da Universidade Federal Fluminense. O principal objetivo do curso foi o de implementar uma metodologia produtiva de ensino de Língua Portuguesa centrada no texto, em consonância com o que preconizam os Parâmetros Curriculares Nacionais de Língua Portuguesa (BRASIL, 1998)1 e a Base Nacional Comum Curricular (BRASIL, 2019)2, dois documentos que servem como referência nacional para balizar os fundamentos, conteúdos e métodos de ensino de língua portuguesa no Brasil.

Como sabemos, a despeito da longa existência de documentos oficiais, como os PCN (BRASIL, 1998), o ensino de língua materna no Brasil continua sendo um desafio: avançamos muito pouco em relação à proficiência de leitura e escrita. Em 2018, por exemplo, a Pesquisa Retratos da Leitura no Brasil ${ }^{3}$ estimou que apenas $25 \%$ das pessoas apresentavam domínio adequado das habilidades de leitura e escrita, índice bastante indesejável até mesmo para países subdesenvolvidos. Sendo assim, cabe à universidade o papel de investigar as causas dessa insuficiência e de apresentar medidas interventivas que visem à sua resolução.

\footnotetext{
${ }^{1}$ Cf. BRASIL. Secretaria de Ensino Fundamental. Parâmetros Curriculares Nacionais de Lingua Portuguesa. 30 e 4º ciclos. Brasília: MEC, 1998.

${ }^{2}$ BRASIL. Secretaria de Ensino Fundamental. Base Nacional Comum Curricular. Brasília: MEC, SEB, 2019.

${ }^{3}$ Os resultados desta pesquisa estão disponíveis em: http://www.abdr.org.br/site/ pesquisa-retratos-da-leitura-no-brasil/ - acesso em 23/10/2018.
} 
Desse ponto de vista, defendemos que esta obra contribua para a formação pedagógica tanto de graduandos quanto de profissionais que já atuem na docência da Língua Portuguesa. Por isso, fundamentamo-nos não somente nos documentos oficiais supracitados, como também em pesquisas linguísticas recentes, que busquem, entre outros objetivos: a) investigar por que os índices de leitura e escrita ainda são insuficientes; b) apresentar alternativas metodológicas que visem a garantir o desenvolvimento da competência discursiva, levando em consideração os diferentes públicos, especialmente aqueles advindos das camadas sociais menos favorecidas, em que o nível de letramento costuma ser ainda mais insuficiente; c) reconhecer a linguagem sobre um espectro mais amplo, isto é, para além do código linguístico, promovendo a investigação e o tratamento didático para as diversas semioses; d) valorizar o multiletramento, isto é, ter uma visão mais ampla de cultura, que leve em consideração aquilo que é produzido e consumido por diferentes estratos sociais.

No intuito de atender a esses objetivos específicos, este livro organiza-se em seis capítulos, cujos temas abordam: a) a finalidade, o sujeito e o objeto de aprendizagem; b) o planejamento e a organização das atividades didáticas; c) abordagens para o desenvolvimento da competência leitora (de textos de diferentes semioses); d) tratamento didático para a produção de textos; e) ensino produtivo de gramática, isto é, de uma gramática do texto. Todos os capítulos foram produzidos por professores doutores convidados, com ampla experiência no ensino de Língua Portuguesa, tanto na educação básica quanto no ensino superior. Apesar de tratarem de temas distintos, são fortemente comunicáveis entre si, visto que se complementam na construção de um mosaico representativo do que se entende por ensino de Língua Portuguesa, de diferentes pontos de vista. Em sequência, apresentamos um breve resumo do que será tratado em cada capítulo.

No Capítulo 1, Fundamentos didático-pedagógicos da Lingua Portuguesa: para quê, para quem e o que ensinar?, Monclar Guimarães Lopes trata de três pontos imprescindíveis para o ensino de língua materna: a finalidade, o sujeito e o objeto da aprendizagem. Segundo o autor, esses pontos estão hierarquicamente organizados, isto é, primeiro precisamos entender por 
que ensinamos Língua Portuguesa; depois, quem é esse sujeito da aprendizagem e como ele aprende; para, só então, definirmos os objetos de ensino. No que tange à finalidade, uma vez que o objetivo principal do ensino de língua materna é o desenvolvimento da competência discursiva, a unidade didática não pode se restringir aos estratos da língua, como fonemas, morfemas, palavras e períodos, mas, sim, deve contemplar o texto. Paralelamente, é preciso entender quem é esse sujeito e como ele aprende. Afinal, a abordagem sistemática e descontextualizada da gramática tem sido infrutífera nas classes sociais menos abastadas, cujas práticas de letramento são mais escassas e cuja variedade linguística é bastante distinta daquelas materializadas nos textos que circulam no espaço escolar. Só a partir dessa compreensão que podemos melhor selecionar o objeto de ensino, isto é, saber o que é preciso ensinar (levando em consideração os pré-requisitos) para atingir os objetivos pretendidos.

Em Fundamentos didático-pedagógicos da Lingua Portuguesa: como ensinar?, Ivo da Costa do Rosário apresenta uma metodologia de ensino fundamentada em sequências didáticas. Partindo da abordagem elaborada por três pesquisadores franco-suíços, o autor mostra como pode o docente planejar "um conjunto de atividades escolares organizadas, de maneira sistemática, em torno de um gênero textual oral ou escrito" (DOLZ, NOVERRAZ e SCHNEUWLY, 2004, p. 97) 4 .

Grosso modo, o modelo proposto tem o texto como unidade básica, funcionando como ponto de partida e como ponto de chegada de todo processo. Trata-se de uma perspectiva de base funcional e sociointeracionista, que visa ao desenvolvimento da competência discursiva, por meio da expansão progressiva das práticas de letramento, tanto no que diz respeito à recepção (leitura e escuta) quanto à produção (escrita e fala). A metodologia também é construída sob a perspectiva da avaliação formativa, comprometida com a aprendizagem real dos alunos, na medida em que só

\footnotetext{
${ }^{4}$ DOLZ, Joaquim; NOVERRAZ, Michele; SCHNEUWLY, Bernard. Sequências didáticas para o oral e a escrita: apresentação de um procedimento. In: DOLZ, Joaquim; SCHNEUWLY, Bernard e colaboradores. Gêneros orais e escritos na escola. Trad. e Org. de Roxane Rojo e Glaís Sales Cordeiro. Campinas, SP: Mercado das Letras, 2004.
} 
se avança para uma próxima etapa quando os objetivos estabelecidos são devidamente alcançados.

No capítulo 3, Texto em questão: conceitos e aplicações, Patrícia Ferreira Neves Ribeiro parte dos conceitos de linguagem e língua, bem como das suas funções, para definir texto, contexto e discurso. Afinal, sob uma perspectiva do ensino, é necessário entender as funções comunicativa, social e simbólica da linguagem, como elas se materializam na língua - compreendida como forma ("lugar") da interação - e como tudo isso se relaciona com o texto e os discursos que produzimos.

Segundo a autora, ao se enxergar o texto em sua dimensão discursiva, entendemos por que o processo de leitura mobiliza diversas áreas do conhecimento. O leitor proficiente não é aquele que somente reconhece o código linguístico, mas, sim, aquele que aciona um conjunto de conhecimentos (linguístico, enciclopédico e interacional), no que diz respeito às encenações estratégicas de sujeitos em interação, sob determinadas condições contratuais, para a construção dos efeitos de sentido do texto.

No Capítulo 4, Ensino de leitura: do espectador ao expectador, Beatriz dos Santos Feres diferencia o ato de compreender do ato de interpretar. Segundo a autora, existem leitores que, embora alfabetizados, apenas compreendem os sentidos mais superficiais e objetivos do que leem, pois são incompetentes em interpretar o sentido global do texto ou em fazer inferências a partir de um diálogo entre o texto e o contexto de circulação.

No intuito de formar leitores proficientes, isto é, que não sejam meros espectadores, mas expectadores (nas palavras de Beatriz), a professora fala da importância do desenvolvimento das competências leitoras, a saber: a competência semiolinguageira, a competência discursiva e a competência situacional. Ademais, em suas análises, Feres lança um olhar especial ao texto multimodal verbo-visual, cujas estratégias leitoras têm sido, ainda, pouco exploradas na Educação Básica.

Em Processos de construção de textos na escola: afinal de contas, quem sabe escrever?, Fabio André Coelho objetiva apresentar possibilidades de trabalho para a construção de textos em sala de aula, partindo das condições reais de produção até a revisão. Nesse processo, o autor chama a atenção para os 
diferentes aspectos que devem ser considerados pelo professor no desenvolvimento dos textos, tais como a natureza linguística do texto, a apropriação dos recursos linguísticos, a visão de mundo, os sentidos das palavras nos contextos de uso, os diferentes domínios da linguagem e a importância da valorização e de um tratamento adequado da oralidade.

O autor alerta sobre a importância de se trabalhar o texto a partir de situações interativas, em que o aluno seja levado a escrever para um destinatário específico, tendo em mente fins também específicos, na ideia de que a escrita puramente ensaísta e artificial não favorece o desenvolvimento da proficiência da escrita. Paralelamente, ressalta a importância de valorizar a diversidade textual em sala de aula, isto é, promover a expansão da prática de letramento por meio do acesso à leitura e escrita de diferentes gêneros de texto.

Análise linguística e semiótica, de Monclar Guimarães Lopes, apresenta uma abordagem contextualizada da gramática, isto é, pautada em textos. Segundo o autor, uma gramática cujo escopo máximo de análise é o período e cujos níveis recobrem apenas os aspectos fonológicos, morfológicos, sintáticos e semânticos é insuficiente. Argumenta que uma gramática de texto precisa prever unidades transfrásicas (isto é, o próprio texto), assim como precisa considerar os níveis pragmático (no que tange à intencionalidade e aos papéis desempenhados pelos interlocutores) e discursivo-funcional (no que se refere às sequências tipológicas, aos gêneros e às modalidades de texto).

Paralelamente, o professor apresenta uma abordagem para o trabalho com outras semioses, haja vista que lidamos, cotidianamente, com variados textos multissemióticos. Segundo Lopes, as diferentes semioses (sobretudo, a imagem) assumem um papel altamente relevante no ensino contemporâneo, na medida em que elas são amplamente exploradas para a produção de sentidos, muitas vezes, inclusive, de maneira inadequada e criminosa, como podemos observar em relação às fake news.

Esperamos que este livro possa trazer importantes reflexões aos leitores e contribua, substancialmente, para a sua formação. Desejamos-lhe uma ótima leitura! 



\section{FUNDAMENTOS DIDÁTICO-PEDAGÓGICOS DA LIINGUA PORTUGUESA: PARA QUÊ, PARA QUEM E OQUE ENSINAR?}

Monclar Guimarães Lopes (UFF)

\section{Objetivos}

Ao final deste capítulo, você deve ser capaz de compreender...

- por que a prática de ensino da Língua Portuguesa deve centrar-se nas necessidades do sujeito da aprendizagem;

- por que o texto é considerado a unidade básica de ensino de Língua Portuguesa nos documentos pedagógicos oficiais;

- que a principal função do ensino da Língua Portuguesa é o desenvolvimento da competência discursiva por meio das práticas de multiletramento.

Talvez eu possa neutralizar um pouco a ideia equivocada de que a gramática basta; ou a outra de que a gramática se esgota na simples classificação de suas categorias.

(ANTUNES, 2010, p. 19)

\section{Introdução}

Há duas décadas, o Ministério da Educação e a Secretaria de Educação Fundamental lançaram os Parâmetros Curriculares Nacionais de Língua Portuguesa (PCN), um conjunto de diretrizes educacionais cuja principal finalidade é a de orientar as práticas pedagógicas de ensino de língua materna no Brasil. Conforme sabemos, os PCN fundamentam-se em uma série de pesquisas nacionais e internacionais na área da Linguística e do ensino que, em síntese, sustentam os seguintes pontos: a) o fracasso nas habilidades de leitura e escrita na Educação Básica está associado a uma metodologia pautada, quase exclusivamente, em uma gramática 
descontextualizada, cuja maior unidade de análise é o período; b) o processo de ensino-aprendizagem é mais eficiente quando se dá por meio de uma relação dialética, em que se considerem os conhecimentos prévios dos alunos; c) o principal objetivo do ensino de Língua Portuguesa é o pleno desenvolvimento da competência discursiva, cuja obtenção resulta da promoção de múltiplas e variadas práticas de letramento.

Apesar da longa existência dos PCN, vale ressaltar que as proposições apresentadas nesse documento continuam pertinentes e atuais. Inclusive, os mesmos pressupostos encontram-se consubstanciados na última versão da Base Nacional Comum Curricular (BNCC), que também assume "a centralidade do texto como unidade de trabalho" (BRASIL, 2018, p. 65). Basicamente, a BNCC representa tanto uma expansão da fundamentação teórica quanto um refinamento do que já apresentavam os PCN ao final da década de 1990, conforme exploraremos mais adiante neste capítulo.

Talvez, nesse momento, o leitor possa estar se perguntando por que um ensino de Língua Portuguesa centrado em uma abordagem descontextualizada da gramática é necessariamente ineficaz. Afinal, os resultados da escola pública brasileira da primeira metade do século XX podem servir como um contra-argumento. Nesse período, o ensino de português se dava por meio dos próprios manuais de gramática, restritos à metalinguagem (no que diz respeito à análise de estratos linguísticos que vão da letra à frase) e à prescrição da norma padrão para todas as situações de comunicação. A esse respeito, contudo, podemos fazer duas ponderações: 1) até a primeira metade do século XX, a educação pública era universal apenas para o ensino da alfabetização. Nas séries posteriores, o público-alvo era a classe média-alta, cujos membros possuíam práticas variadas de letramento, por meio tanto do acesso a bens culturais diferenciados, quanto da leitura de exemplares de textos de gêneros diversificados; 2) cada vez mais, vivemos em uma cultura letrada, mediada por textos multissemióticos e multimidiáticos de variados gêneros, o que torna injustificáveis e anacrônicos os métodos e conteúdos centrados apenas na estrutura da língua, sobretudo na perspectiva da gramática tradicional, cujos estudos 
não atendem a unidades superiores à frase. Hoje, por sua vez, sabemos da existência de uma gramática discursiva e/ou textual, cuja unidade de análise é o texto, o que pode ser verificado em estudos que descrevem a macrossintaxe do discurso, como, por exemplo, os de Anscombre e Ducrot (1983) e Matthiessen e Thompson (1988).

Dessa maneira, podemos compreender por que, com a universalização da Educação Básica a partir da segunda metade do século XX, tornou-se imperiosa uma reestruturação do ensino de língua materna no Brasil. Uma vez que grande parte dos alunos advindos das camadas menos abastadas da população vivia em comunidades onde praticamente inexistiam práticas de letramento da cultura escrita, um ensino voltado para a gramática teórica e normativa não surtiu o efeito desejado. Muito pelo contrário, os resultados só evidenciavam o fracasso escolar, haja vista o mau desempenho nas habilidades de leitura e escrita, bem como os elevados índices de evasão e repetência escolar, "inaceitáveis mesmo em países muito mais pobres"(BRASIL, 1998, p. 17). Isso posto, cabe à escola promover práticas contínuas de letramento, de modo a garantir o pleno exercício da cidadania, haja vista que: a) o artigo 205/1988 da Constituição Federal (SENADO, 2015 [1988]) assegura o direito à educação, com vistas ao pleno desenvolvimento da pessoa, seu preparo para o exercício da cidadania e sua qualificação para o trabalho; b) o artigo 3\%/1988 desse mesmo documento estabelece como objetivo fundamental a erradicação da pobreza e da marginalidade, bem como a redução das desigualdades sociais e regionais. Entendemos, assim, que é um compromisso da escola procurar oferecer igualdade de oportunidades a todos os alunos, independentemente dos estratos sociais a que pertencem e das condições em que vivem.É exatamente por esse motivo que os $\mathrm{PCN}$ afirmam que

[...] um projeto educativo com a democratização social e cultural atribui à escola a função e a responsabilidade de contribuir para garantir a todos os alunos o acesso aos saberes linguísticos necessários para o exercício da cidadania. Essa responsabilidade é tanto maior quanto menor for o grau de letramento das comunidades em que vivem os alunos (BRASIL, 1998, p. 19). 
Sob esse ponto de vista, entende-se que o processo de ensino deve estar centrado no sujeito da aprendizagem, levando sempre em consideração suas necessidades específicas. Por isso, busca-se trabalhar, de um lado, com a concepção de avaliação formativa, em que os conhecimentos prévios dos alunos exercem papel muito relevante no planejamento pedagógico; de outro, com a teoria sócio-interacionista vygotskiana, aliada às abordagens do letramento e às do texto/discurso, que nos "possibilitam considerar aspectos cognitivos, sócio-políticos, enunciativos e linguísticos envolvidos no processo de ensino-aprendizagem de uma língua” (BEZERRA, 2007, p. 38).

Não obstante este último apontamento, que se refere à centralidade do educando no processo educativo, devemos salientar que só é possível proceder a uma avaliação diagnóstica do conhecimento prévio de nossos alunos quando temos clareza acerca da finalidade do ensino de língua materna na Educação Básica. Sendo assim, tendo em mente que o pleno desenvolvimento da competência discursiva é o objetivo principal no ensino de língua materna, devemos aferir quais habilidades linguísticas os alunos ainda não dominam ou, ainda, dominam parcialmente. Grosso modo, uma vez que a competência discursiva só pode ser desenvolvida por meio de atividades também discursivas, o texto passa a ser considerado a unidade básica de análise. Nessa perspectiva, até as práticas de análise linguística (gramática) só se justificam no texto, uma vez que esse tipo de conhecimento é instrumental em relação às habilidades de leitura/escuta e escrita/fala.

Feitas as considerações iniciais, tratemos agora da organização deste capítulo, dividido em cinco partes. Em para que ensinar, buscamos explicar dois objetivos gerais da Educação Básica e seus desdobramentos no ensino de Língua Portuguesa. Em para quem ensinar, discutimos a importância de uma metodologia de ensino centrada no educando, com base em reflexões oriundas da teoria sócio-interacionista e da perspectiva da avaliação formativa. Em o que ensinar, defendemos uma metodologia de ensino baseada em gêneros textuais, materializados em diferentes modalidades e múltiplas semioses, circunscritos a domínios discursivos variados. Por fim, apresentamos um exercício e um resumo do capítulo, além das referências bibliográficas. 


\section{Para que ensinar?}

De acordo com as Diretrizes Curriculares Nacionais (BRASIL, 2013), a Educação Básica visa à formação integral do ser humano e à redução das distâncias sociais, objetivos que só podem ser alcançados por meio tanto da promoção da igualdade de oportunidades quanto de ações combativas a todas as formas de discriminação, preconceito e exclusão. No que tange, particularmente, ao ensino de língua materna, esse compromisso se realiza pela promoção de práticas múltiplas e variadas de letramento, que garantam acesso aos diferentes espaços e conhecimentos, e também pela legitimação de nossa diversidade linguística e cultural. A seguir, vamos nos concentrar em explicar de que modo esses últimos aspectos colaboram para uma educação justa, igualitária e emancipatória.

É preciso esclarecer que, em um passado não muito distante, tinha-se a ideia de que o texto era um conjunto de frases e que a escrita era uma mera tecnologia da fala. Sob esse ponto de vista, dominar a escrita correspondia a saber transpor o pensamento para o papel. Por isso, durante muito tempo, acreditou-se que a alfabetização e o ensino da gramática da frase eram suficientes para o desenvolvimento da modalidade escrita. Em contrapartida, hoje, com os estudos do texto e do discurso, sabemos que o registro escrito apresenta modos de organização diversificados e bem distintos da oralidade. Entendemos também que ambas as modalidades se desenvolvem por toda a vida, tanto em sua recepção quanto em sua produção. Ou seja, tornamo-nos progressivamente melhores nas habilidades do ler/escrever e falar/ouvir. É exatamente dessa ideia de processo contínuo que surge a concepção de letramento, tão empregada nos documentos oficiais e políticas educacionais.

É preciso chamar a atenção para o fato de que alfabetização e letramento não são conceitos análogos. Aquela está relacionada à aquisição da tecnologia do ler e escrever, enquanto este se refere às práticas sociais mediadas pela escrita, como tecnologia e sistema simbólico, circunscritas a contextos específicos e orientadas para certos fins (KLEIMAN, 1995, p. 19). Trata-se da escrita situada em gêneros de texto. Atualmente, por sua 
vez, há uma expansão do próprio conceito inicial de letramento, não apenas no que diz respeito à inclusão da modalidade oral, como também à de diferentes semioses.

De um lado, como sabemos, a oralidade não é constituída apenas da conversação face a face. Assim como a escrita, há gêneros diversificados (isto é, caracterizados por tema, estrutura composicional e estilo distintos), que emergem nas sociedades em virtude de novas necessidades e práticas culturais, como a entrevista oral e o seminário, por exemplo. Inclusive, não raro, observamos que os alunos têm bastante dificuldade na produção desse gênero, na medida em que tentam reproduzir fielmente um texto escrito, seja por meio de leitura, seja por meio de uma fala memorizada. Como consequência, não atingem os objetivos previstos, porque não procedem à retextualização necessária. Isso ilustra que os gêneros da modalidade oral precisam ser explorados nas escolas, do mesmo modo que os da modalidade escrita.

De outro lado, cada vez mais as outras semioses assumem importância no processo comunicativo. Não se tem mais a ideia de que as estratégias de construção de sentidos só devem ser exploradas, na Educação Básica, no âmbito da língua. Assim, reconhecemos que a imagem, a melodia, a cinese, o ritmo, entre outros, representam planos de expressão significativos e, por isso, passíveis de descrição. No caso da imagem, especificamente, a sua grande semelhança com a própria realidade favorece os processos de manipulação de sentidos. Temos vivido uma época em que as tecnologias da imagem e do som estão bastante desenvolvidas e acessíveis, de modo a possibilitar a rápida viralização de publicações/conteúdos falsos, que são facilmente consumidos como verdade por grande parte dos leitores. Em setembro de 2018, por exemplo, momento em que este texto foi escrito, a edição de vídeos e fotografias na produção de factoides foi uma estratégia recorrentemente empregada por movimentos políticos adversários nas redes sociais, que (re)produziram e disseminaram discursos de ódio com o fito de derrotar seus oponentes e conquistar novos eleitores. Devido a essa prática altamente nociva, muito comum nas redes sociais, urge a emergência de novas políticas públicas para sua punição e prevenção. No que diz respeito à prevenção no âmbito educacional, a última versão da BNCC (BRASIL, 
2018, p. 66) defende a necessidade de conscientizarmos nossos alunos acerca do fenômeno da pós-verdade nas aulas de Língua Portuguesa, mostrando-lhes a importância de se verificarem a fonte e a procedência da informação.

Como podemos ver, a cultura digital nos exige uma nova forma de selecionar, interpretar e produzir textos, e esse conhecimento está estruturado nos variados gêneros. Por conseguinte, faz-se mister reconhecer que vivemos em um mundo discursivo, cujos textos (re)constroem a própria realidade, na medida em que o processo de significação e as ações humanas conforme as conhecemos são, em certa medida, atravessados pelos textos que produzimos. Por esse motivo, Bazerman (2006, p. 23) assim define os gêneros textuais:

Gêneros não são apenas formas. Gêneros são formas de vida, modos de ser. São frames para a ação social. São ambientes para a aprendizagem. São os lugares onde o sentido é construído. Os gêneros moldam os pensamentos que formamos e as comunicações através das quais interagimos. Gêneros são os lugares familiares para onde nos dirigimos para criar ações comunicativas inteligíveis uns com os outros e são os modelos que utilizamos para explorar o não-familiar.

Vale ressaltar que, recentemente, essa concepção mais ampla de letramento foi novamente ressignificada e, agora, tem um novo rótulo, o de multiletramentos. Nesse sentido, além de se trabalharem gêneros de diferentes modalidades e materializados por diferentes semioses, busca-se valorizar a diversidade cultural, mediante a rejeição de

[...] um raciocínio classificatório reducionista, que desconsidera as hibridizações, apropriações e mesclas, [sendo] importante contemplar o cânone, o marginal, o culto, o popular, a cultura de massa, a cultura das mídias, a cultura digital, as culturas infantis e juvenis, de forma a garantir uma ampliação de repertório e uma interação e trato com o diferente (BRASIL, 2018, p. 67).

Durante muito tempo, defendemos que uma educação justa, igualitária e emancipatória só seria possível quando todos tivessem acesso aos bens 
culturais de "primeira linha", isto é, àqueles produzidos segundo os padrões da classe dominante, o que representa uma visão estereotipada e preconceituosa do termo cultura. É estereotipada porque delimita as manifestações culturais a um conjunto muito restrito; preconceituosa porque recrimina (e, muitas vezes, criminaliza) todas as outras. Sob essa mesma ótica, Souza (2017, p. 16) apresenta o termo culturalismo, que pode ser entendido como "uma espécie de 'senso comum internacional' para a explicação das diferenças sociais e de desenvolvimento relativo no mundo inteiro". Trata-se de um rótulo que abriga um racismo implícito, sob a crença de que existe "uma separação ontológica entre seres humanos de primeira classe e seres humanos de segunda classe" 1 . O autor ainda reforça que essa é uma prática cientificamente falsa, que cumpre funções análogas ao racismo da cor da pele e "presta-se a garantir uma sensação de superioridade e de distinção para os povos e países que estão em situação de domínio e, desse modo, legitimar e tornar merecida a própria dominação". ${ }^{2}$ Sendo assim, uma vez que cabe à escola a desmistificação de preconceitos, uma das estratégias para o combate à discriminação cultural, no ensino de Língua Portuguesa, é oferecer aos alunos o acesso a textos e gêneros produzidos por diferentes estratos e grupos sociais.

Um último aspecto de grande importância no ensino de língua materna a ser tratado nesta seção, diretamente relacionado à questão da emancipação e do combate ao preconceito, é o tratamento dado à diversidade linguística. Atualmente, reconhecemos, como cientistas do estudo da linguagem, que "a variação é constitutiva das línguas humanas, ocorrendo em todos os níveis (...), independentemente de qualquer ação normativa” (BRASIL, 1998, p. 29). Isso significa dizer que nenhum estrato ou grupo social, de quaisquer línguas naturais, emprega exclusivamente a norma padrão ou culta, sobretudo na modalidade oral. Inclusive, admitimos que existem circunstâncias sociais em que o emprego da norma padrão pode ser visto como inadequado à situação. Como exemplo, podemos citar a linguagem empregada pelo personagem Chico Bento, de Maurício de Souza.

\footnotetext{
${ }^{1}$ Souza, 2017, p. 18 .

${ }^{2}$ Souza, 2017, p. 18.
} 
Temos a certeza de que o cartunista domina a norma padrão e faz uso dela em muitas situações de comunicação, a despeito de empregar a variedade caipira para representar as falas desse personagem. Ocorre que o emprego da variedade padrão ou culta nessas circunstâncias incorreria em uma artificialidade e, por isso, em uma possível recusa do texto, na medida em que a variedade caipira é um uso linguístico característico de certas regiões e populações do país.

Além do exemplo supracitado, deveras caricato, recorrentemente podemos constatar que, até em situações sociais de linguagem altamente monitorada, a variação se apresenta. Diariamente, encontramos usos desviantes da norma padrão na impressa escrita e televisiva. Como ilustração, podemos citar uma fala de Alexandre Garcia, jornalista da Rede Globo de Televisão, que, ao criticar um livro didático de Língua Portuguesa que abordava a questão da variação linguística em 2011, perguntou ao telespectador: "Onde fica as regras de concordância?". Ironicamente, ao deixar subentendido que, nas diferentes situações linguísticas, só cabe o uso da norma padrão, o próprio jornalista incorreu em desvio.

Vale ressaltar, porém, que, a despeito de todo um trabalho de conscientização e de combate ao preconceito às diferentes variedades linguísticas, cabe à escola e ao professor de Língua Portuguesa ensinar a norma padrão nas escolas. Como sabemos, existem circunstâncias sociais, mediadas por gêneros textuais mais monitorados, em que o uso da norma padrão é exigido. Dessa maneira, só é possível promover a igualdade de oportunidades se os alunos souberem como empregar a variedade linguística adequada nos diferentes gêneros de texto.

\section{Para quem ensinar?}

Em 1690, Locke defendia, em seu livro Ensaio acerca do entendimento (LOCKE, 2005 [1690]), a tese de que o ser humano nasce como uma "tábula rasa" a ser preenchida pelos pais e pela sociedade. Infelizmente, esse tipo de pensamento constituiu (e, em certa medida, constitui) parte dos alicerces das práticas de ensino vigentes. Durante muito tempo, defendeu-se que a 
aprendizagem se dava mediante uma metodologia passiva, em que o conhecimento do professor era transferido às mentes dos alunos por meio da mera exposição das informações. Tal ponto de vista reproduz a ideia de que todos aprendem do mesmo jeito e costuma responsabilizar exclusivamente o aluno pelo próprio insucesso. Não coincidentemente, o público que fracassa costuma ser o de estratos sociais mais baixos, constituído por maioria negra, o que ajuda a reforçar a falsa ideia de que há uma raça superior à outra.

Felizmente, diversos estudos recentes nas áreas da psicologia, da cognição e da neurociência têm evidenciado que esse ponto de vista é totalmente equivocado e discriminatório. Longe de serem uma folha em branco a ser preenchida, as pessoas adquirem conhecimento por meio de interações dialógicas tanto entre indivíduos em um grupo social quanto entre indivíduos e o meio cultural e social em que estão inseridos. Sendo assim, podemos entender por que um aluno de classe média de região urbana, que consome textos de diferentes gêneros fora da escola, tem acesso a diferentes bens culturais e fala uma variedade linguística mais próxima à de prestígio, aprende com mais facilidade que um aluno de classe baixa, que vive em uma comunidade não letrada e fala uma variedade linguística bastante distinta da variedade padrão. Ou seja, o fracasso escolar está diretamente associado à falta de acesso à cultura letrada, e não a deficiências de ordem cognitiva.

Segundo a Teoria Sócio-Interacionista (VYGOTSKY, 1999), o conhecimento se (re)constrói por intermédio de sistemas simbólicos que representam a realidade (sendo a linguagem o principal de todos os sistemas), cujo desenvolvimento se dá por meio de processos cognitivos gerais, tais como a capacidade de generalização, de dedução, de associação, de categorização, entre outros. Isso posto, é preciso compreender que a aprendizagem de sistemas mais abstratos de conhecimento, como a expressão linguística em textos escritos nos diferentes gêneros, por exemplo, não ocorre de maneira transmissiva. $\mathrm{Na}$ verdade, esse tipo de aprendizagem depende da atuação de inúmeros processos mentais, que se desenvolvem por intermédio da prática e da reflexão contínuas. Vale ressaltar que essa ideia de processo pode ser facilmente evidenciada, por exemplo, quando observamos a evolução do texto dissertativo-argumentativo de um adoles- 
cente ao longo do tempo. Como sabemos, a produção desse tipo de texto exige do autor um raciocínio altamente abstrato e analítico, materializado na seleção, hierarquização e organização de argumentos para a defesa de um ponto de vista. Portanto, é bastante natural que o aluno apresente dificuldades iniciais em relação ao gênero, que vão sendo superadas, ao longo do tempo, nas práticas de produção e reescrita de textos.

Dessa maneira, podemos entender que, em uma abordagem sóciointeracionista da aprendizagem, pressupõe-se que as formas mais abstratas e complexas de pensamento não podem ser transmitidas de uma mente para a outra, na medida em que precisam ser desenvolvidas na mente do próprio aprendiz, pelos processos cognitivos gerais supracitados. Cabe frisar que, com essa afirmação, não queremos dizer que a escola deixará de lidar com o conhecimento científico construído e acumulado pela humanidade ao longo do tempo, mas, sim, que cabe à escola proporcionar desafios e estímulos à mente do indivíduo, com o intuito de levá-lo a conquistar estágios superiores de raciocínio.

De acordo com Rego, nesse tipo de abordagem, os seguintes aspectos devem ser levados em consideração ${ }^{3}$ :

a) a afirmação de que o bom ensino é o que se adianta ao desenvolvimento, favorecendo a complementação de funções psicológicas que estão se processando (para isso, são importantes ações que interfiram no que o autor chamou de zona de desenvolvimento proximal, estágio em que o indivíduo ainda não tem autonomia para resolver problemas sozinhos, precisando da contribuição de outrem);

b) o papel do outro na construção do conhecimento (para que o indivíduo se aproprie do patrimônio material e simbólico que a humanidade construiu ao longo da história, é preciso a mediação de indivíduos mais experientes; assim, o processo externo concretizado nas atividades entre as pessoas se transforma em processo intrapsicológico, onde a atividade é reconstruída internamente. Portanto, construir conhecimento implica uma ação partilhada);

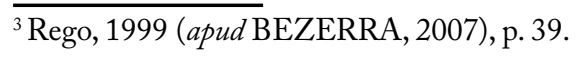


c) o papel da imitação no aprendizado (a imitação - não puramente de cópia e repetição, mas como instrumento de compreensão - proporciona a oportunidade de reconstrução interna do que o indivíduo observa externamente, ampliando sua capacidade cognitiva);

d) o papel mediador do professor nas interações interpessoais e na interação dos alunos com objetos de conhecimento (o professor deixa de ser o agente exclusivo da informação e formação dos alunos, para ser possibilitador das interações entre eles e também responsável pela intervenção nas suas zonas de desenvolvimento proximal, já que tem mais experiência e a incumbência de desafiar, através do ensino, os processos de aprendizagem e desenvolvimento dos alunos).

Conforme podemos depreender, saímos de uma prática protagonizada pelo professor para uma outra, na qual o aluno é o centro. Sob essa ótica, o processo de ensino-aprendizagem tem um compromisso estreito com as reais necessidades dos alunos. Por conseguinte, no lugar de um currículo pré-estabelecido e invariável, deve o docente proceder a uma avaliação diagnóstica de sua turma, de modo a aferir, em seu grupo, quais habilidades os alunos dominam com proficiência, bem como aquelas que não dominam ou dominam parcialmente. Trata-se de um procedimento necessário para o planejamento didático, já que a desconsideração dos conhecimentos prévios (que muitas vezes são pré-requisito para a compreensão de novos conteúdos e/ou habilidades) costuma incidir fortemente sobre os índices de fracasso escolar. Isso não significa, no entanto, que seja inviável o planejamento de um currículo comum para as diferentes séries/anos de escolaridade, apenas diz respeito ao reconhecimento de novos procedimentos ou percursos que precisam ser traçados para pôr os trilhos nos eixos.

Podemos entender que um processo de ensino comprometido com o sucesso escolar só é possível por intermédio de práticas que envolvam as seguintes fases: 1) diagnóstico inicial; 2) planejamento de objetivos e sequências de atividades que visam à aquisição de novos conhecimentos e ao desenvolvimento de habilidades; 3) novo diagnóstico. Essas três fases são cíclicas, pois só se encerra um processo quando o novo diagnóstico evidenciar que os objetivos previamente estabelecidos foram atingidos. 
Grosso modo, o processo aqui ilustrado é descrito na Pedagogia sob o rótulo de avaliação formativa, definida por Fernandes (2005, p. 356-357), como uma avaliação

[...] deliberadamente organizada para proporcionar um feedback inteligente e de elevada qualidade tendo em vista melhorar as aprendizagens dos alunos; o feedback é determinante para ativar os processos cognitivos e metacognitivos dos alunos, que, por sua vez, regulam e controlam os processos de aprendizagem, assim como para melhorar a sua motivação e autoestima; a natureza da interação e da comunicação entre professores e alunos é absolutamente central porque os professores têm de estabelecer pontes entre o que se considera ser importante aprender e o complexo mundo dos alunos (o que eles são, o que sabem, como pensam, como aprendem, o que sentem, como sentem, etc.); os alunos são deliberada, ativa e sistematicamente envolvidos no processo do ensino-aprendizagem, responsabilizando-se pelas suas aprendizagens e tendo amplas oportunidades para elaborarem as suas respostas e para partilharem o que e como compreenderam; as tarefas propostas aos alunos que, desejavelmente, são simultaneamente de ensino, de avaliação e de aprendizagem, são criteriosamente selecionadas e diversificadas, representam os domínios estruturantes do currículo e ativam os processos mais complexos do pensamento (e. g., analisar, sintetizar, avaliar, relacionar, integrar, selecionar); as tarefas refletem uma estreita relação entre as didáticas específicas das disciplinas e a avaliação, que tem um papel relevante na regulação dos processos de aprendizagem.

Em síntese, pelas considerações feitas nesta seção, entendemos que um planejamento didático só deve ser feito quando levamos em consideração a identidade e a realidade de nossos próprios alunos. Inclusive, do ponto de vista análogo, os PCN de Língua Portuguesa (BRASIL, 1998, p. 22) defendem que o aluno é a variável mais importante no processo de ensino aprendizagem, estando à frente do conteúdo a ser ensinado e do próprio professor. 


\section{O que ensinar?}

Os documentos oficiais, como os PCN de Língua Portuguesa (BRASIL, 1998), as DCN (BRASIL, 2013) e a BNCC (BRASIL, 2018), consideram que o principal objetivo do ensino da Língua Portuguesa é o desenvolvimento da competência discursiva dos educandos e, por isso, assumem o texto como sua unidade básica. Como sabemos, a competência discursiva diz respeito à capacidade "de utilizar a língua de modo variado, para produzir diferentes efeitos de sentido e adequar o texto a diferentes situações de interlocução oral e escrita” (BRASIL, 1998, p. 23). Desse ponto de vista, todo o planejamento didático deve ter o texto como ponto de partida e de chegada, isto é, deve visar à proficiência das habilidades do ler/escutar e escrever/falar.

Metodologicamente, essa perspectiva se materializa em um ensino pautado nos diversos gêneros textuais. Afinal, em uma sociedade organizada por uma variedade de textos, entende-se que a proficiência comunicativa esteja atrelada à capacidade de interpretar/compreender e produzir textos em diferentes situações de interlocução, seja por meio do emprego da língua (nas modalidades oral e escrita), seja por meio do uso de outras semioses. Cabe lembrar que vivemos em um mundo mediado por textos, que se concretizam em situações e domínios discursivos variados. Nesse sentido, quanto mais nos apropriamos dos diferentes gêneros, tanto melhor interpretamos o mundo e agimos sobre ele.

Dessa maneira, ao reconhecermos que um texto não pode ser definido como um conjunto aleatório de frases, precisamos repensar uma metodologia cujo foco tem sido a análise de estratos, isto é, de letras/fonemas, sílabas, palavras, sintagmas e frases. Sob uma perspectiva textual do ensino de Língua Portuguesa, as unidades didáticas são organizadas em torno dos gêneros de texto (carta, e-mail, bilhete, conto, crônica etc.), sendo a gramática vista como um aspecto secundário, no que diz respeito à sua instrumentalidade. Em síntese, precisamos ter em mente que a gramática está a serviço da comunicação, e nunca o contrário. 
Basicamente, um ensino centrado nos gêneros se concretiza por meio de estratégias que valorizem o desenvolvimento das quatro habilidades comunicativas (ler, ouvir, escrever e falar). Por essa razão, quando uma unidade didática se organiza em torno de um gênero de texto, espera-se tanto que o aluno tenha acesso à leitura de diferentes bons exemplares do gênero em estudo quanto que produza um exemplar, levando em consideração as questões atinentes ao tema, à estrutura composicional e ao estilo, bem como àquelas que dizem respeito ao contexto de produção do discurso (o domínio discursivo, a relação autor-leitor, os papéis sociais e a intencionalidade envolvida, por exemplo). Ou seja, não se pretende que o aluno somente leia inocentemente um texto, aceitando passivamente todos os sentidos pretendidos pelo autor, mas, sim, que seja capaz de questioná-lo ou negá-lo sempre que necessário. Paralelamente, busca-se um produtor de texto que seja capaz de fazer uso finalisticamente orientado da palavra, em situações concretas de interlocução.

Esses dois últimos aspectos podem ser mais bem compreendidos quando entendemos que há, nos textos, uma intencionalidade subjacente. De um lado, quem escreve não o faz apenas para transmitir uma informação, mas para agir sobre o outro. Nessa ótica, um leitor proficiente deve ser capaz de suspeitar do produtor do texto, com base tanto em pistas linguísticas materializadas na superfície do texto como em seu conhecimento enciclopédico e contextual, na busca de depreender a relação entre o papel social do produtor e sua intencionalidade perante o leitor, bem como os diferentes discursos que se materializam naquele texto. Inclusive, em tempos de pós-verdade, trata-se, pois, de um conhecimento fundamental para a desconstrução dos múltiplos factoides com que temos convivido, como as fake nerws, por exemplo. De outro lado, a autoria dos textos que produzimos, sobretudo nos gêneros textuais mais formais e monitorados, só é possível por meio do planejamento de um projeto de texto e sua posterior realização. Sob esse ponto de vista, o aluno deve ser capaz de produzir textos com vistas à obtenção de seus objetivos comunicativos e isso só é possível pela mobilização de estratégias em que ele faça uso da palavra em situações concretas de comunicação. 
Essa última consideração nos faz repensar as práticas de produção de textos na escola, em que se busca aferir tão-somente a capacidade de produzir textos em situações destacadas da própria realidade. Como sabemos, comumente, o aluno escreve apenas para o professor, com o objetivo de tirar uma boa nota, e não com uma finalidade comunicativa em mente. Muitos docentes, por sua vez, não têm interesse no que o aluno tem a dizer e desejam apenas verificar o desempenho linguístico dos estudantes. Como consequência, temos uma produção artificial de textos, que pouco colabora para a autoria dos alunos. É exatamente com base nessa constatação que se defende que a escola, dentro de suas possibilidades, deve planejar situações reais de interação na prática de produção de textos. Por isso, hoje, enfatizam-se projetos como o jornal e a rádio escolar, por exemplo, que nos dão a possibilidade de promover a circulação dos textos produzidos na escola.

Além disso, em uma abordagem de ensino pautada no texto, também se defende um ensino de gramática contextualizada e produtiva. Como sabemos, a abordagem tradicional de gramática nas escolas fundamentava-se nas perspectivas metalinguística e normativa da língua e tinha como objetivo principal transmitir uma gramática teórica e uma série de prescrições de normas de uso, de maneira linear. Segundo Schneuwly e Dolz (2004), estudava-se em manuais de gramática em que, progressivamente, o aluno ia sendo apresentado às categorias da língua. Sendo assim, se o tópico daquela série era morfologia, por exemplo, o aluno via, em uma unidade, todos os aspectos do substantivo, no seguinte do adjetivo, e assim sucessivamente. Nas abordagens textuais, em contrapartida, prioriza-se uma abordagem espiral, em que os conteúdos gramaticais vão sendo trabalhados à medida que são instrumentais para os textos e/ou habilidades que devem ser desenvolvidas. Sob esse ponto de vista, em gêneros do tipo narrativo, por exemplo, um professor deveria priorizar a reflexão, análise e uso dos tempos verbais do pretérito (e não todos os tempos e modos verbais), em virtude da predominância dessas formas nessa sequência tipológica. Ademais, vale lembrar que, sendo o texto a unidade principal de análise, a gramática não se restringe à estrutura do período. Portanto, a macrossintaxe do discurso, no que tange às questões atinentes à coesão interfrasal e interparágrafos, além dos demais fatores de textualidade, devem ser trabalhados na Educação Básica. 
Cabe frisar que, nesse tipo de perspectiva, considera-se que o ensino de gramática tem como objetivo final o desenvolvimento das habilidades comunicativas. Isso significa que o trabalho com a estrutura linguística deve levar o aluno à reflexão de que a gramática é empregada para fins discursivos específicos e de que as construções linguísticas empregadas acarretam diferentes efeitos de sentido, bem como levá-lo a empregar essas estruturas em seu texto de forma proficiente. Ou seja, muito mais do que o reconhecimento de uma nomenclatura gramatical vazia de sentido, mais vale o reconhecimento dos efeitos de sentido dessas estruturas e o seu uso potencial nas produções de texto, com vistas à obtenção dos objetivos comunicativos, dada a instrumentalidade da gramática para a comunicação humana. Mais uma vez, reforçamos: defendemos hoje um domínio de gramática produtiva, contextualizada, que vise ao desenvolvimento das habilidades comunicativas, e não um conhecimento da gramática pela própria gramática.

Segundo Mendonça (2006 apud SANTOS, RICHE E TEIXEIRA, 2015), essa perspectiva mais recente, a que Travaglia (2009) chama de análise linguística (AL), diferencia-se da abordagem tradicional do ensino de gramática por uma série de parâmetros, expressos no Quadro 1:

Quadro 1 - Ensino de gramática vs prática de análise linguística

\begin{tabular}{|l|l|}
\hline Ensino de Gramática & Prática de análise linguística \\
\hline $\begin{array}{l}\text { Concepção de língua como sistema, } \\
\text { estrutura inflexível e invariável. }\end{array}$ & $\begin{array}{l}\text { Concepção de língua como ação } \\
\text { interlocutiva situada, sujeita às inter- } \\
\text { ferências dos falantes. }\end{array}$ \\
\hline $\begin{array}{l}\text { Fragmentação entre os eixos de } \\
\text { ensino: as aulas de gramática não se } \\
\text { relacionam necessariamente com as de } \\
\text { leitura e produção de textos. }\end{array}$ & $\begin{array}{l}\text { Integração entre os eixos de ensino: a } \\
\text { análise linguística é ferramenta para } \\
\text { leitura e a produção de textos. }\end{array}$ \\
\hline $\begin{array}{l}\text { Metodologia transmissiva, baseada } \\
\text { na exposição dedutiva (do geral para } \\
\text { o particular, isto é, das regras para o } \\
\text { exemplo) + treinamento. }\end{array}$ & $\begin{array}{l}\text { Metodologia reflexiva, baseada } \\
\text { na indução (observação dos casos } \\
\text { particulares para a conclusão das } \\
\text { regularidades/regras). }\end{array}$ \\
\hline $\begin{array}{l}\text { Privilégio das habilidades } \\
\text { metalinguísticas. }\end{array}$ & $\begin{array}{l}\text { Trabalho paralelo com habilidades } \\
\text { metalinguísticas e epilinguísticas. }\end{array}$ \\
\hline
\end{tabular}




\begin{tabular}{|c|c|}
\hline $\begin{array}{l}\text { Ênfase nos conteúdos gramaticais } \\
\text { como objetos de ensino, abordados } \\
\text { isoladamente e em sequência mais ou } \\
\text { menos fixa. }\end{array}$ & $\begin{array}{l}\text { Enfase nos usos como objetos de } \\
\text { ensino (habilidades de leitura e } \\
\text { escrita), que remetem a vários outros } \\
\text { objetos de ensino (estruturais, textuais, } \\
\text { discursivos, normativos), apresentados } \\
\text { e retomados sempre que necessário. }\end{array}$ \\
\hline Centralidade na norma padrão. & Centralidade nos efeitos de sentido. \\
\hline $\begin{array}{l}\text { Ausência de relação com as especifi- } \\
\text { cidades dos gêneros, uma vez que a } \\
\text { análise é mais de cunho estrutural e, } \\
\text { quando normativa, desconsidera o } \\
\text { funcionamento desses gêneros nos } \\
\text { contextos de interação verbal. }\end{array}$ & $\begin{array}{l}\text { Fusão com o trabalho com os gêneros, } \\
\text { à medida que contempla justamente a } \\
\text { intersecção das condições de produção } \\
\text { dos textos e as escolhas linguísticas. }\end{array}$ \\
\hline $\begin{array}{l}\text { Unidades privilegiadas: a palavra, a } \\
\text { frase e o período. }\end{array}$ & Unidade privilegiada: o texto. \\
\hline $\begin{array}{l}\text { Preferência pelos exercícios estrutu- } \\
\text { rais, de identificação e classificação de } \\
\text { unidades/ funções morfossintáticas e } \\
\text { correção. }\end{array}$ & $\begin{array}{l}\text { Preferência por questões abertas e } \\
\text { atividades de pesquisa, que exigem } \\
\text { comparação e reflexão sobre a adequa- } \\
\text { ção e efeitos de sentido. }\end{array}$ \\
\hline
\end{tabular}

Fonte: SANTOS, RICHE e TEIXEIRA (2015, p. 76-77)

Nos PCN (BRASIL, 1998), a questão do uso linguístico (que se concretiza na prática da recepção e produção de textos) e a da reflexão sobre a língua (prática de análise linguística) encontram-se devidamente contempladas no eixo uso-reflexão-uso. Não obstante, a atual versão da BNCC (BRASIL, 2018) expande esse eixo para além da língua, ao incluir outras semioses. Por isso, esse documento reforça a ideia de que cabe ao professor de Língua Portuguesa trabalhar outras linguagens além da verbal. Afinal, cada vez mais, vivemos em um mundo mediado por elas. Notadamente, com o avanço tecnológico e os novos gêneros digitais, temos consumido cada vez mais textos que constroem seus sentidos por meio de mais de uma semiose: língua e som, língua e imagem, entre outras. Nesse sentido, a proficiência leitora depende também do reconhecimento das relações de sentido promovidas nesses textos. Ou seja, além das atividades de análise e reflexão linguística, cabe à escola promover atividades de análise e reflexão 
semiótica, em que os alunos são levados a estabelecer relações de sentido para elementos paralinguísticos e cinésicos nos textos orais, por exemplo, ou ainda a observar as categorias de figura/fundo, profundidade e foco, cor e intensidade, ritmo/movimento (entre outros), em um texto com plano de expressão imagético, por exemplo.

Ocorre que, infelizmente, o caráter mais simbólico e abstrato da língua, em oposição ao caráter aparentemente mais referencial de algumas outras semioses, como a imagem, fizeram-nos crer que sua recepção se daria de forma mais imediata e fácil, sem que fosse necessária a elaboração de uma metodologia de ensino. No entanto, esse é um pensamento deveras ingênuo, haja vista que a manipulação de sentidos parece funcionar melhor por meio dessas outras semioses. No que tange à imagem, sua semelhança com o real leva-nos a interpretar aquilo que vemos como a realidade mesma. Como ilustração, vejamos a transcrição da fala ${ }^{4}$ de um vídeo da senadora do PT Regina Souza, que supostamente estaria justificando a legalização do aborto no seguinte trecho: "a grávida, ela não pode, ela vai ficar nove meses na incerteza de como é que vai nascer essa criança. Se vai ter alguma doença, se vai nascer com rinite, sinusite...". O vídeo foi editado e depois compartilhado inúmeras vezes, tendo sido a senadora depreciada e achincalhada nas redes sociais. Nesse sentido, entendemos que os leitores, ao ouvirem e verem o material, atribuíram veracidade às informações veiculadas, muito embora elas tenham sido postas fora do contexto. $\mathrm{Na}$ verdade, a senadora se manifestava contrariamente à legalização do trabalho de gestantes em locais insalubres, uma mudança da CLT que havia sido implementada por meio de Medida Provisória no Governo do Presidente Michel Temer. Portanto, alguém mal-intencionado editou o vídeo e o associou a um diferente contexto.

É exatamente por esse motivo que a BNCC (BRASIL, 2018) traz à nossa reflexão a questão da pós-verdade. Hoje, as opiniões parecem importar mais do que os fatos e, pior, produzem-se factoides para sustentar opiniões e disseminar o ódio cotidianamente. Dessa forma, cabe à escola não apenas

\footnotetext{
${ }^{4}$ Disponível em: https://www.youtube.com/watch?v=kNGU52UgPbc - acesso em 20 de setembro de 2018.
} 
conscientizar o aluno sobre a importância de se verificar a procedência da informação, mas também levá-lo a refletir sobre a necessidade de agir com ética na produção desses textos. Muitos jovens hoje dominam os recursos tecnológicos que permitem a edição da imagem e do vídeo e utilizam-nos com imprudência e, às vezes, até de forma criminosa.

Para além dessa questão, no que tange à verificação da veracidade das informações e à ética na produção de textos multissemióticos, deve-se pensar que as outras semioses podem ser tão simbólicas quanto aquelas mediadas pela palavra. Os anúncios e campanhas publicitárias, por exemplo, visam à adesão de seus leitores, muitas vezes, por meio da construção de um ponto de vista. Em 2007, por exemplo, na França, circulou uma campanha publicitária de prevenção à transmissão do vírus HIV. Uma das peças da campanha, dirigida ao público homossexual feminino, trazia uma aranha negra em uma relação sexual com uma mulher branca, de vestido branco. Há uma outra versão dessa campanha, destinada ao público masculino, em que há um homem seminu deitado sobre um escorpião ${ }^{5}$. Nesse sentido, temos de entender que as duas campanhas materializam o papel homossexual através da aranha e do escorpião, que representam, respectivamente, o feminino ativo e o masculino passivo. No texto, a aranha e o escorpião, dois animais peçonhentos, são a materialização do próprio mal e representam o portador e transmissor do vírus HIV. Portanto, observamos que a construção de sentidos depende da análise dos diferentes símbolos que compõem a imagem e da relação entre eles, e essa é uma competência a ser desenvolvida na escola.

Por fim, é importante reforçar a questão da diversidade cultural, como já afirmamos previamente neste texto. Isto é, além da seleção de textos de diferentes gêneros e de múltiplas semioses, deve o professor de Língua Portuguesa selecionar textos que valorizem a cultura produzida por outros estratos sociais e/ou regiões do Brasil e do mundo. Afinal, só é possível superar uma visão estereotipada do mundo quando o vemos de diferentes perspectivas e olhares, em que a alteridade é respeitada e com-

\footnotetext{
${ }^{5}$ As duas imagens estão disponíveis no site: http://mktextrafarma.blogspot.com/2007/ Acesso em: 21 set.2018.
} 
preendida. Assim, o reconhecimento e a valorização da própria cultura (e da cultura do outro) devem fazer parte do cotidiano da escola. Como reflexão, finalizo esta seção com um fragmento de uma palestra da escritora nigeriana Chimamanda Ngozi Adichie (2010) ${ }^{6}$, em que ela reflete acerca do perigo de se ver o mundo sob uma única perspectiva (isto é, o olhar da cultura dominante):

Eu também fui uma escritora precoce, e quando eu comecei a escrever, aos sete anos, histórias a lápis com ilustrações em giz-de-cera que minha pobre mãe era obrigada a ler, eu redigia exatamente os mesmos tipos de história que eu vinha lendo: todos os meus personagens tinham olhos azuis, brincavam na neve, comiam maçãs e falavam sobre o tempo, quão bom era o fato de haver, finalmente, sol. No entanto, eu vivia na Nigéria e nunca havia saído de lá. Nós não tínhamos neve, comíamos mangas e nunca falávamos sobre o tempo, porque isso não era necessário. [...]

Isso demostra, eu penso, o quão impressionável e vulnerável eu era, particularmente quando criança, com as histórias que lia. Uma vez que todos os livros que lia continham personagens estrangeiros, eu me convenci de que os livros, por sua própria natureza, tinham de ter personagens estrangeiros e tinham de falar sobre coisas que eu não sabia identificar. Isso mudou quando eu descobri os autores africanos. Não havia muitos deles e eles não eram tão fáceis de achar quanto os livros estrangeiros.

\section{Exercícios}

1. Explique por que a prática de ensino deve centrar-se nas necessidades do sujeito da aprendizagem.

2. Por que devemos considerar o texto a unidade básica de ensino, e não os estratos linguísticos, como a letra/fonema, a sílaba, a palavra, o sintagma e a frase?

\footnotetext{
${ }^{6}$ Transcrição em inglês, disponível no site: http://lingualeo.com/pt/jungle/chimamanda-ngozi-adichie-the-danger-of-a-single-story-268285\#/page/1 - Acesso em 21/09/2018.
} 
3. O que é multiletramento e de que modo esse conceito se diferencia do termo letramento?

4. Por que, no desenvolvimento das habilidades de leitura e escrita, o aluno deve recorrer ao contexto de produção do discurso?

5. Que crítica é apontada quanto à produção artificial de textos? Cite estratégias que podem ser empregadas para evitar esse problema.

6. De que modo um modelo espiral de ensino de gramática, pautado em textos, diferencia-se de um modelo de listas?

7. Por que é importante trabalhar com diferentes semioses e abordar a diversidade cultural na seleção dos textos?

\section{Resumo}

No início deste capítulo, abordamos a questão do fracasso no ensino de Língua Portuguesa no Brasil. Como vimos, o ensino descontextualizado de gramática deixou de produzir os resultados esperados com a universalização da Educação Básica, quando as classes menos favorecidas passaram a ter amplo acesso ao espaço escolar. Por isso, tornou-se imperioso o desenvolvimento de novas metodologias de ensino, que visassem ao desenvolvimento das habilidades de leitura e escrita. Nesse processo, muito colaboraram as pesquisas científicas desenvolvidas na segunda metade do século XX, notadamente a Teoria Sócio-Interacionista e as teorias do letramento e do texto/discurso.

Em 1998, surgem os PCN de Língua Portuguesa, que representam um conjunto de diretrizes educacionais cuja principal finalidade é a de orientar as práticas pedagógicas de ensino de Língua Portuguesa no Brasil. Nessa perspectiva, o texto é considerado a unidade básica de ensino, sendo o maior objetivo da Língua Portuguesa o desenvolvimento da competência discursiva, alcançada por meio de práticas que levem à proficiência das quatros habilidades linguísticas, a saber: falar, escrever, escutar e ler.

Entende-se, portanto, que a aprendizagem das habilidades não se restringe ao processo de alfabetização. $\mathrm{Na}$ verdade, os alunos, ao longo de toda a vida escolar, vão se tornando mais hábeis tanto na 
recepção quanto na produção dos mais variados gêneros de texto. Daí, surge o conceito de letramento, que difere do termo alfabetização. Enquanto este se refere à aquisição da tecnologia do ler e do escrever, aquele está associado à apropriação dos gêneros de texto, isto é, a sua recepção e produção nas diferentes situações de produção do discurso.

Vimos que esse conceito, hoje, é visto sob uma abordagem mais lata. Fala-se não apenas em letramento, mas em multiletramentos, sobretudo na versão mais recente da BNCC (BRASIL, 2018). Nessa perspectiva, incluem-se as diferentes semioses, bem como os textos advindos de diferentes estratos culturais. Desse ponto de vista, vê-se que, no mundo em que vivemos, a proficiência de leitura requer a interpretação da imagem, do som, do movimento, do ritmo, entre outros, haja vista que grande parte dos textos contemporâneos são multissemióticos e produzem seus sentidos por intermédio de diferentes linguagens. Paralelamente, falamos da importância de se evitar um raciocínio reducionista quanto à esfera cultural. Nesse sentido, devemos valorizar tanto o cânone, quanto o marginal, o culto, o popular, a cultura de massa etc.

Por fim, também trouxemos reflexões sobre as práticas de leitura, escrita e de ensino de gramática. Por uma ótica de ensino pautado em gêneros textuais, a leitura deve extrapolar a interpretação/compreensão, ao dar ao aluno a oportunidade de dominar os aspectos estruturais, temáticos e estilísticos dos gêneros em estudo, bem como a de investigar questões de ordem contextual (como domínio discursivo, intencionalidade, relação autor-leitor, entre outros). Já a escrita deve oportunizar a autoria dos alunos, por meio de práticas que visem à circulação dos textos produzidos na escola, isto é, redigidos em circunstâncias reais, destinados para interlocutores também reais, para quem se deseja efetivamente transmitir alguma informação. A gramática, por sua vez, deve ser contextualizada e produtiva, de modo a permitir que o aluno observe seus efeitos de sentido e faça uso dos recursos gramaticais na própria produção de seu texto, com vistas à obtenção de seus objetivos comunicativos. 


\section{Referências}

ADICHIE, Chimamanda. N. The danger of a single story. 2010. Disponível em: http://lingualeo.com/pt/jungle/chimamanda-ngozi-adichie-the-danger-of-a-single-story-268285\#/ page/1. Acesso em: 21 set.2018.

ANSCOMBRE, Jean-Claude; DUCROT, Oswald. L'argumentation dans la langue. Liege Bruxelles: Pierre Mardaga, 1983.

ANTUNES, Irandé. Análise de textos. Fundamentos e práticas. São Paulo: Parábola, 2010.

BAZERMAN, Charles. Gênero, agência e escrita. São Paulo: Cortez, 2006.

BEZERRA, Maria Auxiliadora. Ensino de Língua Portuguesa e contextos teórico-metodológicos. In: DIONISIO, Ângela Paiva; MACHADO, Anna Raquel; BEZERRA, Maria Auxiliadora (Orgs.). Gêneros textuais É ensino. Rio de Janeiro: Lucerna, 2007, p. 37-46.

BRASIL. Secretaria de Ensino Fundamental. Parâmetros Curriculares Nacionais de Lingua Portuguesa. 30 e $4^{\circ}$ ciclos. Brasília: MEC, 1998.

BRASIL. Secretaria de Educação Básica. Diretrizes Curriculares Nacionais Gerais da Educação Básica. Brasília: MEC, SEB, DICEI, 2013.

BRASIL. Secretaria de Educação Básica. Base Nacional Comum Curricular. Brasília: MEC, SEB, 2018.

FERNANDES, Domingos. Avaliação alternativa: perspectivas teóricas e práticas de apoio. In: Futuro Congressos e Eventos (Ed.). Livro do $3^{\circ}$ Congresso Internacional sobre Avaliação da Educação. Curitiba: Futuro Eventos, 2005, p. 79-92.

KLEIMAN, Angela. (Org.). Os significados do letramento. Campinas: Mercado das Letras, 1995.

LOCKE, John. Ensaio acerca do entendimento humano. São Paulo: Nova Cultural, 2005.

MATTHIESSEN, Christian; THOMPSON, Sandra. The structure of discourse and 'subordination'. In: HAIMAN, John.; THOMPSON, Sandra. (Eds.). Clause combining in Grammar and discourse. Amsterdan: John Benjamins Publishing, 1988, p. 275-329.

SANTOS, Leonor W.; RICHE, Rosa Cuba; TEIXEIRA, Claudia Souza. Análise e produção de textos. São Paulo: Contexto, 2015.

SCHNEUWLY, Bernard; DOZ, Joaquim. (Orgs.). Gêneros orais e escritos na escola. Campinas: Mercado das Letras (2007).

SENADO FEDERAL. Constituição da República Federativa do Brasil. Brasília: SEP, 2015.

SOUZA, Jessé. A elite do atraso. Da escravidão à lava jato. Rio de Janeiro: Leya, 2017.

TRAVAGLIA, Luiz Carlos. Gramática e Interação: uma proposta para o ensino de gramática. 11. ed. São Paulo: Cortez, 2009.

VYGOTSKY, Leontiev. Pensamento e Linguagem. São Paulo: Martins Fontes, 1999. 


\section{FUNDAMENTOS DIDÁTICO-PEDAGÓGICOS DA LIINGUA PORTUGUESA: COMO ENSINAR?}

Ivo da Costa do Rosário (UFF)

\section{Objetivos}

Ao final deste capítulo, você deve ser capaz de compreender...

- por que a sequência didática é um instrumento eficaz para ajudar o professor a como ensinar;

- quais são as partes centrais de uma sequência didática e como dinamizá-las;

- por que o texto é considerado a unidade básica central das sequências didáticas, em uma perspectiva sociointeracional;

- a compatibilidade das sequências didáticas com outras propostas metodológicas de ensino de Língua Portuguesa.

Cabe à escola $[. .$.$] que cada aluno se torne capaz de interpretar dife-$ rentes textos que circulam socialmente, de assumir a palavra e, como cidadão, de produzir textos eficazes nas mais variadas situações.

(BRASIL, 1998, p. 19)

\section{Introdução}

Como ensinar? Sem dúvida, muitos docentes já se fizeram essa pergunta, que é crucial em todo processo de ensino-aprendizagem. Mesmo de forma intuitiva, sabemos que ensinar é muito mais que uma simples transmissão de informações. Afinal, a televisão, a internet, as conversas informais e todos os atos de comunicação humana informam, mas não necessariamente ensinam.

A questão de como ensinar tem atraído a atenção de muitos linguistas, pedagogos, professores e de demais profissionais da área de Educação. Afinal, o tão propalado fracasso escolar está muitas vezes associado a uma alegada "falta de didática" ou a algum defeito no campo metodológico. 
Após as reflexões apresentadas no capítulo anterior (sobre para quê, para quem e o que ensinar), este capítulo dedica-se a apresentar um instrumento de trabalho útil para o ensino de Língua Portuguesa. Assim, dá prosseguimento ao texto anterior e, de certa forma, finaliza a discussão ali travada.

Em primeiro lugar, deve-se reiterar a centralidade do texto no ensino de Língua Portuguesa, pautado em gêneros textuais. Esse trabalho com gêneros deve estar focado em leitura e produção de textos, sempre permeados pelas tarefas de interpretação e compreensão. Fatores estruturais, temáticos e estilísticos dos gêneros, aliados a questões de ordem contextual (como domínio discursivo, intencionalidade, relação autor-leitor, entre outros) são igualmente eleitos neste livro como pilares do ensino de língua materna.

Especificamente com relação à escrita, é fundamental oportunizar a autoria dos alunos, tendo em vista a produção de textos reais para interlocutores reais, extrapolando os muros da escola. Por sua vez, a gramática deve ser prioritariamente contextualizada e produtiva, de modo a permitir que o aluno sistematize e se aproprie de seus efeitos de sentido, instrumentalizando-a em prol de seus objetivos comunicativos.

Com base nessas premissas - pela visão de língua aqui delineada, pautada em uma perspectiva funcional e sociointeracionista baseada nos usos efetivos - é possível postular um mecanismo ou instrumento teórico-metodológico capaz de possibilitar uma real aprendizagem da Língua Portuguesa por parte dos nossos alunos.

Deve-se destacar que há, sem dúvida, múltiplos caminhos e estratégias possíveis para a condução das aulas de Língua Portuguesa em contextos escolares. Assim, é importante deixar claro que o encaminhamento aqui proposto não se singulariza; ao contrário, está imerso em uma pluralidade teórico-metodológica. Nesse grande emaranhado de possibilidades, elegemos as sequências didáticas (doravante $\mathrm{SD}$ ) como um caminho eficaz para um trabalho produtivo de ensino de Língua Portuguesa.

Inicialmente cabe definir o que é uma SD. Para isso, valemo-nos de Dolz, Noverraz e Schneuwly (2004, p. 97): "Uma 'sequência didática' é um conjunto de atividades escolares organizadas, de maneira sistemática, em 
torno de um gênero textual oral ou escrito". Assim, o ponto central de uma $\mathrm{SD}$ é o texto, que é eleito como ponto de partida e ponto de chegada de todo processo educativo em língua materna. Defendemos, portanto, que é por meio de práticas textuais que se alcança um dos objetivos centrais definidos pelo PCN de Língua Portuguesa:

O domínio da linguagem, como atividade discursiva e cognitiva, e o domínio da língua, como sistema simbólico utilizado de uma comunidade linguística, são condições de possibilidade de plena participação social. Pela linguagem os homens e as mulheres se comunicam, têm acesso à informação, expressam e defendem pontos de vista, partilham ou constroem visões de mundo, produzem cultura (BRASIL, 1998, p. 19).

A SD é um recurso metodológico que foi definido coletivamente pela "equipe de Didática de Línguas da Faculdade de Psicologia e Ciências da Educação da Universidade de Genebra - Suíça, para planejamento e elaboração de material didático para o ensino de gêneros textuais" (VARGAS; MAGALHÃES, 2011, p. 125). Desde então, esse instrumento vem sendo refinado e adaptado em vários países, com bons resultados no ensino de língua materna no Brasil.

Como fica bastante claro, uma SD tem o texto (na modalidade oral ou escrita) como unidade central de trabalho. Assim, esse recurso metodológico de ensino de Língua Portuguesa está fortemente associado com a visão de língua defendida nesta obra que, por sua vez, está ligada também aos Parâmetros Curriculares Nacionais e à Base Nacional Comum Curricular. A grande finalidade da SD é ajudar o aluno a ler e escrever com mais proficiência, o que, de forma inequívoca, está fundamentado nos gêneros textuais.

Apesar da aparente obviedade do que afirmamos, infelizmente essa não é a visão comumente cultivada, na prática, pelos autores de livros didáticos no Brasil. Marcuschi (2003, p. 21, grifos do autor), por exemplo, afirma:

Observando os LDP (livros didáticos de Língua Portuguesa) em geral, constata-se que poucos preocupam-se em explicitar a noção de língua com que operam. Contudo, uma breve análise revela imediatamente 
qual o conceito subentendido. Com poucas exceções, a maioria dos LDP trabalham regras (no estudo gramatical); identificam informações textuais (nos exercícios de compreensão) e produzem textos escritos (na atividade de redação). Há outras atividades, mas elas são incidentais no contexto geral do ensino de língua.

Reiteramos que a concepção teórica que sustenta a SD é uma noção de língua/gem compreendida como interação, calcada em aspectos sociais e funcionais. Esse aspecto deve ser considerado em grande medida, tendo em vista que essa premissa guia e governa toda proposta, em seus múltiplos desdobramentos.

Dolz, Noverraz e Schneuwly (2004, p. 114) defendem que "as sequências visam ao aperfeiçoamento das práticas de escrita e de produção oral e estão principalmente centradas na aquisição de procedimentos e de práticas. [...] Constituem um lugar de intersecção entre atividades de expressão e de estruturação".

As SD têm como grande foco, portanto, as práticas de escrita e de produção oral. Para isso, devem ser esquematizadas pelo professor por meio de princípios de progressão. Isso significa que diferentes gêneros, pertencentes a um mesmo grupo, podem ser trabalhados conjuntamente ou um mesmo gênero pode ser trabalhado em diferentes ciclos ou anos de escolaridade, com graus progressivos de complexidade. Nesse segundo caso, dá-se uma "progressão em espiral", em que são graduáveis tanto a complexidade dos conteúdos quanto as exigências quanto à correção e abrangência dos textos produzidos. O mais importante é que haja um encadeamento lógico do trabalho, com planejamento coerente.

Nesta breve introdução, apresentamos o conceito de língua adotado neste trabalho, ou seja, a visão sociointeracionista e funcional, bem como também definimos o conceito-chave de sequência didática. $\mathrm{Na}$ próxima seção do capítulo, exploraremos mais detalhadamente como se constitui uma sequência didática, em cada uma de suas partes. Em seguida, traçaremos algumas considerações gerais sobre as SD. Logo depois, apresentaremos um modelo de SD, permeado por alguns comentários analíticos. Por fim, 
encerramos o texto com algumas considerações finais, seguidas das referências bibliográficas utilizadas.

\section{Como se constitui uma sequência didática?}

No ambiente escolar, mesmo em contextos fortemente normativistas e pautados em gramáticas tradicionais, sem dúvida o texto também está presente, mesmo que seja para servir como pretexto para o estudo de gramática prescritiva. Em outras situações, o texto ganha maior importância, mas não chega a constituir um objeto sistemático de ensino, visto que carece de uma abordagem teórico-metodológica consistente. As SD suprem essa deficiência e vão além dos quadros delineados, ao se apresentarem como verdadeiros objetos de aprendizagem.

Dolz, Noverraz e Schneuwly (2004, p. 98) apresentam um esquema de sequência didática, que tem sido fortemente adotado e adaptado no Brasil. Esse esquema consiste nas seguintes etapas:

Esquema 1 - Esquema da sequência didática

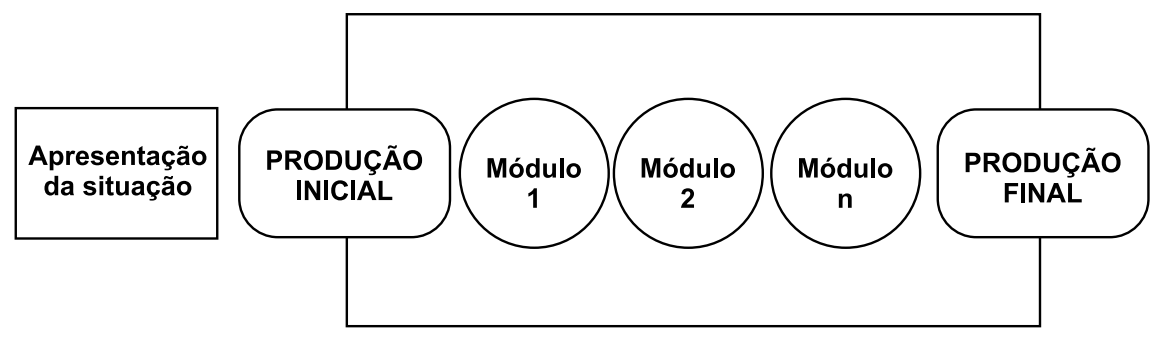

Fonte: Dolz, Noverraz e Schneuwly (2004, p. 98)

Segundo o Esquema 1, as SD apresentam quatro etapas básicas: a) apresentação da situação; b) produção inicial; c) módulos; d) produção final. Como facilmente se observa que todo o percurso de trabalho está pautado em um viés discursivo, visto que partimos do texto e chegamos a uma nova versão dele.

Vejamos como se caracteriza cada etapa de uma SD em mais detalhes: 


\section{a) Apresentação da situação}

Esta primeira etapa de uma SD visa a descrever de maneira detalhada como será a produção inicial, que é a etapa seguinte. Trata-se de uma etapa propedêutica, que deve estar fundamentada em um projeto bem definido de produção, no gênero oral ou escrito. $\mathrm{Na}$ apresentação da situação, é fundamental que o professor ponha em cena qual gênero será abordado na $\mathrm{SD}$, quem serão os interlocutores do texto produzido, como será o processo de produção (individual, coletivo ou outro). É nessa etapa também que o professor comenta as atividades que serão desenvolvidas, indica as áreas do conhecimento que serão abrangidas pela proposta, apresenta exemplares do gênero que será trabalhado e, em interação com os alunos, ajusta as próximas etapas.

\section{b) Produção inicial}

A produção inicial é fruto do encaminhamento dado à etapa anterior. Constitui-se como uma etapa em que o aluno (individualmente, em dupla ou em outra forma de organização) faz uma primeira tentativa de produzir um texto na ótica do gênero textual em foco. Para o professor, essa etapa é fundamental, visto que é por meio dessa primeira produção que o docente poderá avaliar tanto as capacidades já adquiridas pelos alunos quanto o conhecimento prévio do gênero e, ainda, ajustar as atividades seguintes. Assim, as etapas posteriores são fortemente balizadas e impactadas pela análise realizada pelo professor a partir da produção inicial, que é um verdadeiro termômetro para os encaminhamentos didáticos seguintes. É natural que essa primeira produção ainda não seja totalmente completa ou afinada com o gênero em todas as suas particularidades. Afinal, essa é apenas uma primeira tentativa de realizar o gênero. Nessa etapa, deve sobressair, portanto, a função reguladora da SD.

\section{c) Módulos}

Módulos são conjuntos de atividades ou exercícios que ajudarão os alunos a superar as dificuldades detectadas pelo professor na produção ini- 
cial. Devem envolver conjuntos de saberes diversos, trabalhados sempre de forma sistemática e em níveis crescentes de aprofundamento. O objetivo é fazer que o aluno angarie mais competências, a fim de produzir um texto final mais robusto e concatenado com os traços do gênero em foco. Todos os módulos devem trabalhar necessariamente os problemas que surgiram ao longo da primeira produção, ajudando os alunos a superá-los. Não há um número definido de módulos, pois são muitas variáveis em jogo. Também não há um tempo definido para que cada módulo seja trabalhado. Tudo depende, em grande medida, do desenvolvimento da turma, de seus avanços, de suas dificuldades, de seus interesses etc. Cada módulo deve estar focado em um problema particular, para que haja avanços. Nos módulos, o ideal é que o professor proponha atividades diversificadas.

Nesse contexto, Dolz, Noverraz e Schneuwly (2004, p. 105) afirmam que três categorias de atividades e de exercícios podem ser distintas: a) atividades de observação e de análise de textos (orais ou escritos, de textos completos ou partes); b) tarefas simplificadas de produção de textos (o aluno concentra-se mais em um aspecto preciso da elaboração de um texto - revisar uma parte, reorganizar o conteúdo, inserir uma parte que falta, elaborar refutações etc); c) elaboração de uma linguagem comum (para poder falar dos textos, comentá-los, criticá-los, melhorá-los etc). Deve haver a "capitalização de aquisições", o que consiste em oportunizar aos alunos que aprendam a falar sobre o gênero, por meio de uma linguagem técnica. Por fim, como as SD estão centradas nos gêneros textuais, é muito importante que haja atividades que contemplem as características composicionais, temáticas e estilísticas do gênero, bem como leitura, análise linguística e produção.

\section{d) Produção final}

A produção final é o momento em que o aluno põe em prática os conhecimentos adquiridos, por meio de um texto mais robusto. Ao professor cabe a realização de uma avaliação de caráter mais somativo. Esse tipo de avaliação possibilitará ao aluno verificar os objetivos já alcançados 
e os (ainda) não alcançados. Ao longo das etapas de revisão e reescrita, será possível que o aluno regule e controle seu próprio comportamento de produtor de textos, em permanente avaliação do seu progresso. Com referência à questão da reescrita, Dolz, Noverraz e Schneuwly (2004, p. 112) pontuam que o escritor "pode considerar seu texto como um objeto a ser retrabalhado, revisto, refeito, mesmo a ser descartado, até o momento em que o dá a seu destinatário. $\mathrm{O}$ texto permanece provisório enquanto estiver submetido a esse trabalho de reescrita”. Assim, ao se falar em produção final, para uma maior precisão, deveríamos falar em etapa de produções finais. Afinal, o texto deve estar sempre aberto a reformulações e aprimoramentos.

Em linhas gerais, essas são as partes principais da SD, tal como proposta pelos teóricos da Universidade de Genebra. Na próxima seção deste capítulo, focalizaremos alguns aspectos gerais das SD que merecem algum destaque.

\section{Algumas considerações gerais sobre o trabalho com SD}

Em primeiro lugar, deve-se frisar que o trabalho com SD rompe com uma visão distorcida e descontextualizada das práticas de leitura e produção de textos. De fato, o contexto de produção é uma variável fundamental em todo trabalho, e deve estar guiado por um planejamento coerente e coeso. Em outras palavras, não se deve propor aos alunos que produzam um texto "a partir do zero", mas dentro de uma concepção orgânica, com etapas bem definidas e delineadas.

Por meio do quadro a seguir, Dolz, Noverraz e Schneuwly (2004, p. 126) apresentam uma sugestão de como trabalhar diferentes gêneros textuais no ensino fundamental. A proposta consiste em abordar tanto gêneros da oralidade (os que estão com asterisco) quanto da escrita, em cinco "agrupamentos": narrar, relatar, argumentar, transmitir informaçôes e regular comportamentos, que guardam estreita relação com o que conhecemos pelo nome de sequências tipológicas ou discursivas. Os diversos gêneros estão distribuídos em quatro ciclos, que correspondem aos nove anos de escolaridade do ensino fundamental. Vejamos o quadro: 
Quadro 1 - Agrupamentos de gêneros

\begin{tabular}{|c|c|c|c|c|}
\hline \multirow{2}{*}{ AGRUPAMENTO } & \multicolumn{4}{|c|}{ CICLO } \\
\hline & $1^{\mathrm{a}}-2^{\mathrm{a}}$ & $3^{a}-4^{a}$ & $5^{\mathrm{a}}-6^{\mathrm{a}}$ & $7^{\mathrm{a}}-8^{\mathrm{a}}$ \\
\hline NARRAR & $\begin{array}{l}\text { 1. O livro para } \\
\text { completar }\end{array}$ & $\begin{array}{l}\text { 1. O conto } \\
\text { maravilhoso } \\
\text { 2. A narrativa } \\
\text { de aventura }\end{array}$ & $\begin{array}{l}\text { 1. O conto do } \\
\text { porquê e do } \\
\text { como } \\
\text { 2. A narrativa } \\
\text { de aventura }\end{array}$ & $\begin{array}{l}\text { 1. A paródia de } \\
\text { conto } \\
\text { 2. A narrativa } \\
\text { de ficção } \\
\text { cientíica } \\
\text { 3. A novela } \\
\text { fantástica }\end{array}$ \\
\hline RELATAR & $\begin{array}{l}\text { 1. O relato de } \\
\text { experiência } \\
\text { vivida* } \\
\text { (Apresentação } \\
\text { em áudio) }\end{array}$ & $\begin{array}{l}\text { 1. O testemunho } \\
\text { de uma } \\
\text { experiência } \\
\text { vivida }\end{array}$ & 1. A notícia & $\begin{array}{l}\text { 1. A nota } \\
\text { biográfica } \\
\text { 2. A reportagem } \\
\text { radiofônica* }\end{array}$ \\
\hline ARGUMENTAR & $\begin{array}{l}\text { 1. a carta de } \\
\text { solicitação }\end{array}$ & $\begin{array}{l}\text { 1. A carta de } \\
\text { resposta ao } \\
\text { leitor } \\
\text { 2. O debate } \\
\text { regrado }\end{array}$ & $\begin{array}{l}\text { 1. A carta de } \\
\text { leitor } \\
\text { 2. A } \\
\text { apresentação de } \\
\text { um romance* }\end{array}$ & $\begin{array}{l}\text { 1. A repetição } \\
\text { 2. A nota crítica } \\
\text { de leitura } \\
\text { 3. O ponto de } \\
\text { vista } \\
\text { 4. O debate } \\
\text { público* }\end{array}$ \\
\hline $\begin{array}{l}\text { TRANSMITIR } \\
\text { CONHECIMENTOS }\end{array}$ & $\begin{array}{l}\text { 1. Como } \\
\text { funciona? } \\
\text { (apresentação } \\
\text { de um } \\
\text { brinquedo e seu } \\
\text { funcionamento) }\end{array}$ & $\begin{array}{l}\text { 1. O artigo } \\
\text { enciclopédico } \\
\text { 2. A entrevista } \\
\text { radiofônica }\end{array}$ & $\begin{array}{l}\text { 1. A exposição } \\
\text { escrita } \\
\text { 2. A nota de } \\
\text { sintese para } \\
\text { aprender } \\
\text { 3. A exposição } \\
\text { oral* }\end{array}$ & $\begin{array}{l}\text { 1. A } \\
\text { apresentação de } \\
\text { documentos } \\
\text { 2. O relato } \\
\text { cientifico } \\
\text { 3. A entrevista } \\
\text { radiofônica* }\end{array}$ \\
\hline \multirow[t]{2}{*}{$\begin{array}{l}\text { REGULAR } \\
\text { COMPORTAMENTOS }\end{array}$} & $\begin{array}{l}\text { 1. A receita de } \\
\text { cozinha* } \\
\text { (apresentação } \\
\text { em áudio) }\end{array}$ & $\begin{array}{l}\text { 1. A descrição } \\
\text { de um } \\
\text { itinerário* }\end{array}$ & $\begin{array}{l}\text { 1. As regras do } \\
\text { jogo }\end{array}$ & \\
\hline & $\begin{array}{l}5 \text { sequências } \\
\text { (sendo } 2 \text { orais) }\end{array}$ & $\begin{array}{l}8 \text { sequências } \\
\text { (sendo } 3 \text { orais) }\end{array}$ & $\begin{array}{l}9 \text { sequências } \\
\text { (sendo } 2 \text { orais) }\end{array}$ & $\begin{array}{l}13 \text { sequências } \\
\text { (sendo } 4 \text { orais) }\end{array}$ \\
\hline
\end{tabular}

Fonte: Dolz, Noverraz e Schneuwly (2004, p. 126)

Se aplicada ao Ensino Fundamental, a proposta consignada nesse quadro oportuniza aos alunos que eles tenham acesso a diferentes gêneros textuais, tanto da escrita quanto da oralidade, associados a diferentes sequências tipológicas, envolvendo o narrar, o argumentar, o descrever, o expor e o relatar. Assim, é uma proposta ousada e abrangente, que naturalmente também poderia ser aplicada a outras etapas da Educação Básica. Deve-se deixar bem claro, entretanto, que esse quadro apenas sugere uma organização de trabalho. Isso significa que o professor deve se sentir autônomo para propor outros itinerários que atendam melhor aos seus objetivos e às características do seu alunado. 
Com relação à produção de textos propriamente dita, Dolz, Noverraz e Schneuwly (2004,p. 104) apresentam quatro níveis, baseados na Psicologia da Linguagem. Sintetizamo-los aqui:

1) Representação da situação de comunicação (destinatário do texto, finalidade visada, posição como autor ou locutor)

2) Elaboração dos conteúdos (técnicas para buscar, elaborar ou criar conteúdos - discussões, debates, tomada de notas, busca em outras matérias etc.)

3) Planejamento do texto (estruturar o texto de acordo com um plano)

4) Realização do texto (meios para escrever o texto - vocabulário apropriado, organizadores textuais, tempos verbais etc.)

Logo, há grande sistematicidade no processo de produção de textos, sempre calcado em um planejamento que busca envolver todos os aspectos fundamentais na realização dos gêneros. Não há espaço, portanto, para espontaneísmos, como infelizmente ainda vemos em algumas práticas escolares em que os alunos são orientados a escrever textos, sem clareza sobre seus objetivos, destinatários, funções sociais etc.

Outro aspecto fundamental diz respeito à avaliação. Não é justo ser avaliado por meio de critérios obscuros ou desconhecidos pelos alunos. Uma avaliação plenamente subjetiva, sem critérios explícitos, é inadmissível. Além disso, como não poderia ser diferente, todo processo de avaliação precisa estar fundamentado nos elementos efetivamente trabalhados ao longo das aulas, sem "pegadinhas" e sem subjetivismos.

Dolz, Noverraz e Schneuwly (2004, p. 104) apresentam um conceito muito importante para o tema que estamos discutindo. Trata-se da noção de modularidade:

A modularidade é um princípio geral no uso das sequências didáticas. O procedimento deseja pôr em relevo os processos de observação e de descoberta. Ele distancia-se de uma abordagem 'naturalista', segundo a qual é suficiente 'fazer' para provocar a emergência de uma nova 
capacidade. O procedimento evita uma abordagem 'impressionista' da visitação. Ao contrário, este se inscreve numa perspectiva construtivista, interacionista e social que supõe a realização de atividades intencionais, estruturadas e intensivas que devem adaptar-se às necessidades particulares dos diferentes grupos de aprendizes.

Como podemos observar, a modularidade rompe com os espontaneísmos adotados por algumas escolas e educadores no trabalho de produção de textos. Dito em outras palavras, não é suficiente que simplesmente o aluno escreva, escreva e escreva para que passe a escrever melhor. É evidente que a frequência é importante, mas sem a intervenção de um par competente e sem a propositura de atividades didáticas cuidadosamente planejadas, será muito difícil que o aluno consiga ser leitor e produtor de textos cada vez mais proficiente. Novas capacidades, assim, surgem de um trabalho profissional, consistente e fundamentado teoricamente por parte do professor, que sempre deverá ter em conta as particularidades de sua turma e de seus alunos. Em síntese, é impossível aferir bons resultados quando se aplicam propostas e abordagens mal construídas ou totalmente homogêneas para um público heterogeneamente diversificado.

Com relação ao ponto específico da adaptação das SD às necessidades dos alunos, Dolz, Noverraz e Schneuwly (2004, p. 111) lembram que, da parte do professor, deve-se

[...] analisar as produções dos alunos em função dos objetivos da sequência e das características do gênero; escolher as atividades indispensáveis para a realização da continuidade da sequência; prever e elaborar, para os casos de insucesso, um trabalho mais profundo e intervenções diferenciadas no que diz respeito às dimensões mais problemáticas.

Logo, fica claro que o trabalho com SD não permite a aplicação de receitas prontas ou fórmulas inflexíveis. Em outras palavras, não é possível que uma mesma SD seja aplicada a diferentes turmas da mesma forma. Afinal, cada turma é formada por alunos distintos, com particularidades e necessidades igualmente diversas. Isso deve levar o professor a perseguir objetivos diferentes, selecionar e elaborar atividades distintas e também planejar intervenções diferenciadas para a sua realidade imediata. 
Até esse momento, o leitor pode estar se questionando se a gramática encontra espaço nessa perspectiva de trabalho, visto que todo foco está na questão do texto propriamente dito. Nossa resposta é sim. De fato, a gramática tem seu devido espaço na perspectiva de um trabalho com SD. Dolz, Noverraz e Schneuwly (2004, p. 115-116) afirmam o seguinte:

No plano da sintaxe, as seguintes dificuldades aparecem mais frequentemente nos textos dos alunos: utilização de frases incompletas; falta de variedade na construção das frases; utilização de coordenação mais que da subordinação; pontuação insuficiente. Essas inabilidades, frequentemente resultantes de interferências entre sintaxe do oral e sintaxe da escrita, indicam também uma dificuldade de ordem cognitiva para hierarquizar elementos. [...] O domínio de uma sintaxe mais elaborada não está ligado a um gênero preciso. Ele passa pela compreensão e pela apropriação das regras gerais que dizem respeito à organização da frase e necessita de conhecimentos explícitos sobre o funcionamento da língua nesse nível. Trata-se, portanto, de desenvolver nos alunos capacidades de análise que lhes permitam melhorar esses conhecimentos. Para tanto, é essencial reservar tempo para um ensino específico de gramática, no qual o objeto principal das tarefas de observação e de manipulação é o funcionamento da língua.

Com essas palavras, por um lado, os autores supracitados defendem uma visão mais contextualizada da gramática, voltada para as necessidades de aprimoramento de estruturas textuais. Essa visão, aliás, é a que está consubstanciada nos Parâmetros Curriculares Nacionais e também costuma ser o discurso vigente dos teóricos filiados à Linguística Aplicada e a outras vertentes que se debruçam sobre o ensino. Por outro lado, os autores não negam a relevância de um domínio da sintaxe voltado para o funcionamento da língua, não necessariamente atrelado a um gênero específico. Assim, a apropriação de regras, a sistematização da metalinguagem gramatical e o conhecimento de formas canônicas também devem encontrar espaço nas chamadas SD. Rosário (2016, p. 53) também aborda esse aspecto: “A gramática normativa pode ser uma aliada importante na proposição de um ensino produtivo de Língua Portuguesa, desde que tomada como ponto de partida, 
e não como ponto de chegada”. De fato, a gramática normativa deve ser contemplada, mas não deve ser vista como um fim em si mesma, naturalmente.

A mesma orientação aplica-se à questão da ortografia. Um levantamento dos desvios ortográficos pode ser um importante instrumento para o trabalho em sala de aula. Em hipótese alguma esses erros devem ser ignorados ou sobrelevados. É importante que o professor encontre a justa medida para interferir positivamente, de forma a investir no que é prioritário tanto para os alunos em geral quanto para alunos individualmente ou em grupos. Deve-se destacar que esse trabalho de "higienização" do texto precisa ser levado a cabo especialmente na versão final da produção escrita e pode ser feito de diversas formas, como troca de textos entre alunos, por exemplo. Por fim, deve-se destacar que, ao longo das SD, é importante que os alunos tenham dicionários, quadros de conjugação de verbos, manuais de ortografia, gramáticas e outros instrumentos à sua disposição, cujo acesso hoje é facilitado por meio de aplicativos e bases digitais.

Após apresentarmos algumas questões gerais e particulares sobre o tema, na próxima seção, analisaremos brevemente um modelo possível de como dinamizar uma SD na prática, a partir de um modelo.

\section{Um exemplo comentado de SD}

Felizmente existem muitos materiais de qualidade produzidos no Brasil sob a ótica das SD. Essas propostas ora tomam a visão dos autores na íntegra, ora traduzem-se para nossa realidade nacional com algumas adaptações.

Neste capítulo, exploraremos a SD organizada por Suzana Lima Vargas e Luciane Manera Magalhães, professoras adjuntas da Faculdade de Educação da Universidade Federal de Juiz de Fora, com pequenas adaptações. Trata-se de uma SD baseada em torno do gênero tirinha ${ }^{1}$, desenvolvida

\footnotetext{
${ }^{1} \mathrm{O}$ trabalho de Vargas e Magalhães (2011), na íntegra, pode ser consultado em http://www. uff.br/revistaedufoco/files/2012/08/Texto-05.pdf (Acesso em 2 out.2018). Neste capítulo, transcrevemos os quadros que são extraídos das páginas 130 a 134 do artigo supracitado (com pequenas adaptações).
} 
e aplicada em turma de alunos do $2^{\circ}$ ano do ensino fundamental de uma escola pública da região onde as pesquisadoras atuam profissionalmente.

A proposta organizada por Vargas e Magalhães (2011) é particularmente interessante e abrangente porque organiza cada etapa de uma SD em três pontos: objetivos, atividades e materiais. Vejamos como está organizada a primeira etapa da SD, que consiste na apresentação da situação:

Quadro 2 - Apresentação da situação

\begin{tabular}{|c|c|c|}
\hline \multicolumn{3}{|c|}{ APRESENTAÇÃO DA SITUAÇÃO } \\
\hline OBJETIVOS & ATIVIDADES & MATERIAIS \\
\hline $\begin{array}{l}\text { * Compreender } \\
\text { o projeto } \\
\text { com o gênero } \\
\text { tirinhas; } \\
\text { * Familiarizar-se } \\
\text { com os } \\
\text { elementos } \\
\text { básicos da } \\
\text { estrutura } \\
\text { composicional } \\
\text { das tirinhas. }\end{array}$ & $\begin{array}{l}\text { * Compartilhar com os alunos as atividades } \\
\text { que serão realizadas no projeto (leitura, } \\
\text { análise linguística e produção textual); } \\
\text { * Disponibilizar diversas revistas de HQ } \\
\text { para manusearem o suporte e lerem as } \\
\text { tirinhas do final da revista; } \\
\text { * Destacar que as tirinhas podem ser lidas } \\
\text { de forma independente, sem qualquer } \\
\text { relação com as histórias da revista; } \\
\text { * Comparar o formato menor e limitado } \\
\text { das tirinhas de final de revista com o das } \\
\text { outras histórias mais longas; } \\
\text { * Sensibilizar os alunos quanto à presença } \\
\text { do humor expresso nas tiras; } \\
\text { * Conversar sobre os personagens } \\
\text { principais da tirinha e seu autor; } \\
\text { * Discutir os elementos básicos do gênero } \\
\text { tirinhas (relações entre linguagem visual } \\
\text { e verbal); } \\
\text { * Solicitar que elejam o meio de divulgação } \\
\text { das tirinhas que serão elaboradas ao } \\
\text { término da SD } \\
\text { (exposição em murais da escola, } \\
\text { organização de um álbum de tirinhas ou } \\
\text { concurso de tirinhas). }\end{array}$ & $\begin{array}{l}\text { * Revistas em } \\
\text { quadrinhos; } \\
\text { * Transparência, } \\
\text { slide ou } \\
\text { cartaz com os } \\
\text { personagens } \\
\text { principais e o } \\
\text { autor; } \\
\text { * Transparência, } \\
\text { slide ou } \\
\text { impresso com } \\
\text { tirinhas. }\end{array}$ \\
\hline
\end{tabular}

Fonte: Vargas (2011, p. 130-134). Adaptado

$\mathrm{Na}$ apresentação da situação proposta, objetiva-se que os alunos conheçam o gênero, especialmente com relação à sua estrutura composicional. 
Para isso, as atividades partem de um importante diálogo entre docente e discentes acerca de todo trabalho que será desenvolvido. Alguns aspectos precisam ser destacados nessa parte da SD: a) o contato com textos diversos representativos do gênero; b) a discussão sobre usos sociais do gênero; c) a decisão quanto à divulgação dos resultados finais.

O contato com diversos exemplares do gênero possibilita ao aluno perceber e reconhecer com mais clareza os seus aspectos e traços principais. Além disso, a diversidade de exemplares permite também o reconhecimento de que um mesmo gênero pode ser efetivado de formas diversas. A questão dos usos sociais, por sua vez, permite a conclusão de que os textos circulam socialmente, ou seja, cumprem papéis sociais. Por fim, a divulgação dos resultados finais assegura aos alunos a certeza de que os textos não serão produzidos apenas para receberem nota e serem descartados em seguida. Ao contrário, cumprirão sua função social.

Logo em seguida, vem a etapa da produção inicial. Como o gênero em foco é tirinha, a proposta é que os alunos produzam um texto representativo desse gênero e que, logo em seguida, a analisem com os colegas de turma. Vale destacar que essa etapa, segundo a proposta em foco, já conta com uma primeira avaliação. Vejamos:

Quadro 3-Produção inicial

\begin{tabular}{|c|c|c|}
\hline \multicolumn{3}{|c|}{ PRODUÇÃO INICIAL } \\
\hline OBJETIVOS & ATIVIDADES & MATERIAIS \\
\hline $\begin{array}{l}\text { * Produzir } \\
\text { uma tirinha; } \\
\text { * Analisar a } \\
\text { tirinha dos } \\
\text { colegas. }\end{array}$ & $\begin{array}{l}\text { * Leitura individual de } \\
\text { tirinhas; } \\
\text { * Produzir } \\
\text { individualmente uma } \\
\text { tirinha; } \\
\text { * Observação guiada } \\
\text { das tirinhas da } \\
\text { turma. }\end{array}$ & $\begin{array}{l}\text { * Revistas em quadrinhos; } \\
\text { * Atividade impressa com uma } \\
\text { sequência de três quadros dispostos } \\
\text { verticalmente para produção textual; } \\
\text { * Ficha de avaliação da tirinha } \\
\text { (A produção é uma tirinha? } \\
\text { Os desenhos e os textos estão } \\
\text { relacionados? Os três quadros têm } \\
\text { uma sequência lógica? O desfecho é } \\
\text { inesperado?). }\end{array}$ \\
\hline
\end{tabular}

Fonte: Vargas (2011, p. 130-134). Adaptado 
Logo em seguida, entramos na fase dos módulos, que naturalmente estão associados de forma muito íntima ao gênero textual tirinha. Assim, Vargas e Magalhães (2011) propõem cinco módulos, que são intitulados: a) sequência lógico-temporal; b) onomatopeias; c) balões; d) metáforas visuais; e) figuras cinéticas.

O primeiro módulo está centrado na questão da sequência lógico-temporal das tirinhas, que se dá entre um quadrinho e outro. Nesse módulo são trabalhados a importância da disposição dos quadrinhos, o tipo de leitura que se faz com relação a esse gênero, o tipo de narrativa normalmente focalizado pelas tirinhas, entre outros aspectos.

Quadro 4-Módulo 1 - Sequência lógico-temporal

\begin{tabular}{|c|c|c|}
\hline \multicolumn{3}{|c|}{ MÓDULO 1 - SEQUÊNCIA LÓGICO-TEMPORAL } \\
\hline OBJETIVOS & ATIVIDADES & MATERIAIS \\
\hline $\begin{array}{l}\text { * Compreender } \\
\text { a sequência } \\
\text { lógico- } \\
\text { temporal } \\
\text { característica } \\
\text { das tirinhas; } \\
\text { * Inferir a } \\
\text { sucessão } \\
\text { rápida de } \\
\text { acontecimentos } \\
\text { entre um } \\
\text { quadrinho e } \\
\text { outro. }\end{array}$ & $\begin{array}{l}\text { * Demonstrar que o tempo de leitura } \\
\text { das tirinhas é rápido devido ao número } \\
\text { reduzido de quadrinhos e de trechos } \\
\text { escritos; } \\
\text { * Explicar aos alunos a importância } \\
\text { da disposição dos quadrinhos para a } \\
\text { construção do sentido da narrativa } \\
\text { expressa na tirinha; } \\
\text { * Distribuir os quadrinhos de uma } \\
\text { tirinha para que, em dupla ou em } \\
\text { pequenos grupos, descubram qual é a } \\
\text { sequência lógico-temporal; } \\
\text { * Início da construção de uma lista } \\
\text { de constatações com as reflexões } \\
\text { realizadas sobre a sequência } \\
\text { lógico-temporal. }\end{array}$ & $\begin{array}{l}\text { *Tirinhas } \\
\text { ampliadas } \\
\text { para observar } \\
\text { e montar } \\
\text { conforme a } \\
\text { sequência } \\
\text { lógico- } \\
\text { temporal; } \\
\text { * Vários } \\
\text { conjuntos com } \\
\text { três quadrinhos } \\
\text { recortados e } \\
\text { desordenados } \\
\text { para a } \\
\text { montagem } \\
\text { das tirinhas, } \\
\text { respeitando a } \\
\text { linearidade. }\end{array}$ \\
\hline
\end{tabular}

Fonte: Vargas (2011, p. 130-134). Adaptado 
No módulo 2, trabalham-se as onomatopeias, que são recursos muito comuns em tirinhas, na função de cumprir diferentes funções representacionais. As atividades propostas giram em torno do reconhecimento, mas também da criação desses elementos, de forma lúdica e atraente para os alunos.

Quadro 5-Módulo 2 - Onomatopeias

\begin{tabular}{|c|c|c|}
\hline \multicolumn{3}{|c|}{ MÓDULO 2 - ONOMATOPEIAS } \\
\hline OBJETIVOS & ATIVIDADES & MATERIAIS \\
\hline $\begin{array}{l}\text { * Identificar as } \\
\text { onomatopeias } \\
\text { mais frequentes } \\
\text { nas tirinhas; } \\
\text { * Compreender que } \\
\text { as onomatopeias } \\
\text { complementam e } \\
\text { enfatizam as ações } \\
\text { dos personagens; } \\
\text { * Relacionar as } \\
\text { onomatopeias } \\
\text { com as suas } \\
\text { funções } \\
\text { representacionais. }\end{array}$ & $\begin{array}{l}\text { * Leitura de diversas tirinhas } \\
\text { para identificação e reflexão } \\
\text { a respeito do uso de } \\
\text { onomatopeias; } \\
\text { * Criação de onomatopeias a } \\
\text { partir da observação dos sons } \\
\text { produzidos por alguns objetos } \\
\text { e animais; } \\
\text { * Brincadeira de adivinha para } \\
\text { imitação de sons representados } \\
\text { nas onomatopeias; } \\
\text { * Complementação da lista de } \\
\text { constatações confeccionada no } \\
\text { módulo anterior. }\end{array}$ & $\begin{array}{l}\text { * Revistas em } \\
\text { quadrinhos e tirinhas } \\
\text { para leitura; } \\
\text { * Bandeja com } \\
\text { divisões para dispor } \\
\text { os diferentes tipos de } \\
\text { onomatopeias; } \\
\text { * Jogo de pareamento } \\
\text { com dois conjuntos } \\
\text { de fichas: } \\
\text { 1ª onomatopeias; } \\
\text { 2a) imitação; } \\
\text { * Cartaz da lista de } \\
\text { constatações. }\end{array}$ \\
\hline
\end{tabular}

Fonte: Vargas (2011, p. 130-134). Adaptado

O módulo 3 está focado na questão dos balões, que são recursos adotados para a expressão de diálogos entre as personagens das tirinhas. Nesse módulo, são trabalhados também os diferentes tipos de balões utilizados no gênero, as diversas fontes (tipos de letra e tamanhos) etc. 
Quadro 6-Módulo 3-Balões

\begin{tabular}{|c|c|c|}
\hline \multicolumn{3}{|c|}{ MÓDULO 3 - BALÕES } \\
\hline OBJETIVOS & ATIVIDADES & MATERIAIS \\
\hline $\begin{array}{l}\text { * Diferenciar } \\
\text { os tipos de } \\
\text { balões mais } \\
\text { frequentes } \\
\text { e suas } \\
\text { respectivas } \\
\text { funções nas } \\
\text { tirinhas; } \\
\text { * Escrever } \\
\text { diálogos, } \\
\text { pensamentos } \\
\text { ou } \\
\text { onomatopeias } \\
\text { nos diferentes } \\
\text { tipos de } \\
\text { balões. }\end{array}$ & $\begin{array}{l}\text { * Leitura de diversas tirinhas para } \\
\text { reconhecimento dos tipos de } \\
\text { balões; } \\
\text { * Analisar as diferentes formas } \\
\text { de balões presentes nas tirinhas, } \\
\text { destacando que as variações no } \\
\text { contorno indicam a situação da } \\
\text { fala dos personagens (sussurro, } \\
\text { gritos, conversa ao telefone, sonhos, } \\
\text { pensamentos); } \\
\text { * Escolher balões em branco, com } \\
\text { diferentes formas, para colagem nas } \\
\text { tirinhas, conforme as expressões } \\
\text { faciais dos personagens, em duplas } \\
\text { ou grupos; } \\
\text { * Escrita nos balões colados nas } \\
\text { tirinhas; } \\
\text { * Acrescentar na lista de } \\
\text { constatações os conhecimentos } \\
\text { construídos a respeito das formas } \\
\text { de balão. }\end{array}$ & 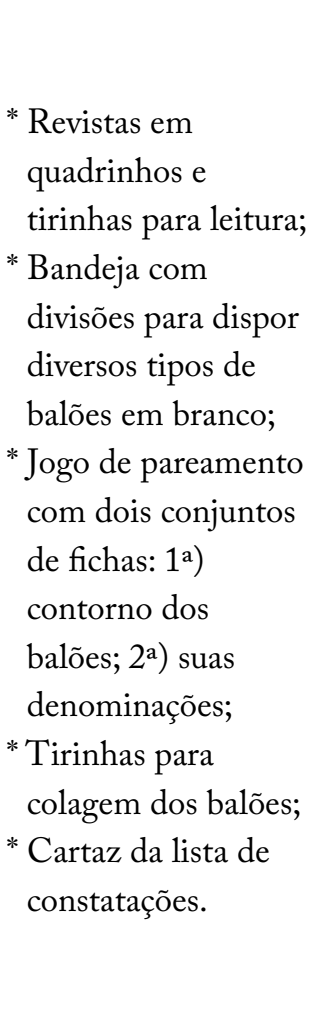 \\
\hline
\end{tabular}

Fonte: Vargas (2011, p. 130-134). Adaptado

No módulo 4, propõe-se um trabalho com metáforas visuais. A inter-relação entre imagens, metáforas visuais e textos verbais é a fórmula para uma tirinha alcançar seu propósito comunicativo. Paixão, canto, ideia, raiva e outras noções podem ser comunicadas por meio de metáforas visuais, o que também se abre a processos criativos por parte dos alunos. 
Quadro 7-Módulo 4-Metáforas visuais

\begin{tabular}{|c|c|c|}
\hline \multicolumn{3}{|c|}{ MÓDULO 4 - METÁFORAS VISUAIS } \\
\hline OBJETIVOS & ATIVIDADES & MATERIAIS \\
\hline $\begin{array}{l}\text { * Reconhecer as } \\
\text { metáforas visuais } \\
\text { mais frequentes nas } \\
\text { tirinhas; } \\
\text { * Compreender como } \\
\text { a relação entre as } \\
\text { imagens, a metáfora } \\
\text { visual e o texto } \\
\text { verbal contribui } \\
\text { para a construção da } \\
\text { coerência da tirinha. }\end{array}$ & $\begin{array}{l}\text { * Leitura de } \\
\text { diversas tirinhas } \\
\text { para que analisem } \\
\text { as metáforas } \\
\text { visuais; } \\
\text { * Selecionar } \\
\text { metáforas visuais } \\
\text { para incluir em } \\
\text { uma tirinha. }\end{array}$ & $\begin{array}{l}\text { * Revistas em quadrinhos e } \\
\text { tirinhas para leitura; } \\
\text { * Exercício com diversos } \\
\text { quadrinhos com metáforas } \\
\text { visuais para os alunos } \\
\text { interpretarem seu significado; } \\
\text { * Cartela com metáforas } \\
\text { visuais para recortá-las } \\
\text { ou desenhá-las na tirinha } \\
\text { (ideia, paixão, canto, palavras } \\
\text { agressivas); } \\
\text { * Cartaz da lista de } \\
\text { constatações. }\end{array}$ \\
\hline
\end{tabular}

Fonte: Vargas (2011, p. 130-134). Adaptado

Por fim, o módulo 5 trabalha a questão das figuras cinéticas, que estão muito fortemente associadas a ideias ou sentimentos dos personagens. Nesse módulo, inclui-se leitura de gráficos e imagens, por exemplo:

Quadro 8-Módulo 5 - Figuras cinéticas

\begin{tabular}{|c|c|c|}
\hline \multicolumn{3}{|c|}{ MÓDULO 5 - FIGURAS CINÉTICAS } \\
\hline OBJETIVOS & ATIVIDADES & MATERIAIS \\
\hline $\begin{array}{l}\text { * Identificar as ideias } \\
\text { ou sentimentos dos } \\
\text { personagens expressos } \\
\text { nas figuras cinéticas; } \\
\text { * Reconhecer os sinais } \\
\text { gráficos e imagens } \\
\text { usados para indicar } \\
\text { os movimentos dos } \\
\text { personagens por meio } \\
\text { de figuras cinéticas. }\end{array}$ & $\begin{array}{l}\text { * Leitura de tirinhas } \\
\text { que usam as figuras } \\
\text { cinéticas; } \\
\text { * Preencher quadros } \\
\text { retirados de HQ } \\
\text { com figuras cinéticas } \\
\text { conforme o contexto: } \\
\text { esforço físico, } \\
\text { gestos agressivos; } \\
\text { movimentos, } \\
\text { impactos... }\end{array}$ & $\begin{array}{l}\text { * Revistas em } \\
\text { quadrinhos e tirinhas } \\
\text { para leitura; } \\
\text { * Atividade com uma } \\
\text { tirinha com espaço } \\
\text { para criação de figuras } \\
\text { cinéticas por parte dos } \\
\text { alunos; } \\
\text { * Cartaz da lista de } \\
\text { constatações. }\end{array}$ \\
\hline
\end{tabular}

Fonte: Vargas (2011, p. 130-134). Adaptado 
Após os módulos apresentados, chega-se à última etapa da SD, que consiste na produção final. Espera-se, ao chegar a esse ponto, que os alunos sejam capazes de construir tirinhas de forma mais criativa, autônoma e autoral. Após percorrer as diversas tarefas propostas nos módulos, requer-se que os alunos também consigam explicitar as principais características do gênero. Como se trata de uma etapa final, deve-se acrescentar que há avaliação formal. Vejamos:

Quadro 9- Produção final

\begin{tabular}{|c|c|c|}
\hline \multicolumn{3}{|c|}{ PRODUÇÃO FINAL } \\
\hline OBJETIVOS & ATIVIDADES & MATERIAIS \\
\hline $\begin{array}{l}\text { * Produzir } \\
\text { uma tirinha } \\
\text { para a } \\
\text { finalização } \\
\text { do projeto; } \\
\text { * Reler e } \\
\text { revisar a } \\
\text { tirinha }\end{array}$ & $\begin{array}{l}\text { * Solicitar aos alunos que elaborem uma } \\
\text { tirinha para fazer parte da atividade final } \\
\text { que foi escolhida por eles na apresentação } \\
\text { da situação (exposição? concurso?); } \\
\text { * Orientar a produção da tirinha com } \\
\text { questionamentos acerca dos conhecimentos } \\
\text { já adquiridos: onde acontece, com quem, se } \\
\text { há diálogos, presença de humor, desfecho } \\
\text { inesperado; } \\
\text { * Trocar as tirinhas com seus pares para que } \\
\text { possam ser lidas e analisadas conforme a } \\
\text { ficha de avaliação; } \\
\text { * Revisão das tirinhas; } \\
\text { * Editoração das tirinhas para a atividade } \\
\text { final. }\end{array}$ & $\begin{array}{l}\text { * Atividade } \\
\text { impressa com } \\
\text { orientações } \\
\text { para a } \\
\text { produção } \\
\text { final; } \\
\text { * Ficha de } \\
\text { avaliação da } \\
\text { tirinha. }\end{array}$ \\
\hline
\end{tabular}

Fonte: Vargas (2011, p. 130-134). Adaptado

Após percorrermos as seções destinadas a caracterizar as SD, apresentamos um exemplo comentado, bastante claro, de como esse instrumento metodológico é construído. Esperamos que as discussões aqui travadas sejam realmente úteis aos leitores, especialmente aos professores, de modo que essas reflexões sejam concretamente aproveitadas no cotidiano de nossas aulas de Língua Portuguesa. 


\section{Considerações finais}

Ao final deste capítulo, queremos concluir nossas reflexões com base em Dolz, Noverraz e Schneuwly (2004, p. 125): "Produzir textos é um processo complexo. A aprendizagem de tal conhecimento é lenta e longa". Logo, não há fórmulas mágicas ou receitas milagrosas para que todos os alunos se transformem em exímios leitores e escritores de forma instantânea. Essa expectativa seria fortemente ingênua.

Vargas e Magalhães (2011, p. 141-142) também abordam essa questão sob outro ponto de vista, centrado nas SD:

Seria ingênuo acreditar que todos os alunos resolverão as suas dificuldades de produção de textos após o desenvolvimento de uma SD. Os conhecimentos sobre o gênero, as atividades de compreensão e produção textual criam uma aproximação aos gêneros estudados, mas que será ampliada na escrita de outros textos, produzidos com outros objetivos, em diferentes momentos. Trata-se de uma longa aprendizagem. Ressalte-se, também, que a SD é um instrumento dinâmico, ou seja, sua organização permite inserções de atividades de acordo com a observação do professor a respeito do desenvolvimento das capacidades de linguagem dos alunos, seus conhecimentos prévios e suas experiências culturais. (VARGAS; MAGALHÃES, 2011, p. 141-142)

A SD é, sem dúvida, um instrumento de comprovada efetividade para um ensino profícuo de Língua Portuguesa. Esse caráter positivo das $\mathrm{SD}$ se deve, pelo menos parcialmente, a seu caráter maleável e plástico, que permite adaptações por parte do professor, a depender das necessidades da turma. Afinal, a análise da produção textual inicial e o desempenho ao longo dos módulos são importantes indicativos para refinamentos e reconsiderações de todo trabalho por parte do professor. Igualmente importante é a organização passível de outros itinerários para cada parte da SD.

Apesar de toda sua eficiência, contudo, devemos lembrar que o trabalho pedagógico do professor de Língua Portuguesa pode e deve estar ancorado em outras práticas de ensino-aprendizagem. Dolz, Noverraz e 
Schneuwly (2004, p. 114) defendem, por exemplo, que "as sequências não podem assumir a totalidade do trabalho necessário para levar os alunos a um melhor domínio da língua e devem apoiar-se em certos conhecimentos, construídos em outros momentos". Em outras palavras, apesar de sua grande eficácia, as SD não são cartilhas ou guias herméticos, a ponto de tolher o professor com relação a novas ideias e práticas.

Araújo (2013, p. 324), no contexto do Ensino Médio, com base em trabalhos desenvolvidos com o gênero artigo de opinião, defende:

Adotar esse modelo na nossa realidade requer adaptações. $\mathrm{O}$ trabalho de Freitas (2004) demonstra que quando os alunos não sabem um gênero não parece interessante solicitar a produção diagnóstica. No caso da experiência por ela coordenada, a percepção da falta de experiência dos alunos de ensino médio de uma escola pública com estratégias argumentativas escritas levou à remodelação da proposta da escola de Genebra, iniciando por um módulo que se destinava a ensinar a ler o gênero artigo de opinião, para depois ensinar reconhecer estratégias argumentativas usadas e, por fim, levar a escrever o gênero. As produções finais foram publicadas em jornal de referência da cidade. Nesse caso, vemos que o ensino de um gênero escrito começou com o ensino de como ler esse gênero no que diz respeito à sua composição textual e discursiva.

Essas observações finais não depõem contra a eficácia das SD. Ao contrário, o objetivo é demonstrar que esse recurso metodológico compatibiliza-se com outros instrumentos que possam ser acessados pelo professor. Ademais, a própria SD precisa ser vista como um modelo aberto, sujeito a adaptações.

Afinal, as práticas rarefeitas de letramento dos nossos alunos podem fazer, por exemplo, que eles se sintam desmotivados ou até incapacitados de elaborar a produção inicial. Assim, uma das propostas alternativas possíveis é iniciar a SD com um trabalho intenso e consistente de reconhecimento dos gêneros, especialmente por meio de leitura. Essa adaptação é possível e até imperiosa, a depender da realidade da turma. 
Enfim, a SD é, sem dúvida, um poderoso instrumento à disposição do professor, com resultados positivos já comprovados. Sua organicidade permite orientar o aluno por meio de um percurso seguro e teoricamente consistente, fora de espontaneísmos e subjetivismos. É fundamental que os professores de Língua Portuguesa possam se apropriar cada vez mais desse modelo, de modo a inseri-lo em sua prática docente, de forma adaptada ou não.

\section{Exercícios}

1. Que atividades extras podem enriquecer as sequências didáticas?

2. Se você fosse trabalhar o gênero noticia jornalistica em uma turma de Ensino Médio, como você conduziria a etapa de apresentação da situação?

3. Que aspectos o professor deve observar na produção textual final dos alunos em comparação com a produção inicial?

4. De que forma é possível compatibilizar um bom trabalho didático entre análise linguística e ortografia no contexto das SD?

5. Por que a modularidade é um conceito importante no campo das SD?

6. Com base na proposta de Vargas e Magalhães (2011), crie um módulo cujo objetivo seja trabalhar a questão do modo imperativo no gênero textual receita culinária. Esse módulo deverá ser aplicado a uma turma hipotética do sexto ano do ensino fundamental. Apresente objetivos, atividades e materiais.

\section{Resumo}

Este capítulo teve como objetivo apresentar as sequências didáticas (SD) como instrumento metodológico útil para o trabalho dos professores em Língua Portuguesa, na Educação Básica. Dolz, Noverraz e Schneuwly (2004, p. 97) definem as SD como "um conjunto de atividades escolares organizadas, de maneira sistemática, em torno de um gênero textual oral ou escrito". A SD é formada por quatro partes principais: a) apresentação da situação; b) produção inicial; c) módulos; d) produção final. 
Desde o início, defendemos que todo trabalho com língua materna deve basear-se no texto, que encontra grande centralidade na proposta apresentada. De fato, toda SD parte do texto e volta ao texto. Essa perspectiva, de base funcional e sociointerativista, permite um foco maior nos processos de leitura, interpretação e compreensão. Apesar disso, sem dúvida, os estudos gramaticais, ortográficos e outras fontes de conhecimentos podem e até devem se integrar ou compatibilizar com as SD.

As SD devem sempre ser concebidas em uma perspectiva baseada na progressão, em que os gêneros textuais são apresentados aos alunos em níveis graduais de complexidade. Essa perspectiva deve objetivar que os alunos sejam capazes de capitalizar aquisições, ou seja, que eles adquiram linguagem técnica necessária para falar sobre os gêneros.

É importante também situar as SD nos seus contextos de produção. Dolz, Noverraz e Schneuwly (2004, p. 126) propõem que os gêneros textuais sejam alocados em cinco "agrupamentos": narrar, relatar, argumentar, transmitir informações e regular comportamentos. Esses agrupamentos mobilizam o estudo das sequências tipológicas ou discursivas, que constituem os gêneros textuais em si.

Todo trabalho didático com as SD deve partir de um bom planejamento do professor, com aspectos claros no que tange à avaliação. Além disso, a modularidade (processos de observação e descoberta) deve sempre governar a formulação das SD. Nem sempre será possível aferir total aproveitamento das atividades propostas. Afinal, ler e produzir textos são práticas altamente desafiadoras. Por fim, deve-se destacar que toda SD deve ser flexível, a depender das necessidades e interesses dos alunos, dos resultados das avaliações realizadas pelo professor e de outros fatores. 


\section{Referências}

ARAÚJO, Denise Lino. O que é (e como faz) sequência didática? In: Entrepalavras. Fortaleza, v. 3, n. 1, p. 322-334, jan./jul. 2013. Disponível em: http://www.entrepalavras.ufc.br/ revista/index.php/Revista/article/view/148. Acesso em: 2 out.2018.

BRASIL. Secretaria de Ensino Fundamental. Parâmetros Curriculares Nacionais de Língua Portuguesa. 30 e 4º ciclos. Brasília: MEC, 1998.

DOLZ, Joaquim; NOVERRAZ, Michele; SCHNEUWLY, Bernard. Sequências didáticas para o oral e a escrita: apresentação de um procedimento. In: DOLZ, Joaquim; SCHNEUWLY, Bernard e colaboradores. Gêneros orais e escritos na escola. Trad. e Org. de Roxane Rojo e Glaís Sales Cordeiro. Campinas, SP: Mercado das Letras, 2004.

MARCUSCHI, Luiz Antônio. Oralidade e ensino de língua: uma questão pouco 'falada'. In: DIONÍSIO, Angela Paiva; BEZERRA, Maria Auxiliadora (Org.). O livro didático de Português. Rio de Janeiro: Lucerna, 2003.

ROSÁRIO, Ivo da Costa. Texto e gramática no mundo da leitura: fronteiras e sobreposições. In: DIAS, André; FERES, Beatriz dos Santos; (Org.). Leitura e formação do leitor: cinco estudos e um relato de experiência. Rio de Janeiro: 7Letras x FAPERJ, 2016.

VARGAS, Suzana Lima; MAGALHÃES, Luciane Manera. O gênero tirinhas: uma proposta de sequência didática. In: Educação em Foco. Rio de Janeiro, v. 16, n. 1, p. 119-143, mar./ago. 2011. Disponível em: http://www.uff.br/revistaedufoco/files/2012/08/Texto-05. pdf. Acesso em: 2 out.2018. 



\section{TEXTO EM QUESTÃO: CONCEITOS E APLICAÇÕES}

Patrícia Ferreira Neves Ribeiro (UFF)

\section{Objetivos}

Ao final deste capítulo, você deverá ser capaz de compreender

- que a linguagem humana cumpre duas funções básicas: a simbólica e a comunicativa;

- quais as relações entre linguagem e língua;

- por que a distintas concepções de língua correspondem diferentes definições de texto;

- por que o contexto tem importância definitiva na construção do sentido em atividades de leitura e produção de texto.

- quais as relações entre texto e discurso e suas implicações para o ensino de língua.

... o texto é um construto histórico e social, extremamente complexo e multifacetado, cujos segredos (quase ia dizendo mistérios) é preciso desvendar para compreender melhor esse "milagre" que se repete a cada nova interlocução - a interação pela linguagem, linguagem que, como dizia Carlos Franchi, é atividade constitutiva....

(KOCH, 2003, p. 9)

\section{O texto em questão}

Parece já bastante consensual, tanto em Linguística Teórica quanto em Linguística Aplicada, que o texto assume lugar central nas salas de aula de ensino de Língua Portuguesa. Esse consenso ecoa nas diretrizes mais amplas propostas pelos Parâmetros Curriculares Nacionais, desde a década de 90, conforme o que se afirma: 
Se o objetivo é que o aluno aprenda a produzir e a interpretar textos, não é possível tomar como unidade básica de ensino nem a letra, nem a sílaba, nem a palavra, nem a frase que, descontextualizadas, pouco têm a ver com a competência discursiva, que é questão central. Dentro desse marco, a unidade básica de ensino só pode ser o texto, mas isso não significa que não se enfoquem palavras ou frases nas situações didáticas específicas que o exijam (BRASIL, 1998, p. 29).

Além disso, essa prática de ensino de língua centrada no texto atualiza-se na operacionalização sistêmica do que ensinar, progressivamente, segundo o que orienta a recém homologada Base Nacional Comum Curricular (BRASIL, 2018). Definem-se, com base na BNCC, competências específicas e habilidades a serem exercitadas e constituídas no âmbito de um ensino que vise à ampliação e à consolidação de práticas de linguagem centradas sobre textos orais e escritos em suas múltiplas semioses.

Assim, alguma objeção que se possa fazer acerca do ensino de língua não passa pela eleição do objeto central para esse fim, já que a aceitação de que o texto deve ser a unidade básica de ensino de língua parece ser mesmo definitiva. $\mathrm{O}$ que merece ainda ser problematizada é a concepção de texto sobre a qual tem se assentado, na prática, a condução do trabalho com a linguagem na educação básica. A esse respeito, o linguista Luiz Antônio Marcuschi assim posiciona-se:

Sabemos que um problema do ensino é o tratamento inadequado, para não dizer desastroso, que o texto vem recebendo, não obstante as muitas alternativas e experimentações que estão sendo hoje tentadas. Com efeito, introduziu-se o texto como motivação para o ensino sem mudar as formas de acesso, as categorias de trabalho e propostas analíticas (MARCUSCHI, 2008, p. 52).

Se, muitas vezes, as mencionadas "formas de acesso", "categorias de trabalho" e "propostas analíticas" relativas a textos em sala de aula têm servido apenas para considerá-los como pretexto ao estudo de aspectos estruturais da língua descontextualizada, parece, então, ainda haver certa 
carência - por parte de alguns docentes - quanto aos saberes a serem elucidados na direção de fazer do texto o verdadeiro objeto de ensino de língua materna.

Diante desse quadro, a complexidade da questão requer que se reflita ainda sobre a necessidade já enfatizada na obra clássica $O$ texto na sala de aula, organizada por João Wanderley Geraldi (1999), acerca de se adotar, no cotidiano das aulas de Língua Portuguesa, uma concepção de linguagem, não apenas como um código transparente, mas como lugar de interação. Isso confere possibilidade de atualização de metodologias tradicionais de ensino de texto com base nas contribuições de teorias enunciativo-discursivas.

Nesse sentido, a linguagem, definida segundo um caráter dialógico, como nos ensina o pensador russo Mikhail Bakhtin, permite a expansão do conceito de texto, tomando-o como atividade intersubjetiva, isto é, palavra que "serve de expressão a um em relação ao outro" (BAKHTIN,1981, p.113). Soma-se a isso a ampliação do conceito de texto em perspectiva discursiva, considerado como atividade dinâmica situada, com base em um "contrato comunicativo" - pilar de dado gênero discursivo - a manifestar elementos linguísticos e extralinguísticos.

Todos esses aspectos concernentes à questão do texto conduzirão a confecção deste capítulo que pretende, de forma teórica e aplicada, não só tecer reflexões sobre distintos conceitos de texto - em cuja base estão distintas funções e concepções de linguagem e de língua - como também contribuir com outros estudos que o têm colocado também em questão.

Relativamente à organização deste capítulo, dispõe-se da seguinte divisão. Além desta introdução, de exercícios e de um resumo propostos ao final, há mais cinco partes a integrarem-no: na primeira, fazemos apontamentos sobre a linguagem e sua dupla função; na segunda, realizamos uma exposição a respeito das relações entre linguagem e língua; na terceira, apresentamos convergências entre concepções de língua e de texto; na quarta, discorremos sobre processamento textual e contextos; na quinta, por fim, tecemos considerações sobre texto em dimensão discursiva. 


\section{A linguagem e sua dupla função}

Da história à biologia, da filosofia à psicologia, todos os campos de estudo que elegem o homem como objeto de apreciação e de análise debruçam-se, inegavelmente, sobre aquilo que o singulariza: sua linguagem. $\mathrm{Na}$ posse da linguagem, delineia-se uma fronteira entre o universo humano e o mundo dos animais irracionais (AZEREDO, 2000, p.15).

É possível que, neste momento, surja a pergunta sobre a propalada "linguagem dos animais"; afinal, cães, lobos e gatos emitem latidos, uivos e miados, isto é, dispõem de sinais fônicos para a expressão de seus sentimentos. Muito embora os animais irracionais sejam dotados de um sistema para a produção de alguma mensagem, tal sistema encontra equivalência tão-somente no conceito de código de sinais. Isso significa dizer que, sendo um código de sinais, a linguagem dos animais irracionais caracteriza-se, distintamente da linguagem humana, pela fixidez do conteúdo, pela invariabilidade da mensagem, pela vinculação a uma situação específica, pela relação unilateral estabelecida entre emissor e receptor e pela impossibilidade de decomposição dos enunciados produzidos. É conhecida a emissão de diferentes rugidos pelos leões, seja para identificar algum membro da alcateia, seja para afugentar possíveis invasores. Não se tem notícia, contudo, de que, por exemplo, estabeleça-se, a partir daí, algum diálogo, entre os membros da espécie, no lugar da mera apresentação de uma conduta como resposta.

Em sentido oposto, a linguagem humana particulariza-se, sobretudo, por sua propriedade fundamental de articulação, a possibilitar, com um número limitado de elementos, a formulação de múltiplas mensagens a serem transmitidas e retransmitidas em situações dialógicas. Em outubro de 2018, por exemplo, uma famosa rede de lanchonetes americana, instalada há décadas no Brasil, anuncia seus já clássicos produtos, associando-os aos dias da semana. No anúncio, podemos observar um sanduíche diferente para cada dia da semana, em que se utilizam as expressões: quintou, sextou, domingou e segundou ${ }^{1}$.

\footnotetext{
${ }^{1} \mathrm{O}$ anúncio está disponível no site a seguir: https://geekpublicitario.com.br/15605/classicodo-dia-mcdonalds/ - Acesso em 02/10/2018.
} 
Nessa publicidade, observamos as espirituosas combinações entre os radicais nominais doming-, segund-, quint- e sext- e a típica desinência verbal de terceira pessoa do pretérito perfeito do indicativo: -ou. Por meio dessas novas e criativas combinações, é gerada uma gama de possibilidades de significação, traço característico da linguagem humana. Do mesmo modo, da escrita literária de José Paulo Paes (2005, p.13), atestamos também o caráter criativo da linguagem autorizado pelo bem-humorado trocadilho: "Quem é o barão do mar / Só tubarão". O substantivo "tubarão" é atravessado pela singela combinação entre o pronome pessoal do caso reto "tu" e o substantivo "barão", por obra da lúdica (re)composição proposta pelo poeta.

No que tange ainda à linguagem humana, fixando-se, mais uma vez, na seara da literatura, a obra-prima de Graciliano Ramos - Vidas Secas - nos ajuda a perceber a desumanização da personagem central do romance, o retirante Fabiano. O perfil animalizado de Fabiano encontra eco justamente em sua incapacidade declarada de lidar com a característica fundamental da linguagem humana de ser um substituto da experiência, passível de transmissão infinita no tempo e no espaço. Fabiano é assim descrito pelo narrador do romance: "Na verdade falava pouco. Admirava as palavras compridas e difíceis da gente da cidade, tentava reproduzir alguma, em vão, mas sabia que eram inúteis e talvez perigosas”. (RAMOS, 1989, p.20).

Romance escrito em terceira pessoa, a pôr em evidência, predominantemente, os pensamentos de Fabiano por recurso ao discurso indireto livre, Vidas Secas declara o primado da linguagem na constituição da natureza humana. Disso resulta a grandiosa conclusão: estudar a linguagem e suas diversas formas de composição é, pois, estudar o próprio ser humano.

Quando nos perguntamos sobre a função primordial da linguagem na vida humana, a resposta imediata que nos vem à mente vincula-se à função comunicativa. É inegável que, sendo um ser social, o homem precise comunicar-se com o outro e o faça por alguma forma de linguagem, independentemente do suporte que acesse ou dos instrumentos de que se utilize. Das tábuas de argila, passando pela madeira, pelo papel e chegando à tela do computador ou à do celular, emerge, inegavelmente, aquela que 
parece ser a função incontestável da linguagem: a de possibilitar a comunicação entre os homens em sociedade.

Embora essa função social da linguagem seja bastante clara, não é a única. Antes, há outra que figura na base da primeira. Trata-se da função simbólica da linguagem.

Todos nós, seres humanos, somos gestados no útero materno, sendo esse nosso primeiro espaço de acolhimento. Quando nascemos, entretanto, somos inseridos em um outro mundo: o universo da linguagem. Por esse filtro - denominado linguagem - aprendemos a nos informar sobre o que está ao nosso redor. E isso é possível, uma vez que, dotada de função simbólica, a linguagem estabelece uma ligação entre o sujeito e o mundo a significar. Em outros termos, assumindo como função representar a realidade, a linguagem permite estruturar a experiência humana perante o mundo em dados de conhecimento significativos.

Em A Lingua Mãe (BARROS, 2001, p.24-25), o poeta mato-grossense Manoel de Barros, conferindo atenção especial à relação entre as palavras e as coisas, nos instiga a pensar sobre o papel simbólico da linguagem:

Não sinto o mesmo gosto nas palavras:

oiseau e pássaro.

Embora elas tenham o mesmo sentido.

Será pelo gosto que vem de mãe? De língua mãe?

Seria porque eu não tenha amor pela lingua

de Flaubert?

Mas eu tenho.

(Faço este registro

porque tenho a estupefação

de não sentir com a mesma riqueza as

palavras oiseau e pássaro)

Penso que seja porque a palavra pássaro em

mim repercute a infância.

E oiseau não repercute. 


\section{Penso que a palavra pássaro carrega até hoje}

nela o menino que ia de tarde pra

debaixo das árvores a ouvir os pássaros.

Nas folhas daquelas árvores não tinha oiseaux

Só tinha pássaros.

É o que me ocorre sobre lingua mãe.

Ao identificar que a realidade configura-se, perceptivelmente, de formas diferentes segundo a enunciação do objeto "pássaro" em duas línguas distintas, o francês e o português - seu idioma materno, Manoel de Barros mostra-se sensível ao poder simbólico da linguagem. Embora reconheça que, referencialmente, as palavras "pássaro" e "oiseau" compartilhem o mesmo significado, sente, em termos de simbolização, gostos diferentes ao enunciá-las. Entre o homem Manoel de Barros e o mundo, está a palavra "pássaro", a ultrapassar seu mero papel nomeador e a criar um universo simbólico particular, timbrando sensações sobre a natureza que o envolve, ligadas à memória de um tempo passado, a infância. Assim, é possível afirmar que, embora as palavras “oiseau" e "pássaro" possam dar nome ao mesmo objeto da realidade, constituem dois modos distintos de representá-lo, uma vez que a simbolização do mundo pela linguagem depende das experiências humanas e do conhecimento. Essa ideia ecoa a afirmação do pesquisador Mario Perini de que "cada palavra não apenas exprime uma coisa; ela também define esta coisa, à sua maneira particular" (PERINI, 2001, p.102).

É notório que, muitas vezes, nos conformamos diante de valores simbólicos que se acenam como que oferendas da natureza no mercado de etiquetas linguísticas. Por exemplo, apesar de sabermos, há muito tempo, que é a Terra que gira em torno do Sol, não nos cansamos de dizer, todos os dias, que "o sol se põe”. Entretanto, tantas outras vezes - inconformados - nos questionamos sobre a maneira como as palavras recortam e organizam a realidade, sabendo que, segundo a função simbólica, cada palavra não somente expressa um significado, como também determina um ponto de vista bastante particular, uma visão própria de mundo. $\mathrm{Na}$ atualidade do mundo empresarial, por exemplo, a mudança quanto ao emprego do termo que designa o trabalhador 
- de "empregado" para "colaborador" - não passa em branco aos olhos inconformados daqueles que veem, na troca, a instauração proposital de uma nova ordem de compreensão da realidade, a amenizar o sentido do primeiro termo.

Diante do que foi tratado até aqui, podemos considerar que a linguagem, mediadora da relação entre homem e mundo, assume, portanto, uma dupla função essencial: a função social ou comunicativa e a função simbólica ou representativa.

\section{Linguagem e língua}

A linguagem possibilita um vasto intercâmbio entre o homem e o mundo. Essa troca realiza-se com o apoio de variados códigos semiológicos, isto é, de representações simbólicas da realidade por multifacetados signos. Por exemplo, o anúncio de que se deseja decretar o fim de um acontecimento pode ser dado tanto pela bandeira branca em contexto de guerra, quanto pelo apito de um juiz nos campos de futebol e, até mesmo, pela troca da posição de uma bolsa, protagonizada pelas rainhas no jogo cerimonioso das situações formais.

Há que se ressaltar, contudo, que, podendo ser também um sujeito de "fala", o homem poderá fazer uso de uma linguagem especial, correspondente a um sistema organizado em torno de sons (ressalvando-se as línguas dos sinais), palavras e frases. Trata-se, pois, da linguagem verbal reconhecida nas diversas linguas naturais: português, francês, inglês etc. Tomada como uma instituição social e uma criação histórica e coletiva, toda língua é definida como um sistema de signos verbais, existente em virtude do uso que os falantes fazem dela para expressar ideias, desejos, anseios, impressões e sentimentos.

Ao longo da História, as visões sobre língua têm sido atravessadas por, pelo menos, três feições diversas a que correspondem três distintas concepções de texto e diferentes abordagens pedagógicas no cotidiano das salas de aula da educação básica. A esse propósito, Koch e Elias (2009, p.32) afirmam que "subjaz uma concepção de linguagem, de texto e de sujeito 
escritor ao modo pelo qual entendemos, praticamos e ensinamos a escrita, ainda que não tenhamos consciência disso".

$\mathrm{Na}$ próxima seção, passaremos a apreciar essas distintas concepções de lingua e as de texto que lhes são correspondentes.

\section{Língua e texto}

Por largo tempo, considerou-se texto como unidade associada apenas à escrita, sobretudo filiada aos domínios pedagógico e literário. Sob essa consideração, textos eram analisados, por exemplo, conforme a exclusiva apreciação feita, a seguir, do enunciado ilustrativo: "Ana tem trinta anos".

Diante desse texto, ao leitor cabia apenas o papel de aderir ao conteúdo referencial previsto por um sujeito, correspondente, respectivamente, aos sintagmas "Ana" e "tem trinta anos": "nome atribuído a uma mulher" e "idade alcançada no tempo presente".

Sob essa leitura, advêm duas concepções de língua que podem ser sintetizadas como: representação ("espelho") do pensamento e instrumento (“ferramenta”) de comunicação.

Como espelho do pensamento, a lingua é vista como aquilo que reflete o conhecimento de um sujeito absoluto, sua representação mental, que - em nada - é afetada pelo outro nem pela situação social em que se circunscreve. Nesse caso, não importam a identidade do sujeito e a finalidade do dizer para a construção do sentido. Sob essa perspectiva, o texto é assumido como um artefato lógico do pensamento do produtor, devendo o leitor apenas captar a intenção posta, ou seja, o que "o autor quis dizer".

Nessa concepção de texto, não há espaço para uma reflexão, por exemplo, acerca do fenômeno linguístico-discursivo da ambiguidade involuntária, já que o que está escrito deve corresponder exatamente ao que foi delineado pelo autor do texto. Diante, por exemplo, do enunciado proferido pela ex-mulher do homem que interpretou o personagem Bozo por longos anos ("Ele (Bozo) era um palhaço"), embora flagremos dois sentidos possíveis (o da descrição correspondente tanto à profissão quanto ao insulto), nessa visão de texto, apenas um sentido imperará, justamente aquele correspondente à representação mental do produtor do texto. 
Por sua vez, como ferramenta de comunicação, a lingua é tomada como um código, isto é, como um sistema de signos que se combinam segundo regras a possibilitar a transmissão de informações entre polos neutros de comunicação: o emissor e o receptor. Sob esse enquadramento, o texto é considerado resultado da codificação de um autor a ser decodificado pelo ouvinte/leitor, sendo suficiente o domínio do código linguístico empregado para o entendimento da mensagem.

Nessa visão de texto, não há caminhos para uma análise dos implícitos, uma vez que a linearidade do dizer e a transparência quanto ao uso do código ditam a construção do sentido. Diante, mais uma vez, do enunciado "Ele (Bozo) era um palhaço", apesar de ser inegável a projeção de um segundo efeito de sentido - conforme o que se explora, a propósito, na capa do jornal Meia Hora de Notícias, em que se lê "Ex-mulher detona Bozo: 'ele era um palhaço", - esse será relegado em nome da máxima de que "tudo está dito no dito". (KOCH; ELIAS, 2009, p.33)².

Essas duas concepções básicas de texto, como artefato lógico do pensamento e como (de)codificação de ideias, fundamentam a perspectiva de texto como continente e como produto. Compreender um texto, sob essas concepções, é apreender objetivamente os conteúdos por ele transportados. A ação objetiva de compreender centra-se sobre o código e sobre a função informacional, uma vez que, dentro desse paradigma, a língua tem autonomia plena relativamente aos sujeitos e à situação comunicativa.

Assim é que, retomando o exemplo dado inicialmente, "Ana tem trinta anos", só será possível lê-lo segundo a linearidade do texto e a transparência do código. Em atividades de leitura realizadas em sala de aula, partindo da literalidade do sentido e chegando a uma metalinguagem classificatória, que identifica classes e funções dos termos dados, ao professor restará formular questões como: "O que o autor quis dizer"; "Aponte a classe de palavra do termo Ana"; "Qual o significado da palavra trinta"; "Classifique sintaticamente "anos", dentre outras de mesma natureza.

\footnotetext{
${ }^{2}$ Imagem da capa do Meia Hora disponível em: https://www.naosalvo.com.br/as-25-melhores-capas-do-jornal-meia-hora/- Acesso em: 20 out.2018.
} 
Aliás, essa visão de texto como produto, pretexto a ser utilizado em atividades unicamente voltadas para uma metalinguagem classificatória, tem estimulado alunos a verem-no, exclusivamente, sob essa perspectiva. Isso pode ser comprovado pela resposta a uma questão de Língua Portuguesa dada por um dos candidatos ao vestibular CEDERJ-2013/2. Seguem a questão e a resposta, relativamente ao poema $\grave{A}$ moda da casa, de José Paulo Paes:

$O$ titulo do poema remete a determinado tema. Identifique esse tema e explique como ele se relaciona com o texto do poema:

$\grave{A}$ moda da casa

Feijoada

Marmelada

Goleada

Quartelada

Resposta: O título do poema "À moda da casa" tem relação com o (modo) subjuntivo.

Retomado o exemplo "Ana tem trinta anos", vislumbramos, contudo, a existência de uma nova concepção de língua e de texto. Na atualidade, a ideia de ação norteia tanto a concepção de língua como forma ("lugar") de interação quanto a noção de texto subjacente, correspondente à de evento interativo entre sujeitos interlocutores.

Como forma de ação, a língua é assumida como uma atividade interativa orientada em nome de uma finalidade, contratualmente acertada entre interlocutores, em dada situação comunicativa. Sob esse ponto de vista, o texto é considerado como um "evento comunicativo em que convergem ações linguísticas, culturais, sociais e cognitivas” (BEAUGRANDE, 1997, p.10). Trata-se, pois, de um ato de linguagem encenado entre sujeitos em interação e dependente de uma situação comunicativa. Essa situação de comunicação acaba por determinar, com base em uma finalidade específica, o atravessamento sobre os textos de um universo de referências de saberes de crença e de conhecimento, de identidades sociais dos interlocutores e de formas linguísticas correspondentes. 
Com base nesse entendimento, o conceito de texto é assimilado à ideia de produção, já que o sentido não é dado previamente, mas estabelece-se na relação dinâmica entre locutor-co(n)texto-interlocutor (CAVALCANTE, 2013, p.20). Em atividades de leitura, por exemplo, para compreender um texto, o leitor deve ter uma ação participativa decisiva, preenchendo lacunas, realizando associações intertextuais, estabelecendo correlações. Em outros termos, assume-se, na lida com o texto, o paradigma da inferência, da formulação de hipóteses ditada por uma postura que se pauta numa "compreensão responsiva ativa", de que nos fala Bakhtin (1992).

No exemplo já exposto "Ana tem trinta anos", flagram-se novas possibilidades de leitura, fundadas sobre uma espécie de "espiralidade" textual e opacidade do código. Cabem agora, perante o texto dado, formulações que conduzem os leitores a indagar sobre "como o texto diz", "por que o texto diz assim", "para que o texto diz", "em relação a que o texto diz", reconhecendo-o como um claro espaço de correlações. Inclusive, recriando-se pelo menos duas cenas enunciativas, autoriza-se a produção de dois efeitos de sentido diametralmente opostos para o texto "Ana tem trinta anos". Por um lado, em uma situação profissional, a informação curricular confere a Ana o status positivo de profissional experiente que merece ser contratada; por outro lado, em uma situação pessoal de gravidez, a informação exposta, por exemplo, no prontuário médico de Ana, pode ser indicativa de necessidade de maiores cuidados com a saúde da paciente.

A construção do sentido é, sob essa perspectiva, não apenas dependente das formas linguísticas e seus modos de combinação, presentes na superfície textual, mas também dos contextos sociocomunicativo, histórico e cultural que os engendram. Consideremos, para exemplo, um anúncio publicitário do Mc’Donalds, em que se lê o seguinte: "Em 21 e 22/09, diga eu não bebo \#milkfake. Ganhe um milk-shake na compra de um trio". ${ }^{3}$

Debruçando-se sobre a frase "Eu não bebo \#MILKFAKE", é perceptível que a leitura linear e transparente das formas linguísticas

\footnotetext{
${ }^{3}$ Publicidade disponível no site: https://www.mundodomarketing.com.br/ultimas-noticias/.html - Acesso em: 5 out.2018.
} 
combinadas em dimensão sintagmática não é suficiente para promover o entendimento pleno do anúncio produzido e do jogo de vozes ali instaurado para capturar o consumidor. Com vistas ao pleno entendimento do texto apresentado, é essencial garantir o reconhecimento dos seguintes elementos da teia comunicativa: detectar que a bebida da imagem corresponde ao milk shake sabor crocante e acenar para o fato de que só na lanchonete idealizadora da referida bebida (Bob's) encontra-se o original sabor. De posse desses saberes, são ativadas outras informações de ordem social e cultural, segundo as quais, por exemplo, identificamos o item lexical "\#MILKFAKE" ao referente "milk shake de ovomaltine", agora vendido pelo concorrente (Mac Donald's), após perda de exclusividade da marca pelo Bob's. Para garantir a fidelização dos clientes, o Bob’s aposta que os consumidores continuem devotos do legítimo milk shake crocante lá produzido, a despeito de o ingrediente original ter passado a ser de uso exclusivo do Mc Donald's, o que, segundo a publicidade, não garante a "verdade" do sabor original.

O exemplo apresentado em dimensão verbo-visual nos conduz também a reparar que o conceito de texto, hoje, alarga-se em direção ao que se pode realizar segundo múltiplas semioses. Sua realização pode ser verbal (como o poema de Manoel de Barros supramencionado), visual (como um quadro) e verbal e visual (como as publicidades apresentadas), e sua circulação pode se dar em ambientes analógicos e digitais, o que amplia ainda mais as questões postas sobre texto.

Do que foi exposto, podemos agora com mais conviç̧ão nos filiar à segunda resposta dada por Koch, apresentada na citação transcrita a seguir, diante da pergunta fundamental: "E o texto tem segredos?".

Bem, se você achar que o texto é um artefato linguístico formado pela combinação de letras (ou sons) que formam palavras que rotulam coisas ou estados de coisas do mundo real que formam sentenças que têm um sentido literal, que existem textos totalmente explícitos descontextualizados e autônomos que para produzir e compreender textos basta dominar o código etc... etc... é claro que a resposta só poderá ser negativa. 
MAS... se você pensar o texto como lugar de constituição e de interação de sujeitos sociais, como um evento, portanto, em que convergem ações linguísticas, cognitivas e sociais (Beaugrande, 1997), ações por meio das quais se constroem interativamente os objetosde-discurso e as múltiplas propostas de sentidos, como função de escolhas operadas pelos co-enunciadores entre as inumeráveis possibilidades de organização textual que cada língua thes oferece... Então você compreenderá que o texto é um construto histórico e social, extremamente complexo e multifacetado, cujos segredos (quase ia dizendo mistérios) é preciso desvendar para compreender melhor esse "milagre" que se repete a cada nova interlocução - a interação pela linguagem, linguagem que, como dizia Carlos Franchi, é atividade constitutiva... (KOCH, 2003, p.9).

Parece claro então que, para desvendar/produzir os segredos textuais, o leitor/produtor precisa acessar/produzir estratégicas pistas linguísticas que têm de estar entrelaçadas para a garantia de uma unidade de sentido e por intermédio das quais são ativados vários tipos de conhecimento - sendo eles de natureza não só linguística, mas também enciclopédica e interacional. Na seção a seguir, discorreremos sobre esses variados conhecimentos constitutivos dos textos.

\section{Texto e contexto}

$\mathrm{Na}$ atividade constitutiva de leitura e produção de textos, um repertório de conhecimentos armazenado na memória dos sujeitos tem de ser necessariamente ativado. Segundo Cavalcante (2013, p.19), "no decorrer do processamento textual, vários tipos de conhecimentos armazenados em nossa memória são ativados para nos auxiliar na compreensão e na produção de sentido".

Em termos práticos, consideramos basicamente três tipos de conhecimento, conforme sugestão de Koch e Elias (2009): linguístico, enciclopédico e interacional. Muito embora, didaticamente, esses três tipos de conhecimento sejam apresentados de forma separada, é válido ressalvar 
que, nas atividades de construção de sentido, todos devem ser simultaneamente ativados.

Ao conhecimento linguistico correspondem as informações acerca da gramática e do léxico de uma língua. De posse desse conhecimento, os sujeitos transitam pelos textos acessando seu complexo sistema linguístico, organizado nos níveis fonético-fonológico, morfossintático e semântico correspondentes, sem falar do eixo lexical. Para ilustração, observemos o título de uma já consagrada obra da Literatura Infantil, de autoria de Chico Buarque (2017): Chapeuzinho Amarelo.

Pela mobilização estrita do conhecimento linguístico, reconhecemos, por apelo ao nível morfossintático, uma construção formada por um substantivo, "Chapeuzinho", e por uma adjetivo, "Amarelo", sendo este termo modificador do primeiro. Em termos lexicais, é possível considerar um primeiro sentido para o termo "Chapeuzinho", correspondente ao significado de dicionário, qual seja, o de acessório usado para cobrir a cabeça. Somam-se a esse sentido o de tamanho diminuto ofertado pelo elemento mórfico "zinho" e o de coloração em tom de ouro mobilizada por "Amarelo". A mobilização desse conhecimento pode, entretanto, deixar entrever outro sentido produzido. Trata-se agora de um sentido dado pelo valor social da construção, pautado em uma classificação ajustada ao sintagma nominal "Chapeuzinho Amarelo", designador de nome próprio que tanto confere título à obra, quanto a uma personagem literária pressuposta. Sobretudo, autoriza-nos essa segunda compreensão outro tipo de conhecimento, o enciclopédico.

O conhecimento enciclopédico (ou de mundo) diz respeito ao repertório armazenado na memória dos sujeitos com base em suas experiências pessoais adquiridas, tanto formal quanto informalmente, em determinado tempo e espaço, como membros de uma comunidade discursiva. Sem ativar o conhecimento de mundo, a produção de sentido projetada para "Chapeuzinho Amarelo" como nome atribuído a uma personagem pode não ser imediatamente permitida.

Essa permissão estará garantida, entretanto, se os interlocutores compartilharem de um mesmo conhecimento cultural sobre um famoso 
conto da literatura universal, "Chapeuzinho Vermelho", cujo título faz referência, justamente, à protagonista da história. Sem acessar esse conhecimento de mundo, que nos fará dialogar com outro texto, a compreensão ficará certamente comprometida.

A propósito, esse diálogo entre um texto lido/escrito e outro, ora explicitamente citado, ora apenas aludido, atravessa qualquer produção de sentido. Textos científicos fazem remissão a obras que garantam fidedignidade às explicações apresentadas; notícias jornalísticas reportam falas dos entrevistados na busca pela credibilidade da informação; conversas espontâneas são tecidas por alusões a outras histórias. Em outros termos, na base de qualquer texto há sempre outro referenciado, citado, aludido, uma vez que nenhum texto pode ser tomado de forma isolada. Essa intrínseca relação de um texto com outros exemplares textuais é o que se tem denominado por intertextualidade (CAVALCANTE, 2013, p.145).

Por fim, temos de considerar que, na produção de sentido dos textos, entra em cena também outro tipo de conhecimento, o interacional. $\mathrm{O}$ conhecimento interacional relaciona-se ao saber que possuímos sobre as maneiras por meio das quais interagimos nas diferentes situações de comunicação. Trata-se de informações acerca de permissões e impedimentos concernentes aos comportamentos assumidos nas trocas verbais. Sabemos ser permitido dizer, com abundância de adjetivos, em uma resenha crítica, o que não é autorizado, entretanto, em uma notícia jornalística.

Em outros termos, o conhecimento do tipo interacional deixa claro que todo texto filia-se a um gênero discursivo e que, assim filiando-se, oferece tanto ao produtor quanto ao leitor uma grade de produção e de leitura relativa ao conteúdo temático, à composição gráfica e ao estilo esperado na construção de determinado texto. $\mathrm{E}$ todos esses aspectos concorrem para a materialização de um propósito comunicativo determinado no âmbito de uma situação comunicativa específica.

O exemplo a seguir busca esclarecer a necessária mobilização do conhecimento interacional para a produção de sentido: 
Corrente no WhatsApp com feriados de 2017 já é mais desejada que iPhone 7

Uma corrente que tem circulado pelo WhatsApp informando todos os feriados prolongados no ano de 2017 já é desejada por mais brasileiros que o novíssimo iPhone 7. Uma lista divulgada pela Forbes Brasil colocou a corrente em primeiro lugar, seguida pelo celular da Apple e a volta da novela "Avenida Brasil" como sonhos de consumo para o próximo ano.z

Brasileiros que ainda não receberam a corrente estão protestando em diversos pontos do país e, na Avenida Paulista, mais de três mil manifestantes gritam palavras de ordem e imploram para receber o cronograma do ano que está por vir.

"A gente não quer que o crush visualize e responda, a gente quer saber quais segundas vamos enforcar com feriados!" diz um dos cartazes.

Fonte: https://www. sensacionalista.com.br/2016/11/15/corrente-no-whatsa-ppcom-feriados-de-2017-ja-e-mais-desejada-que-iphone-7/ - Acesso em: 21 out.2018.

O texto dado aparenta tratar-se de um gênero veiculado, frequentemente, em revistas e jornais, com o objetivo de informar o destinatário sobre fato atual de relevância social. Emprega, para tanto, língua obediente ao padrão culto e a uma maior objetividade, procurando conferir impressão de imparcialidade ao leitor. Sua organização textual respeita a menção contratual aos dados essenciais da matéria, a saber: o acontecimento propriamente dito, relacionado ao momento, espaço e motivo de ocorrência.

Tais aspectos elucidados na construção do texto são percebidos pela ativação do conhecimento interacional acerca do que se sabe sobre outros textos pertencentes ao mesmo gênero discursivo, no caso, supostamente, uma notícia de jornal. Tal suposição, aliás, a propósito do texto dado, pode ser colocada em xeque pela ativação precisa de nossa experiência adquirida em interação com outros textos também tomados como notícias jornalísticas.

Lendo o texto com mais cuidado, vemos que a forma consagrada da notícia jornalística em questão apresenta certa porosidade que convida o leitor à desconfiança sobre a veracidade da matéria. Seja o conhecimento sobre a impossibilidade de a conceituada Revista Forbes Brasil divulgar uma lista de natureza análoga à indicada na matéria, seja a informação sobre 
o suporte que hospeda o texto, o site do Sensacionalista - o jornal isento de verdade, fato é que esses dois dados, dentre outros, convergem, com base, uma vez mais, no conhecimento interacional - associado ao gênero discursivo - para o leitor reconsiderar a finalidade do texto em questão. Reconhecendo haver, neste caso, a intencionalidade de provocação do riso, o referido texto é alçado ao gênero peça de humor. Assim os interlocutores assumem diferentes identidades sob esse novo contrato comunicativo e mapeiam diferentes efeitos de sentido diante do texto dado.

Todos esses conhecimentos supracitados encontram correspondência nas definições de cotexto, contexto mediato e contexto imediato. De acordo com Koch e Elias (2009, p.82), o contexto engloba, em sentido amplo, o cotexto, isto é, o ambiente ou entorno verbal produzido por elementos linguísticos. Além disso, remete tanto a contexto imediato, que diz respeito aos participantes, local, tempo de interação e à finalidade da comunicação e meio de propagação, quanto a contexto mediato, relativo ao entorno sócio-histórico-cultural.

Pela ativação dos conhecimentos linguístico, enciclopédico e interacional, e dos correspondentes contextos é que percebemos o texto em perspectiva discursiva, sendo resultado de uma "operação estratégica de comunicação, produzida por um enunciador e descodificada como tal por um leitor, em três níveis: o referencial (conteúdo contextual); o situacional (entornos sociais/contexto); e o pragmático (processo sociointerativo)." (GOUVÊA, PAULIUKONIS e MONNERAT, 2017, p.49).

A seguir trataremos dessa relação entre texto e discurso.

\section{Texto e discurso}

Como elucidado na seção anterior, a articulação entre texto e discurso está pressuposta no fato de que os mecanismos gramaticais e lexicais (cotextuais) em uso nos textos são assumidos como mobilizadores de estratégias de comunicação por parte de enunciadores, em uma situação comunicativa 
específica, que inclui entorno sócio-histórico (contexto mediato) e espaço sociointerativo (contexto imediato).

Sob um viés discursivo, o texto é apreendido segundo os possíveis efeitos de sentido advindos/construídos de/por estratégias geradoras dessas possibilidades. $\mathrm{Na}$ produção de sentido, em atividades de leitura e de produção de textos, empregar e examinar estratégias significa, para o autor e para o leitor, respectivamente, utilizar e analisar percursos voltados à adesão do outro. E esses percursos são gerados com base no emprego estratégico de elementos linguísticos e extralinguísticos. Por isso, os textos oferecem-se como lugar para o estabelecimento e desvendamento de correlações entre o significado (sentido mais amplo da língua) e a significação (sentido mais específico do discurso).

Do significado à significação, estabelece-se a passagem do sentido de lingua ao sentido de discurso (CHARAUDEAU,1999). O sentido de lingua diz respeito ao valor referencial das palavras, resultante de um "processo semântico-cognitivo de ordem categorial que consiste, dentro de um movimento centrípeto de estruturação de sentido, em atribuir às palavras traços distintivos, caracterizando-as (...) em suas relações sintagmáticas e/ou paradigmáticas”(GOUVÊA, PAULIUKONIS e MONNERAT, 2017, p.51).

Por seu turno, o sentido de discurso concerne ao valor de intencionalidade das palavras, aplicado por sujeitos em situações reais de interação, advindo de um processo semântico-cognitivo, no escopo de um movimento centrífugo (para fora da materialidade textual) de ordem inferencial, que "produz deslizamento de sentido de ordem metonímica e metafórica, por meio do qual o sujeito comunicante constrói um sentido (...) indireto ou implícito.” (GOUVÊA, PAULIUKONIS e MONNERAT, 2017, p.52).

Tomando o texto "Grana derrubou o ministro", publicado no dia 30 de abril de 2003, em Veja Essa - seção de frases que a revista Veja publica semanalmente - percebemos ser possível identificar o sentido literal ou explícito das palavras, alcançado segundo a combinação coesiva da frase enunciada por Jorge Samek, à época presidente da Itaipu Binacional. No caso, com "Grana" significando, literalmente, dinheiro, propõe-se que provável ato de corrupção conduziu ministro a afastar-se do poder. No entanto, a mobiliza- 
ção exclusiva do sentido de língua não é suficiente para a representação plena do efeito de sentido produzido em torno do texto em questão. Há que se considerar o sentido indireto ou implícito, que também deve entrar em ação para que se vá constituindo a coerência textual. No exemplo enunciado, interpreta-se a frase recrutando informação adicional apresentada em letras minúsculas, colocadas abaixo da frase principal "Grana derrubou ministro", a saber: "Jorge Samek, presidente da Itaipu Binacional, depois que Carlos Alberto Grana, secretário-geral da CUT, trombou com o ministro da Fazenda, Antonio Palocci, numa pelada em que Palocci quebrou a perna”.

Diante do exposto, se em um primeiro momento, inteirando-se do contexto linguístico, o interlocutor é levado a interpretar "Grana" como dinheiro - sob o sentido de língua -, em momento posterior, acionando seu conhecimento de mundo, atribuirá ao signo "Grana" a designação do sobrenome do secretário-geral da CUT, Carlos Alberto Grana. Sob o sentido de discurso, "Grana" codifica implicitamente um saber enciclopédico acerca do sobrenome supracitado, ao mesmo tempo que marca a intencionalidade da revista Veja em provocar uma ambiguidade voluntária sobre o ocorrido com o então ministro Antonio Palocci. Assim, verifica-se a produção de um efeito de sentido colateral já esperado perante o contexto imediato de interação (Veja-co(n)texto-leitor destinatário), qual seja, o de certa "manipulação" dos fatos noticiados na direção de, explicitamente, informar sobre ato de corrupção.

Assim, finalizando, constata-se que a construção do sentido textual articula-se ao jogo estratégico acionado por protagonistas nas relações que estabelecem entre si e com a situação comunicativa e interacional em que se encontram. E esse jogo delineia-se a cada lance intencional de articulação entre o sentido de língua, dado por uma configuração verbal explícita, e o sentido de discurso, implicitamente codificado nos saberes de mundo sobre o contexto imediato de interação e sobre o contexto mediato histórico-cultural.

Enfim, em perspectiva discursiva, o texto é considerado um "evento em situação dialógica, em que se manifestam elementos linguísticos e extralinguísticos, codificados pela gramática e realizados de acordo com um 
'contrato comunicativo' vigente para os diversos gêneros textuais" (PAULIUKONIS, 2007, p. 239).

\section{Exercícios}

1. Defina as duas funções essenciais da linguagem: a função simbólica e a função comunicativa.

2. Trace um panorama das três definições de texto assumidas no curso da História, considerando diferentes concepções de língua.

3. Discorra sobre as implicações das diferentes visões de texto para o ensino de língua materna.

4. Descreva os três tipos de conhecimento constitutivos da construção de sentido dos textos.

5. Explique a relação entre o conhecimento linguístico, de mundo e interacional e os tipos de contexto.

6. Diferencie sentido de língua e sentido de discurso.

7. Explique a importância de se considerar texto em perspectiva discursiva para o desenvolvimento da competência comunicativa dos alunos.

\section{Resumo}

A temática mais ampla deste capítulo centrou-se na questão do texto, relacionada tanto à sua compreensão quanto à sua produção. Adicionalmente, debruçou-se sobre conceitos relativos a linguagem, a lingua, a contexto a a discurso, os quais convergem - de modo fundamental - para o pleno entendimento do objeto de estudo focalizado.

Como meta mais ampla deste capítulo, assumimos o propósito de apresentar a importância social da linguagem em uso em diferentes contextos de interação humana e a necessidade fundamental de considerá-la como eixo norteador do ensino de língua, em franco diálogo com as diretrizes dos Parâmetros Curriculares Nacionais (PCN) e com as competências e habilidades tratadas pela Base Nacional Comum Curricular (BNCC). 
Para tanto, expusemos distintas concepções de texto subjacentes a diferentes definições de língua. De língua como representação do pensamento e ferramenta de comunicação, constatamos uma visão de texto como continente e produto - cuja significação deriva do agenciamento do código apartado do sujeito e da situação comunicativa. De língua compreendida também como forma de ação, enveredamos por uma visão de texto como produção - cujos efeitos de sentido derivam de formas linguísticas que, estrategicamente, agenciam universo de referências de saberes de crença e de conhecimento e de identidades sociais dos interlocutores em nome de uma finalidade em dada situação comunicativa.

$\mathrm{Na}$ atividade constitutiva do texto, nesse caso tomado como produఢ̧ão, explicitamos uma gama de variados conhecimentos implicados, simultaneamente, na construção do sentido, sendo eles de natureza linguística, enciclopédica e interacional. $\mathrm{Na}$ sequência, articulamos os três tipos de conhecimento às três distintas definições para contexto, relacionadas a cotexto, contexto mediato e contexto imediato. Pela ativação dos conhecimentos linguístico, enciclopédico e interacional, e dos correspondentes co(n)textos, aportamos em uma consideração final que vislumbra ver o texto em dimensão discursiva, suscitada com base em reflexões sobre sentido de língua e sentido de discurso. Sob uma visão discursiva, o texto é assumido como uma encenação estratégica de sujeitos em interação, sob determinadas condições contratuais vigentes em um gênero, que acionam uma série de operações linguístico-discursivas para fins de produção de determinados efeitos de sentido. 


\section{Referências}

AZEREDO, José Carlos. Fundamentos de Gramática do Português. 3. ed. Rio de Janeiro: Jorge Zahar Ed., 2004.

BAKHTIN, Mikhail. (V. N. Volochínov). Marxismo e fllosofia da linguagem. Tradução de Michel Laud e Yara Frateschi Vieira. 2. ed. São Paulo: Hucitec, 1981.

BAKHTIN, Mikhail. Estética da criação verbal. São Paulo: Martins Fontes, 1992.

BARROS, Manoel de. O fazedor de amanhecer. Rio de Janeiro: Salamandra, 2001.

BEAUGRANDE, Robert. New foundations for a science of text and discourse. Norwood: Ablex, 1997.

BRASIL. Secretaria de Ensino Fundamental. Parâmetros Curriculares Nacionais de Lingua Portuguesa. 30 e $4^{\circ}$ ciclos. Brasília: MEC, 1998.

BRASIL. Secretaria de Ensino Fundamental. Base Nacional Comum Curricular. Brasília: MEC, SEB, 2018.

BUARQUE, Chico. Chapeuzinho Amarelo. 40.ed. São Paulo: José Olympio, 2017.

CAVALCANTE, Monica Magalhães. Os sentidos do texto. São Paulo: Contexto, 2013.

CHARAUDEAU, Patrick. Análise do discurso: controvérsias e perspectivas. In: MARI, Hugo; PIRES, Sueli; CRUZ, Amadeu Roselli; MACHADO, Ida Lúcia (Orgs.). Fundamentos e dimensões da análise do discurso. Belo Horizonte: Núcleo de Análise do Discurso - FALE/UFMG, 1999, p. 27-43.

KOCH, Ingedore Villaça. Desvendando os segredos do texto. São Paulo: Cortez, 2003.

KOCH, Ingedore Villaça; ELIAS, Vanda Maria. Ler e escrever: estratégias de produção textual. São Paulo: Contexto, 2009.

GERALDI, João Wanderley. (Org.). O texto na sala de aula. 3. ed. São Paulo: Ática, 1999.

GOUVÊA, Lucia Helena; PAULIUKONIS, Aparecida Lino; MONNERAT, Rosane. Texto, Cotexto e Contexto: processos de apreensão da realidade. In: MARQUESI, Sueli Cristina; ELIAS, Vanda Maria; PAULIUKONIS, Aparecida Lino. Linguística textual e ensino. São Paulo: Contexto, 2017, p. 49-68.

MARCUSCHI, Luiz Antônio. A. Produção textual, análise de gêneros e compreensão. São Paulo: Parábola Editorial, 2008. 
PAES, José Paulo. É isso ali: poemas adulto-infanto-juvenis. São Paulo: Salamandra, 2005.

PAULIUKONIS, Maria Aparecida Lino. Texto e contexto. In: VIEIRA, Silvia Rodrigues; BRANDÃO, Silvia Figueiredo. Ensino de gramática: descrição e uso. São Paulo: Contexto, 2007, p. 239-258.

PERINI, Mário. Sofrendo a gramática: ensaios sobre a linguagem. São Paulo: Ática, 2001.

RAMOS, Graciliano. Vidas Secas. São Paulo: Editora Record, 1989. 


\section{ENSINO DE LEITURA: DO ESPECTADOR AO EXPECTADOR}

Beatriz dos Santos Feres (UFF)

\section{Objetivos}

Ao final deste capítulo, você deverá ser capaz de compreender...

- por que a leitura é um processo interativo de construção do sentido textual;

- o que é um texto multimodal verbo-visual;

- quais são as estratégias de leitura baseadas nas competências semiolinguageira, discursiva e situacional, empregadas para o desenvolvimento da capacidade interpretativa.

Interpretar é criar hipóteses.

(CHARAUDEAU, 2008)

\section{Introdução}

A Pesquisa Retratos da Leitura no Brasil ${ }^{1}$ afirma que, de acordo com o Indicador de Alfabetismo Funcional (INAF), apenas um em cada quatro brasileiros domina plenamente as habilidades de leitura, escrita e matemática, mesmo com o aumento da escolaridade média de 61\% (2001) para $73 \%$ (2011). Esses dados - assim como os de tantas outras pesquisas - acerca do desenvolvimento da capacidade cognitiva do brasileiro indicam que, embora hoje mais brasileiros sejam alfabetizados, em relação à leitura, a maioria apenas decodifica o código escrito e até compreende um conjunto organizado de palavras em seu sentido mais superficial e objetivo, mas é incompetente para interpretar o sentido global de um texto; não consegue fazer inferências a partir da relação entre o texto e seu contexto de circulação.

\footnotetext{
${ }^{1}$ http://www.abdr.org.br/site/pesquisa-retratos-da-leitura-no-brasil/ Publicado em 11 de abril de 2018. Acesso em 12 de setembro de 2018.
} 
Um leitor com essa deficiência lê pouco, em quantidade e em qualidade. É mero receptor daquilo que se apresenta a ele em textos curtos e pouco informativos, sem habilidade para perceber a intenção com que um texto um pouco mais complexo é elaborado, ou os sentidos implícitos que o compõem e que precisam ser calculados para se alcançar a interpretação em plenitude. Esse é um pseudoleitor, que não consegue reagir intelectualmente àquilo que (mal) apreende por meio de textos. Essa incapacidade alastra-se para além da leitura da escrita, refletindo-se na interpretação de textos multimodais (constituídos por linguagens diferentes, visuais, plásticas, sonoras, prosódicas, gestuais etc.), grupo em que se inclui o texto oral. Esse decifrador de palavras nem percebe os implícitos, nem critica, nem aprende sozinho: é apenas um espectador de textos.

Porém, à escola básica se atribui a responsabilidade de desenvolver a capacidade de ler não só os textos escritos, mas, sobretudo, sempre alimentado por essa leitura, o mundo. É preciso, então, dotar os alunos de habilidades variadas para, à medida que expandem seu repertório de conhecimentos, aprender a fazer relações entre textos e fatos, textos e textos, textos e autores (em seus papéis sociais), textos e momentos históricos. Extrapolando o limite da forma do texto verbal ou multimodal (constituído por mais de um tipo de linguagem) em direção ao contexto cultural e circunstancial, o leitor passará, enfim, a ser expectador, com habilidade para antecipar sentidos, identificar pistas de significações, prever conclusões, associar ideias, entender metáforas, enfim, fazer as inferências necessárias para o cálculo da interpretação. Para compreender, basta conhecer o código material (a língua, a escrita das palavras, as imagens, os gestos, as cores, os balões dos quadrinhos etc.), mas, para interpretar, é preciso conhecer o código social, os comportamentos, os rituais de comunicação, os papéis assumidos pelos falantes, o momento histórico em que se insere o texto, o grupo social em que o texto circula, os outros textos evocados naquele que se lê, enfim, os dados extratextuais que impõem uma configuração específica para cada texto a fim de atingir um objetivo pré-determinado por quem o produz.

Partindo-se do pressuposto de que "a leitura do mundo precede sempre a leitura da palavra e a leitura desta implica com a continuidade da leitura daquele", máxima defendida por Paulo Freire em seu sempre atual 
A importância do ato de ler (2008, p.9), parece plausível fazer, pelo menos, duas afirmações: i) a interpretação competente exige uma habilidade específica quanto à relação entre o texto lido e o universo de referências acionado pelo que é dito nele explícita ou implicitamente e ii) o conhecimento prévio armazenado na memória desde nosso primeiro contato com o mundo é a base de todo o processo de interpretação. As referências expostas por expressões nominais, no texto verbal, ou por meio de imagens figurativas, no texto imagético, por exemplo, indicam explicitamente personagens, lugares, eventos reconhecíveis pelo leitor, com base em suas memórias. No entanto, outras personagens, outros lugares e outros eventos podem ser evocados indiretamente por essas mesmas expressões nominais ou figuras, seja por meio de metáforas (inclusive visuais), seja por meio de elementos que lembram outros textos ou discursos. Quando isso ocorre, há implicitação de conteúdos que precisam ser extraídos do texto por um cálculo interpretativo, a partir de uma inferência acionada por um elemento explícito na superfície textual.

Por exemplo, é comum a referência a políticos com a utilização da figura de Pinóquio (protagonista de um conto infantil, em que, sendo um boneco de madeira, via seu nariz crescer quando contava uma mentira), a fim de indicar uma característica infelizmente muito comum entre a classe e o personagem: ser mentiroso. Designando-se algum político como "Pinóquio", ou substituindo, em uma imagem, o nariz de um político por um de madeira, estão automaticamente convidados, para a teia significativa do texto, outros textos, outros personagens, outras situações que ajudam a expressar um ponto de vista, em uma descrição perspectivada que leva em conta conhecimentos extratextuais e avaliações sociais sobre personagens-políticos relevantes para o sentido global. É preciso, portanto, conjugar a leitura da palavra, no texto verbal, e de outras linguagens, como a imagética, em textos multimodais, com a leitura de mundo, com as experiências acumuladas durante toda a vida do leitor que, associadas aos elementos que constituem os textos, permitem o alcance dos sentidos que estão apenas indicados em sua superfície, mas não explícitos.

A máxima de Freire, entretanto, não se refere apenas à capacidade de associar elementos explícitos nos textos a conhecimentos localizados fora dele e necessariamente trazidos à lembrança do leitor por meio do texto, 
que testemunha o compartilhamento dessas ideias por parte do autor. Além disso, com essa máxima, o educador enfatiza a importância da palavra escrita (e, acrescenta-se, de todo material simbólico circulante na sociedade) como recurso fundamental para o alargamento do repertório do leitor, para acesso a novos conhecimentos, como fonte de informações e de impressões trazidas por outras pessoas, outras culturas, outros pontos de vista que o leitor somará a suas experiências de vida e ao conhecimento adquirido por outros meios, formalizado na escola ou não. A leitura de mundo se enriquece, portanto, da leitura da palavra e de outras linguagens associadas a ela. Mas a leitura de texto sem leitura de mundo nunca será completa.

Define-se então o ato de ler como um processo interativo de construção de sentido, baseado na criação de expectativas concernentes aos saberes partilhados pelos interagentes de uma troca comunicativa estabelecida por meio de um texto. $\mathrm{O}$ sentido é construído nas relações entre texto e contexto, entre produtor e leitor e, enfim, entre o que está explícito no texto e o que é evocado. Em suma, o ato de ler exige do leitor capacidade de criar expectativas e de estabelecer relações.

Para a leitura multimodal focalizada nesta aula, precisaremos observar as estratégias que se relacionam à interação entre o texto apresentado e o mundo que o cerca, que nos cerca. Além disso, outros recursos intratextuais e extratextuais também serão mencionados, a fim de se compor um quadro de estratégias interpretativas que possa orientar o mediador de leitura na tarefa de dar consciência a seu aluno, leitor iniciante, das habilidades que precisa desenvolver, a fim de se tornar um leitor autônomo, competente e crítico. Com esse intuito, este capítulo estará dividido entre três seções, de acordo com as três competências de linguagem, utilizadas pelo leitor no processo de construção de sentido textual, fundamentadas nos postulados da Teoria Semiolinguística de Análise do Discurso (CHARAUDEAU, 2008): a competência semiolinguageira, a competência discursiva e a competência situacional. Mesmo empregadas em um único movimento de leitura, aqui elas serão observadas separadamente para fins analíticos. São essas competências que devem embasar atividades de interpretação de texto mediadas pelo professor. 


\section{A competência semiolinguageira e a multimodalidade verbo-visual}

A competência semiolinguageira diz respeito à habilidade de compreender os signos que compõem a superfície do texto, sejam eles verbais ou não verbais, e sua organização. Essa competência concerne, prioritariamente, ao entendimento do léxico e àquilo que as imagens representam; ao reconhecimento dos referentes (localizados no mundo e/ou em outras parcelas do mesmo texto), das ligações coesivas e das conexões entre as partes (temporais, causais, condicionais, conclusivas etc.), que permitem a progressão das ideias.

É preciso considerar que, mesmo quando lemos um texto exclusivamente verbal, são mencionados outros códigos por meio dos quais entendemos o que o texto diz, como, por exemplo, a descrição do gesto de um personagem que demonstra, em si mesmo, seu estado de espírito, ou de sua expressão fisionômica ou de sua vestimenta, ou mesmo algum recurso tipográfico, como a escrita em caixa alta, que pode implicar a expressão de um tom áspero. São códigos paralinguísticos que estão o tempo todo adicionando sentidos ao que está sendo dito pelas palavras. Isso mostra que as palavras não estarão sozinhas no processo de significação, pois só funcionam amparadas por aquilo que significam e por aquilo que evocam, incluindo nisso outros códigos. Em contrapartida, quando lemos imagens, também é preciso considerar que elas guardam em si, além da capacidade referencial que nos leva a compreender o que elas indicam no mundo, uma forte ligação com categorias e conceitos anteriormente recortados da realidade por meio da palavra.

É preciso salientar que a visualidade, em sentido amplo, é composta por elementos apreendidos pela visão, seja em uma experiência direta com o mundo, seja em uma relação intermediada por imagens, produzidas pelo homem, que representam o mundo, ou seja, pela linguagem visual, e pode ser tomada como um Sistema Imagético composto por outros sistemas (como a Cinésica, os Sistemas Cromáticos, a Indumentária, o Design) e pelos sistemas enunciativos (meramente visuais, ou verbo-visuais) ad hoc, que se atualizam nos textos puramente imagéticos ou verbo-visuais e 
suscitam uma sintaxe visual de acordo com as recorrências e as convenções relacionadas a cada gênero.

O Sistema Imagético é, então, formado por signos cujo significante é da ordem do visual e cujo significado depende, em alguma medida, da iconicidade, i.e., de uma relação motivada (pela semelhança, ou coincidência de uma qualidade) entre significante e significado, ou, nos termos de Peirce (2003), entre signo e objeto. Embora a função primordial da imagem seja indicar uma referência, ela alça o caráter simbólico ao ultrapassar a simples referencialidade, ou seja, à medida que se torna convencional e incorpora valores ao signo, afirmando seu caráter representacional.

Nos cartuns criados pelo argentino Quino, por exemplo, são usados personagens bastante estereotipados que representam parcelas sociais específicas: homens de batina representam a Igreja; mulheres de salto alto e joias, ou homens de terno, gravata e chapéu, em referência à classe dominante. Igreja e classe dominante são, dessa forma, indicadas por meio de representações metonímicas que traduzem, em imagens figurativas, conceitos anteriormente especificados por palavras. Embora se trate de um tipo de convenção diferente daquela experimentada pela palavra no sistema linguístico, a metonímia visual consegue expressar, por causa de sua recorrência e da percepção de aspectos apreendidos pela visão, o mesmo significado de uma expressão nominal.

Outro aspecto relevante observado na atuação da competência semiolinguística diz respeito a parcelas textuais constituídas por signos verbais e visuais em integração. Nesse caso, a referenciação operada pelo texto verbo-visual utiliza o amálgama das duas vias de acesso ao mundo como recurso representativo conjunto, também observado em distintos graus de integração. No livro ilustrado O homem que amava caixas (KING, 2017), por exemplo, vê-se, logo na imagem da capa, um homem adulto que segura um avião feito de caixa de papelão no alto de um monte, de frente para o leitor. Em segundo plano e bem abaixo dele, um menino, de costas para o homem e para o leitor, brinca de pipa ao lado de seu cãozinho. Essa configuração em planos representa o protagonismo do homem na narrativa e o tema do livro: a difícil aproximação entre o pai e o filho, que acaba acontecendo por 
meio dos objetos feitos de caixas pelo pai. Na camada mais superficial do texto, a observação da disposição dos elementos imagéticos em planos distintos, do distanciamento físico correspondente ao distanciamento pessoal, em conjunto com o título e a narrativa verbal, repercute, ao longo da leitura, em outros sentidos e percepções.

A relação verbo-visual mais integrada pode ser analisada, por exemplo, em tirinhas e histórias em quadrinhos, pela própria codificação desse tipo de narrativa - entre outras ali presentes. A disposição das ações em quadros sequenciais precisa ser reconhecida como um espelhamento da cronologia dos fatos na experiência humana. Quase sempre a imagem de um personagem se repete em vários quadros com alguma alteração, a fim de se relatar uma transformação ocorrida pela ação desse actante. A repetição mostra-se essencial para a manutenção do tópico discursivo. Os balões indicam as falas, sussurros, pensamentos, e aquilo que é dito ganha sentido específico em função do que é identificado por meio da imagem, em substituição das descrições verbais: personagem, ambiente, fisionomia, vestimenta etc.

Como ilustração, descrevemos, a seguir, o conteúdo de uma tirinha do site Will Tirando ${ }^{2}$. Nesse texto, o personagem aparece em uma atitude despojada, com mãos nos bolsos, e aparência condizente com a classe média brasileira, blusa de gola e mangas compridas, cabelo curto, sem barba. Permanece assim em quatro dos cinco quadros, em uma sequência que codifica a passagem de tempo e o foco naquilo que ele diz: "Nada contra esse tipo de gente, mas...”. A suspensão da fala indicada pelas reticências é acentuada pelo fundo negro do quadro seguinte, assim como pela paralisação do homem. Como elemento coesivo, a conjunção "mas" inicia a parcela da frase que se opõe à anterior, criando a expectativa de que aquilo dito depois dela invalide o que se disse antes, em uma atitude bastante comum, reveladora de preconceito. Nos quadros seguintes, o homem se corrige, retirando da frase a oposição quase dita. No último quadro, a imagem de Deus, de camisolão, barbas brancas e longas, ao lado de um anjo, em cima de nuvens, empunha uma chave de fenda, provavelmente retirada da mala de ferramentas a seus

\footnotetext{
${ }^{2}$ Disponível em http://www.willtirando.com.br/page/2/ - Acesso em: 28 out.218.
} 
pés, que diz, com as mãos nas "cadeiras", sinalizando finalização de uma atitude: "Prontinho! Corrigido!". Com os olhares dos dois personagens voltados para baixo, provavelmente para nosso mundo, entende-se que Deus se referia ao homem e evita a atitude preconceituosa graças à sua interferência, metaforizada em conserto com ferramentas.

Nessa tirinha, temos, portanto, uma relação verbo-visual bem integrada, com elementos visuais facilmente reconhecíveis a partir do imaginário partilhado pelo autor e pelos leitores (o homem e sua identidade, Deus e seu papel regulatório etc.), assim como elementos verbais que indicam um grupo social diferente daquele do personagem ("dessa gente”) e o prenúncio de uma atitude preconceituosa ("mas..."). São todos elementos da superfície textual indicadores de seres e fatos do mundo (real e imaginário), além da codificação própria de tirinhas (com quadros em sequência e balões de fala), também necessariamente reconhecida, a fim de que se construa a narrativa.

$\mathrm{Na}$ mediação realizada pelo professor, esses elementos superficiais precisam ser destacados e identificados um a um pelos alunos-leitores, a fim de se mostrar que a construção do sentido global do texto depende do reconhecimento de elementos do mundo real ou imaginário e de outros códigos agregados. É preciso mostrar como o sentido do texto é construído aos poucos, muito mais do que mostrar o que é dito simplesmente.

A competência semiolinguageira permite, portanto, o reconhecimento de recortes da realidade por meio do signo, seja verbal, seja imagético, seja verbo-visual. É essa competência que atua nas inferências relacionadas à coesão, aos raciocínios lógicos e aos conteúdos pressupostos. Na superfície do texto, observa-se, como ensina a Teoria Semiolinguística, a transformação de um mundo a ser significado em mundo significado envolta em signos que se organizam em uma conformação igualmente cheia de sentidos. O processo de transformação permite colocar em cena uma descrição em perspectiva, um modo de apresentar - e, por parte do leitor, de perceber - um recorte da realidade impregnado de conhecimentos partilhados pelo grupo em que o texto circula. Essa transformação significativa, porém, ocorre pelas restrições advindas do discurso e, para finalização do sentido, das circunstâncias enunciativas, como veremos a seguir. 


\section{A competência discursiva e o conhecimento prévio}

Para além da superfície do texto, da compreensão dos signos e de sua combinação, é preciso observar as pistas que levam a dados extratextuais armazenados na memória e não explicitados no texto, tanto da ordem dos mecanismos enunciativos, quanto da ordem dos saberes de conhecimento e de crença. No primeiro caso, observa-se não só o modo como são colocados enunciador, enunciatário e aquilo/aquele de quem se fala, mas também o modo de organização do discurso predominante: descritivo, narrativo ou argumentativo. São modos que levam a atitudes enunciativas diferentes, correspondentes a intencionalidades igualmente diversas.

Assim, quando o texto apresenta, em sua superfície, elementos que indicam a centralidade da primeira pessoa do discurso, nota-se maior engajamento do enunciador em relação ao que ele diz; quando o texto está centrado na segunda pessoa, percebe-se um maior investimento no enunciatário, transferindo-se para ele a necessidade de adesão ao dito; quando está centrado na terceira pessoa, há um distanciamento maior dos interlocutores em relação ao dito.

Além disso, se há predominância do modo descritivo em um texto ou em uma parcela de um texto, sabemos que o descritor pretende mostrar o mundo sob sua perspectiva, buscando representar os seres e as coisas de acordo com seu olhar e com um intuito específico. Se há predominância do modo narrativo, o que se apresenta ao leitor é um acontecimento, a ação de um personagem em busca de uma solução, do preenchimento de uma falta. Se há predominância do modo argumentativo, há uma evidente busca de persuasão do interlocutor em prol de uma tese defendida pelo produtor.

Cada um desses modos apresenta elementos semiológicos característicos, assim como objetivos próprios, em função de uma intencionalidade inscrita textualmente. Outro aspecto é o acionamento de saberes de conhecimento e de crença, isto é, do conhecimento prévio que se julga que o leitor domina e das crenças que provavelmente tem, com suas devidas avaliações dos fatos, dos comportamentos, das pessoas. Na percepção desses elementos, apreende-se não só um modo de dizer, mas, sobretudo, a intenção daquele 
que produz o texto. Em uma atitude leitora consciente, observam-se os elementos textuais da superfície como "pistas" para desvelar estratégias de engajamento e de revelação da realidade que extrapolam a explicitude do texto, ou seja, estão meramente implícitos, prontos para a inferência do leitor. Em outras palavras, a competência discursiva está vinculada à habilidade de o leitor relacionar texto, recursos discursivos e contexto cultural.

Em relação aos textos multimodais verbo-visuais, constituídos por, além das palavras, elementos figurativos que agem em ambientes reconhecíveis pela visualidade, o modo narrativo se mostra predominante na superfície. A mostração de seres, ambientes e fatos, isto é, a identificação e qualificação desses elementos por meio de imagens (e não de palavras, quase sempre), característica do modo descritivo, age a serviço do narrativo, geralmente apresentando figuras bastante estereotipadas, ou caricaturas, ou imagens representativas bem semelhantes à realidade (como nas fotografias, por exemplo). Além disso, gêneros discursivos verbo-visuais como charge, cartum, tirinha, histórias em quadrinhos, contos ilustrados, entre outros, prestam-se, quase sempre, à crônica, ou à crítica social. Dessa maneira, deve-se também avaliar o caráter persuasivo desses gêneros multimodais, revestidos de uma narração "alegórica", a serviço da defesa de uma opinião, ou de uma questão de cunho social. Dessa maneira, os modos de organização do discurso se entrelaçam e deixam pistas interpretativas muito úteis para formulação de atividades de mediação por parte do professor.

Em outra tira ${ }^{3}$, duas pessoas contemplam o sol se pondo numa praia. O momento bucólico é interrompido pelo comentário de uma delas: "Ainda acho o 'Retorno de Jedi' melhor que 'O império contra-ataca". À guisa de título, apenas posposto à direita da cena, o enunciado "1000 maneira de estragar o pôr do sol" ancora a interpretação, um tanto difusa quanto à avaliação da frase emitida pela personagem. No circuito interno do texto enunciado, em que agem personagens, mostra-se, em terceira pessoa e, portanto, sem engajamento explícito do autor, nem implicação direta do interlocutor, um acontecimento trivial e inusitado. No circuito externo,

3 Disponível em : https://www.facebook.com/malvadoshq/fotos/a.181209315329627/ 1869215136529028/?type=3\&theather - Acesso em: 28 out.2018. 
onde se posicionam autor e leitor, observa-se a defesa de uma opinião: falar de filmes (ou desses filmes) estraga o momento contemplativo do pôr do sol. A cena narrativa, então, esteve a serviço da argumentação.

Só alcança o sentido final desse texto o leitor que reconhece, na intertextualidade estabelecida por meio das expressões nominais proferidas pela personagem, dois filmes de grande circulação, e relaciona a cena com o título-comentário à direita (já mais próximo da atitude argumentativa). $\mathrm{O}$ autor emite sua opinião por meio dessa breve narrativa, cheia de lacunas interpretativas que devem ser preenchidas pelo leitor. Subentendida na opinião expressa pela forma como foi elaborada a tira, pode-se inferir, por indução, que a pessoa que faz esse tipo de comentário em momentos como esse é alguém desagradável. Nesse caso, é a competência discursiva que leva o leitor a fazer inferências relacionadas ao meio cultural em que vive, aos comportamentos sociais, às avaliações que o grupo faz diante da realidade, à formulação indireta de ideias. Trabalhar as pistas textuais que levam a elementos extratextuais avaliados socialmente, na mediação com o aluno, permite o desenvolvimento da habilidade de relacionar texto e contexto cultural e, dessa relação, provocar as inferências necessárias à construção de sentido.

Um aspecto bastante relevante a ser observado em textos imagéticos ou verbo-visuais é a codificação impregnada nas imagens, alçando-as a signos mais convencionais, apesar de sua iconicidade característica. É uma codificação atrelada ao conhecimento cultural, às representações sociais, às expressões visuais cristalizadas que fazem parte do imaginário sociodiscursivo. Considera-se codificada a imagem que representa, de modo sintético, uma ideia muito disseminada socialmente, facilmente reconhecível quando utilizada no seio de um grupo de partilha. Por seu caráter convencional, é considerada signo completo.

Há diferentes graus de abrangência da imagem codificada de acordo com sua maior ou menor representatividade. Por exemplo, a suástica representa o nazismo; a cruz, o cristianismo; o par de listas verde-amarelo, a brasilidade; a placa redonda vermelha com uma barra branca horizontal, contramão; os balões das histórias em quadrinhos, o discurso direto. São imagens com alto grau de codificação. Outro tipo de imagem codificada são as imagens-sintoma (CHARAUDEAU, 2013), que representam fatos 
de forte apelo afetivo e se fixam na memória de gerações, como as tatuagens nos braços dos judeus em campos de concentração; a imagem da explosão da bomba de Hiroxima; o avião que crava nas Torres Gêmeas; o bebê refugiado morto na beira da praia. Além de significarem algo, estão carregadas de emoção. Outras dependem igualmente da evocação das circunstâncias em que foram captadas e que passam a representar, mas são menos abrangentes, como a imagem de um vampiro vestido de terno, com a faixa presidencial brasileira, em referência ao presidente da república, ou de uma ala inteira fantasiada de pato de borracha manipulado por uma imensa mão, como marionete, em referência aos que protestaram a favor do impeachment da presidenta Dilma, ambas no desfile de 2018 da Escola de Samba carioca Paraíso do Tuiuti. Da mesma forma que a imagem-sintoma, essas outras imagens altamente codificadas dependem do conhecimento prévio acerca de acontecimentos mais ou menos universais, que causaram uma resposta avaliativa da sociedade. São codificações que necessitam de repertório visual e histórico por parte do leitor e designam pessoas e fatos mais ou menos diretamente.

Mais um aspecto interessante: na imagem, sobretudo naquela que pode ser manipulada (com enquadramentos inusitados, ou com trucagem, ou com ilustrações estilizadas), a construção de metáforas é muito produtiva. Nesse caso, há sobreposição de signos e de sentidos em um processo de síntese que depende de um cálculo de sentido voltado para a observação de uma qualidade comum aos elementos sobrepostos ou aproximados a fim de provocar um novo sentido. Por exemplo, circulou pelas redes sociais a fotografia de um cartaz de rua, daqueles de propaganda, de duas bandas apoiadas no chão, com a imagem de um cachorro urinando na boca aberta de um político, que parecia falar algo. A boca, assim tomada como latrina, pode ser interpretada como um lugar próprio (apenas, ou principalmente) para porcarias; dessa maneira, aquilo que um político fala é igual a excremento; é ruim, sujo, sem valor. A imagem do político se alternou com a de outros, tendo sido mantida a qualidade comum de serem pessoas que só falam bobagens e que não merecem muito respeito por esse motivo.

Quando há a aproximação de elementos a partir de uma qualidade comum que se deseja exacerbar, ou sobreposição de figuras com esse mesmo 
fim, ocorre o processo metafórico tal e qual quando dizemos "Essa pessoa é uma flor!" ou “Esse político só fala m...”. Superficialmente, há uma incongruência, pois um ser humano não pode se transmutar fisicamente em uma flor, ou falar expectorando fezes. Exige-se, portanto, um cálculo de sentido para que se perceba a qualidade da flor que combinaria com a pessoa a quem se refere a afirmação (a delicadeza singela) ou a característica da fala do político que a assemelha a fezes (sua sujidade, ainda que moral).

Em outro texto, sob o título "O Brasil visto de cima"4, o mapa do país parece delinear as bordas de um buraco sem fundo. Essa condição não corresponde, fisicamente, à imagem do Brasil, convencionalmente reconhecido pelo mapa, no continente, ou no planeta. Assim, em um cálculo de sentido, a qualidade exacerbada na imagem pode ser a de um país "afundado" em problemas insolúveis, ou a de um país "extraído", "roubado" de seu lugar. Ambas as ideias são metaforizadas pelo buraco sem fundo.

Ainda no âmbito da competência discursiva, inclui-se a capacidade de identificar axiologias, ou, em outras palavras, valores socialmente instituídos a respeito da realidade (ou das realidades). Trata-se especificamente de uma competência igualmente vinculada ao discurso, mas orientada pelo sistema de crenças que o grupo de partilha domina. Por exemplo: recentemente, nas redes sociais, circulou um texto composto por um par de fotografias semelhantes, nas quais se viam crianças encarceradas. Como legenda da primeira, lia-se: “Germany, 1944”. Da segunda: “America, 2018”. Para quem acompanhava os noticiários, a segunda fotografia estava relacionada à nova política anti-imigração proposta nos Estados Unidos pelo Presidente Trump, que separou crianças, filhas de imigrantes, de seus pais, como método para inibir a entrada de estrangeiros no país. Com a aproximação, deu-se a comparação da atitude americana com aquela dos nazistas na $2^{\text {a }}$ Guerra Mundial, que também separaram pais e filhos, e, a partir disso, a avaliação negativa quanto à atitude do presidente, considerado tão cruel quanto um nazista. Com a competência axiológica, compreende-se a crítica contida no texto, baseada em uma opinião e em um forte sentimento partilhados socialmente.

\footnotetext{
${ }^{4}$ Disponível em: https://www.facebook.com/malvadoshq/photos/a.181209315329627/ $1866390173478191 /$ ?type $=3 \&$ theater - Acesso em: 28 out.2018.
} 
Apesar de a verbo-visualidade constituir uma materialidade complexa, com recursos significativos diversos, cujo acesso ao mundo extratextual se realiza de modos diferenciados, o discurso, da ordem da imanência - e não da manifestação, como é o texto (FIORIN, 2012, p.148) -, composto por ideias, ideais e memória, permanece um só, unindo saberes organizados em rede e evocados por um interminável processo associativo, que inclui a capacidade avaliativa com base em opiniões coletivas.

Entretanto, há outro tipo de contexto, mais imediato, que direciona a interpretação de acordo com a observação da enunciação, isto é, do ambiente em que o texto é produzido, lido, enunciado, e dos interlocutores, em seu papel social, colocados em interação. A esse contexto concerne a competência situacional, como veremos a seguir.

\section{Competência situacional e o comportamento dos interlocutores}

A competência situacional ou praxeológica (EMEDIATO, 2007) se refere, sobretudo, à habilidade de o leitor identificar de onde se fala e para quem se fala. Todo texto, do oral ao escrito, do puramente verbal, ou imagético ou verbo-visual, mostra, inscrito nele, um enunciador, como um desmembramento do produtor, sujeito extratextual que pode se engajar mais ou menos em sua enunciação. Ao mesmo tempo, todo texto mostra, igualmente inscrito nele, um destinatário próprio, com quem o leitor "real" pode ou não se identificar. A análise desses sujeitos e da identidade que apresentam pode criar expectativas quanto aos sentidos e efeitos emanados pelo texto. Espera-se algo do texto justamente porque apresenta este ou aquele tipo de sujeito inscrito nele.

Por exemplo, um dos primeiros textos de campanha contra a contaminação de HIV foi um vídeo produzido pela TV Cultura em que o escritor Plínio Marcos, ele mesmo, se dirigia a detentos numa cadeia, utilizando uma linguagem em uma variedade bastante popular, cheia de gírias e palavrões, para mostrar a necessidade de se usar preservativo em qualquer relação sexual e não utilizar uma mesma seringa na injeção de drogas. É um texto pesado e realista, bem objetivo, em uma campanha publicitária que não poderia, por exemplo, ser veiculada pela televisão, para a grande massa. Reconhece-se 
assim a especificidade de um enunciador engajado, falando como ele mesmo, com linguagem acessível à maioria dos detentos (quase sempre de origem pobre, com pouca escolaridade e um dialeto próprio), a fim de convencê-los de uma ideia. Os destinatários do vídeo são os detentos, aqueles a quem aquela linguagem faz sentido e está totalmente apropriada, mas não o público da TV, cuja expectativa de destinação é mais ampla e constituída por famílias que abominariam aquele modo de dizer. Se fosse veiculada pela TV, o telespectador provavelmente não aderiria à proposta de destinatário e não responderia como o público idealizado para receptor daquela propaganda.

Todo texto, então, pressupõe sujeitos interagentes próprios. Esses sujeitos são cônscios de um contrato comunicativo que se estabelece quando é utilizado um determinado tipo de texto em um determinado ambiente (contexto imediato) ajustado a papéis sociais. Nesse contrato, o leitor age de acordo com a proposta inscrita na materialidade textual. $\mathrm{Na}$ interação face a face, esses papéis e comportamentos interpretativos são suscitados pelo momento e lugar da interação, assim como pelos papéis sociais exercidos pelos interagentes (por exemplo, na sala de aula, entre professor e aluno; no bar com amigos; entre avô e neto etc.). Já na interação postergada, aquela que se completa em um momento diferente do da produção, o contrato é reconhecido pelo gênero discursivo utilizado e pelos suportes em que estão inseridos os textos. Por exemplo, no caso dos textos multimodais verbo-visuais, não se lê da mesma maneira uma charge na revista semanal e um livro ilustrado para crianças, nem uma fotolegenda de capa de jornal, ou um cartum em um livro didático. Cada contrato cria expectativas de leitura diferentes, com comportamentos de leitura e objetivos também diferentes.

Veja a falha de comunicação - que dá o tom engraçado - no circuito interno do diálogo a seguir, no contrato estabelecido por uma mulher adulta (indicada apenas por uma saia e por um par de saltos altos) e Armandinho, o protagonista da tirinha. A mulher adulta se dirige à criança: "Armando, como você cresceu! Já tem namorada?". Ele responde: "Não! Nem quero. Por que não procura alguém de sua idade?”'

\footnotetext{
${ }^{5}$ A tira está disponível no site: https://www.facebook.com/tirasarmandinho/photos /a.488361671209144/1981334671911829/?type=3\&theater.
} 
Considerando-se a identidade da mulher adulta, o entendimento da intenção daquela pergunta seria a de expressar que o menino havia crescido tanto que estaria na idade de namorar, mas não necessariamente que a mulher poderia ser sua namorada. Ou ainda, que seria um bom candidato para namoro, mas em tom de brincadeira. Ignorando a identidade social da enunciadora e a sua própria, o menino se equivoca, pensando que aquele seria um pedido real de namoro. A falha na comunicação houve por não ter sido obedecido o papel presumido para aqueles interagentes, isto é, o de tomar a expressão como uma exclamação sobre o crescimento do menino, ou como brincadeira, em virtude de suas identidades de adulto e de criança. Por outro lado, observando-se o circuito estabelecido entre cartunista e leitor, além de a tirinha revelar a espontaneidade das crianças, também lança um alerta a respeito de possível assédio da pedofilia, tão em voga no momento. Se o leitor já conhece a tirinha de grande circulação nas redes sociais, sabe que pode criar a expectativa de um tema "politicamente correto", sendo essa pressuposição também ancorada na externalidade do texto, em seu contexto imediato, no contrato estabelecido por esse gênero discursivo e por esse suporte nas redes sociais.

Para finalizar, pode-se sintetizar a competência situacional como aquela que permite a interpretação de um texto em função dos sujeitos envolvidos na troca comunicativa e em uma espécie de contrato estabelecido entre eles por meio do próprio texto, configurado de acordo com um gênero discursivo partilhado socialmente. Ao detectar o gênero (quase sempre por suas características formais), o leitor reconhece as possibilidades de leitura: a temática permitida pelo gênero; a intencionalidade própria daquele tipo de texto; quem pode ou deve enunciá-lo; se é ou não possível intervir em sua construção; o que se pode esperar em termos de engajamento do produtor em relação ao que é dito. É essa competência que finaliza o sentido do texto de acordo com os ajustes feitos pelas circunstâncias da enunciação. $\mathrm{Na}$ transação interlocutiva entre os sujeitos, o processo de transformação de um mundo a significar em mundo significado se realiza, dando sentido ao texto e à vida. 


\section{Exercícios}

1. Explique a diferença entre compreender e interpretar um texto.

2. Defina e explique o ato de ler.

3. Em que tipo de habilidades se baseia a competência semiolinguageira? Explique.

4. Descreva o texto multimodal verbo-visual.

5. Em que tipo de habilidades se baseia a competência discursiva? Explique.

6. Relacione a imagem codificada e o conhecimento prévio necessário para a interpretação.

7. Em que tipo de habilidade se baseia a competência situacional? Explique.

8. Explique a importância da observação do contrato comunicativo na interpretação dos textos.

\section{Resumo}

Neste capítulo, a partir da conceituação de ato de ler, procuramos mostrar a diferença entre compreender e interpretar, sobretudo em relação ao texto multimodal verbo-visual, a fim de explorar estratégias leitoras. Essas estratégias estão baseadas em três competências para construção de sentido textual: a competência semiolinguageira, centrada na composição formal dos textos e seus recursos de coesão; a competência discursiva, voltada para o repertório cultural necessário para a construção do sentido, baseado em saberes de conhecimento e de crença, além de alguns recursos discursivos, como os modos de organização do discurso: descritivo, narrativo e argumentativo e a competência situacional, responsável pelo acionamento e reconhecimento dos papéis representados pelos sujeitos das trocas comunicativas e das circunstâncias em que elas se dão. Pelo desenvolvimento dessas competências, acredita-se que o leitor adquira habilidades diversas para a interpretação autônoma de textos.

Quanto aos textos multimodais verbo-visuais, destacam-se, neste capítulo, alguns aspectos que, por um lado, os diferenciam em termos 
formais dos textos puramente verbais, mas que, por outro, os igualam em termos discursivos, já que várias estratégias leitoras dependem de um repertório cultural necessário à construção do sentido de qualquer tipo de texto, pois, mesmo sendo acionado por elementos pertencentes à sua superfície, é bagagem guardada na memória, pertence ao universo extratextual, e deve ser utilizado para preencher lacunas interpretativas deixadas pela palavra ou pela imagem.

A passagem de espectador a expectador estará completa quando o leitor, consciente das estratégias de leitura, começar a ter autonomia para perceber as pistas deixadas na superfície do texto e fazer inferências baseadas nos saberes prévios, acumulados ao longo da vida. Ao aprender a criar expectativas, o leitor investe sua subjetividade na construção do sentido textual, ultrapassando o óbvio e o explícito na direção do sugerido e do implícito. Torna-se, então, um leitor competente.

\section{Referências}

CHARAUDEAU, Patrick. Linguagem e discurso: modos de organização. São Paulo: Contexto, 2008.

CHARAUDEAU, Patrick. Imagem, mídia e política: construção, efeitos de sentido, dramatização, ética. In: MENDES, Emília; MACHADO, Ida Lucia; LIMA, Helcira; LYSARDO-DIAS, Dyllia. Imagem e discurso. Belo Horizonte, MG: Fale/UFMG, 2013. (p. 383-405)

EMEDIATO, Wander. Contrato de leitura, parâmetros e figuras do leitor. In: MARI, Hugo; WALTY, Ivete; FONSECA, Maria Nazareth (Orgs.). Ensaios sobre leitura 2. Belo Horizonte, MG: Editora PUC Minas, 2007. (p.83-98)

FIORIN, J. L. Da necessidade de distinção entre texto e discurso. In: BRAIT, B.; SOUZA-E-SILVA, M. C. (Orgs.) Texto ou discurso? São Paulo: Contexto, 2012.

FREIRE, Paulo. A importância do ato de ler: em três artigos que se completam. 49a ed. São Paulo: Cortez, 2008.

KING, Stephen Michael. O homem que amava caixas. 2.ed. São Paulo: BrinqueBook, 2017.

PEIRCE, Charles Sanders. Semiótica. 3. ed. São Paulo: Perspectiva, 2003. 


\section{PROCESSOS DE CONSTRUÇÃO DE TEXTOS NA ESCOLA: AFINAL DE CONTAS, QUEM SABE ESCREVER?}

Fabio André Coelho (UFF)

\section{Objetivos}

Ao final deste capítulo, você deve ser capaz de compreender..

- As condições das produções de textos reais de nossos alunos;

- O trabalho interativo da produção de textos e da leitura para a análise linguística;

- O processo de construção dos textos dos alunos e as operações envolvidas;

- As etapas de leitura das produções escritas por parte dos alunos, com o objetivo de realizar a revisão.

Se o objetivo é que o aluno aprenda a produzir e interpretar textos, não é possível tomar como unidade básica de ensino a letra, nem a sílaba, nem a palavra, nem a frase que, descontextualizadas, pouco têm a ver com a competência discursiva, que é a questão central. Dentro desse marco, a unidade básica de ensino só pode ser o texto (BRASIL, 1998, p. 29).

\section{Introdução}

Pensar em uma língua é pensar também nas suas variações, no olhar de quem a escreve, no que se escreve sobre ela, no que se pensa sobre o que vai escrever dela, nas maneiras de representá-la, no toque peculiar de cada usuário. Falamos de uma língua totalizante, repleta de significações e jeitos de ser mostrada e, mesmo assim, ainda estamos longe de termos uma completude no que tange à modalidade escrita. Quando falamos em completude, pensamos exatamente no mosaico de diferenças de usos que 
nos levará à grandeza do texto escrito. Por outro lado, ainda hoje a escola se restringe ao que diz respeito à uniformidade das palavras, em um mundo cheio de regras e convenções, de esquemas prontos.

Devemos ter olhos atentos para os momentos de aprendizagem, observando cada universo singular dos nossos alunos, e mediá-los com relação aos instrumentos linguísticos que podem ser utilizados nas suas produções textuais. Cada aula deve ser um momento de descoberta e de escolhas. O texto está ali, pronto para ser feito, e o aluno transbordante de ideias e "causos". É o momento de deixar fluir o pensamento e se desprender daquilo que disseram ser "benéfico" para uma "boa" produção escrita. A língua está a nosso serviço; não pode ser o contrário.

Cada situação interacional revela uma modalidade de variação escrita, de acordo com os objetivos e as intenções do usuário. Nesse sentido, Irandé Antunes (2003, p. 209) nos diz que:

Com efeito, escrever é, simultaneamente, inserir-se num contexto qualquer de atuação social e pontuar nesse contexto uma forma particular de interação verbal. Daí que, além das determinações do sistema linguístico, a interação verbal por meio da escrita está sujeita também às determinações dos contextos socioculturais em que essa atividade acontece.

Todo texto tem a sua particularidade criada e tratada na multiplicidade de recursos que se apresentam por meio dos contextos. É preciso entender que cada situação comunicativa fará o produtor de textos escolher o gênero mais apropriado, a fim de atingir seus objetivos interativos, elocutórios. Assim também acontece com as marcas linguísticas selecionadas pelo usuário da língua. São elas que darão o toque de singularidade e autoria aos textos. É preciso entender que cada gênero textual exigirá uma ou outra ocorrência gramatical, estilística, em função dos contextos onde circulam.

São muitas as operações que se inscrevem nos processos de construções dos textos e devemos estar atentos para que cada uma delas seja do conhecimento dos alunos aprendizes. Não adianta querermos acelerar o processo, quando, na verdade, a aprendizagem é lenta, árdua, mas compensatória. Cada professor precisa entender que o momento de cada 
aluno merece ser respeitado, pois, ao se tratar de produção de textos, não há consenso de um aprendizado "coletivo" e sincrônico. Certo é que devemos direcionar nossos esforços para que as diferenças sejam mínimas, mas definitivamente não há como garantir que todos aprenderão determinado conteúdo ao mesmo tempo.

\section{Um início de conversa sobre Texto e suas implicações pedagógicas}

Para começo de conversa, é preciso que todo professor de Língua Portuguesa entenda que a sua prática docente deve estar alicerçada no texto como objeto de estudo. É claro que jamais devemos descartar os elementos gramaticais, mas a atenção precisa estar concentrada na apreensão dos sentidos e nas sequências discursivas, assim possibilitando uma maior análise das propriedades de textualidade.

Quando caminhamos para essa prática, acabamos por desenvolver ações que nos direcionam para atividades possibilitadoras do desenvolvimento linguístico, cognitivo e contextual (ANTUNES, 2017). Nesse sentido, a tríade pode ser entendida à medida que o aluno compreende as unidades estruturantes da língua, entende os significados das palavras, frases, dos arranjos sintáticos e consegue reunir e aplicar todas essas informações no seu cotidiano, nas suas práticas interativas. Assim, temos um sujeito linguístico inserido em um mundo permeado por sentidos e capacitado para compreendê-los e interpretá-los.

É necessário que tenhamos em mente a teia que se enreda no aprendizado linguístico, fazendo/permitindo que o aluno construa suas histórias, enredos, estabelecendo relações com o mundo que o cerca. Reduzir a aprendizagem da Língua Portuguesa a uma parte da tríade apresentada significa engendrar um estudo menor, sem consistência.

Quando estamos em situação de escrita, pensamos para quem escrevemos, onde estamos, com quem estamos nos comunicando. Isso parece básico, mas, na prática, não é. Ainda vemos muitos professores ensinando uma língua descontextualizada, sem objetivos explícitos para cada situação comunicativa. Isso torna o texto vazio e o discurso sem qualquer significado. Muitas vezes, quando dizemos isso, parece que estamos "chovendo 
no molhado". Entretanto, deve-se investir em uma concepção e consciência de linguagem em uso a reger todo o nosso trabalho docente. Parece até uma "receita de bolo", mas infelizmente não seguida por todos.

Ao professor, cabe perceber que as práticas de análise linguística perfazem a construção de um conhecimento textual que vai além da palavra, da frase, capacitando linguisticamente o aluno e fazendo-o perceber que o mundo da escrita extrapola as palavras, daquilo que ele conhece de mundo e que há muito a se descobrir lexicalmente, semanticamente e pragmaticamente, a cada dia, na sala de aula e fora dela. Por falar nisso, outra questão importante é a sala de aula.

Esse é um lugar encantado, onde os saberes se constroem na diversidade linguística, nos universos particulares que cada um traz e onde se revelam as condições reais de produção de textos dos alunos. Para um toque de realidade quanto às questões estruturais das escolas, das salas de aula, Antunes (2017, p. 162) nos provoca a reflexão:

A própria estrutura das escolas não favorece um trabalho mais centrado na participação efetiva dos alunos, pois nem os professores dispõem de condições favoráveis para planejar e avaliar melhor seu trabalho, nem os alunos, em salas superlotadas, podem fazer atividades que exijam mais concentração e aplicação pessoal, como, por exemplo, produzir, com a desejada assiduidade, materiais que impliquem a efetiva interação oral ou escrita.

Apesar de todo esse contexto de precariedade, é nesses espaços (a escola e a sala de aula) que nos damos conta de que a linguagem é o resultado da interação e ela não é um produto acabado. Daí a necessidade de se buscar novas alternativas para que a aprendizagem linguístico-textual possa contribuir para a formação do cidadão linguístico, ou seja, aquele que conhece sua língua e suas variadas formas de linguagem e a utiliza de modo consciente e produtivamente responsável. Para que a linguagem esteja atrelada de forma eficaz às condições de produção dos textos, devemos levar em consideração alguns aspectos: 
1 - A natureza linguística - Devemos entender que a sociedade, a história e a ideologia constituem essa natureza, por constituir o sujeito como indivíduo. É interessante perceber que a sociedade constrói toda a gama de interações e possui o controle delas e das representações. É um continuum construtivo da língua. À medida que essa condição se torna clara, entendemos a sala de aula como ambiente que deve ser revelador das histórias dos alunos, responsável pela inserção deles no universo cooperacional/interacional e formador de opiniões, ideias e tomadas de posição do/no mundo. No mundo onde vivemos, falar/escrever o que se pensa pode ser perigoso. $\mathrm{E}$ a palavra é o objeto responsável por nos colocar ou nos tirar do perigo. $\mathrm{Na}$ tentativa das várias transformações sociais é que nos arriscamos. Acreditamos que, assim como nos diz Ingedore Koch (2014, p.209), "é preciso que os produtores de texto dominem uma série de estratégias de organização da informação e de estruturação textual”, para que nosso ato comunicativo se realize de forma plena, inteligível, sem ruídos. No fundo, temos uma constatação: aquele que prefere o silêncio tem medo de se expor ou não sabe usar a língua. Eis aqui a nossa tarefa como professores: substituir o medo pela coragem de se expor adequadamente, respeitosamente, utilizando todo o aparato linguístico que está a nosso dispor, pois a língua está a nosso serviço.

2 - A aquisição linguística - Essa precisa ser respeitada como individual e coletiva, revelada pela linguagem oral e escrita, cada uma desenvolvida em "etapas". Entendamos as etapas como tempos e espaços utilizados para a apreensão dessas linguagens. Ressaltamos a necessidade de o professor se colocar como mediador no processo de aquisição da escrita, nos momentos de composições e produções textuais dos alunos. Nesse sentido, Antunes (2009, p. 43) nos faz uma pergunta e nos dá uma resposta que se encaixam em nossa reflexão:

E no âmbito mais especificamente no ensino de línguas, como o professor poderia promover a formação do cidadão?

Primeiramente, estimulando o senso crítico do aluno por meio de múltiplas atividades de análise e de reflexão; instigando a curiosidade, a procura, a pesquisa, a vontade da descoberta, o que implica a não conformação com o que já está estabelecido; desestimulando, portan- 
to, o simplismo e o dogmatismo com que as questões linguísticas têm sido tratadas.

Dessa forma, ao professor é dada a tarefa importante de coordenar esse processo de criação dos alunos e de saber direcioná-los para que os textos contenham os fatores responsáveis pela textualidade (coesão, coerência, informatividade, situacionalidade, entre outros).

3 - A visão de mundo - Por natureza, o homem é um ser social e está inserido em uma sociedade formada por grupos de todas as classes. Cada sujeito inserido no ambiente da sala de aula precisa se conscientizar de que somos capazes de realizar mudanças sociais, históricas e linguísticas. Mattos (2001, p. 65) nos esclarece:

Partindo-se da ideia de que a língua é diálogo, mediação, forma de ação ou interação que transforma, que constitui identidades, lugar de poder e de tensão que se caracteriza por uma briga permanente entre o formal e o histórico, o social, o ideológico, conclui-se que todos os textos produzidos caracterizam-se, de certa forma, pela argumentatividade. Como indivíduo dotado de razão e vontade, ao mesmo tempo em que é determinado sócio-historicamente, o ser humano, com certa frequência, avalia, julga, critica, forma juízo de valor, tenta influir sobre os seus interlocutores.

A língua é, dessa forma, um instrumento de representação do mundo que se tem, que se entende, que se propaga, que se quer e que pode vir a ser eficaz para que toda a transformação sonhada e desejada possa ser realizada. É por meio da língua que o sujeito se mostra para o mundo. Para nós, isso se dá sempre por meio dos textos.

4 - Os sentidos das palavras - Toda e qualquer experiência pessoal pode ser expressa pelas palavras. Elas nos possibilitam a interação e a argumentação, o agir sobre o outro, revelando situações comunicativas de todas as espécies (desde a conversa de bar até um debate entre presidenciáveis). A palavra descontextualizada só nos remete a um símbolo dotado de significação limitada. É na interação que os sentidos se configuram por meio de 
formas linguísticas e que podemos perceber, para além dos sentidos e das significações, as valorações subjetivas dadas pelos usuários da língua. No texto escrito, isso se dá por meio das escolhas lexicais reveladoras das intenções do sujeito. Nessas intenções, identificamos que tipo de mensagem está sendo veiculada e compreendemos o estilo de cada aluno. Os PCNS nos revelam:

O significado [...] constrói-se pelo esforço da interpretação do leitor, a partir não só do que está escrito, mas do conhecimento que traz para o texto. É necessário que o professor tente compreender o que há por trás dos diferentes sentidos atribuídos pelos alunos aos textos; às vezes é porque o autor intencionalmente "jogou com as palavras" para provocar interpretações múltiplas; às vezes é porque o texto é difícil ou confuso; às vezes é porque o leitor tem pouco conhecimento sobre o assunto tratado e, a despeito do seu esforço, compreende mal (BRASIL, 1998, p. 57).

Os professores de língua e de linguagem precisam compreender que é na fala, na audição, na escrita, na leitura, nas análises, nos diálogos, nas respostas, nas reflexões, na permanente convivência com o outro que nos realizamos como sujeitos, criamos nossas expectativas e exigimos do outro a reflexão, a crítica, a invenção, a eleição, decisão, organização, ação, práticas que nos formam moralmente e intelectualmente (FREIRE, 1982).

5 - Os domínios da linguagem - De forma alguma, as estruturas gramaticais devem ser esquecidas nas nossas práticas de sala de aula. Assim como a língua é pulsante, latente e dinâmica, também a gramática se apresenta, a todo instante, em construção. A ideia de uma gramática "inflexível, rígida" é altamente equivocada. Para Antunes (2017, p. 152):

É preciso ir além, é preciso saber muito mais coisas além de gramática... É preciso conhecer o léxico de uma língua e suas possibilidades de se renovar; é preciso conhecer os muitos recursos - sintáticos e semânticos - para produzir, com as palavras, diferentes efeitos de sentido; é preciso o cálculo do que deve ser explicitado e do que pode ficar implícito; é preciso conhecer as propriedades que fazem do conjunto de palavras um texto; é preciso conhecer os modelos textuais, no que diz respeito a seus tipos e gêneros; é preciso conhecer as estratégias de adequar o 
texto a diferentes propósitos comunicativos, a seus contextos de uso, a seus interlocutores; é preciso ir além da frase; é preciso ir além da morfologia, para chegar à sintaxe (às regularidades de combinação das palavras), à semântica (aos recursos de produção e apreensão dos sentidos), à pragmática (às implicações dos usos em diferentes situações).

De fato, já se foi o tempo em que tínhamos que obedecer cegamente aos princípios gramaticais. Os tempos são outros. Precisamos ensinar os nossos alunos a questionarem determinadas "fórmulas sintáticas" e "regras morfológicas", a fim de trazê-los para a reflexão, o pensamento crítico e, dessa forma, entender que, apesar de toda a convenção gramatical, a gramática é flexível. No plano da escrita, temos a clareza de que há um conjunto de convenções próprias e específicas, que nos servem para que sejamos lidos e compreendidos. As questões envolvidas no processo de construção dos textos em sala de aula estão relacionadas ao entendimento de que aprender a ler/escrever significa aprender nomenclaturas, regras, combinações, conceitos, mas não é por meio da memorização dessas questões que os alunos aprenderão sua língua. É preciso que haja o uso de uma língua reflexiva e analítica no plano individual, coletivo e interativo.

6 - A oralidade - Temos como regra básica da conversação a ordenação e a sequenciação de cada falante, para que todos possam se comunicar. As interrupções só se dão mediante a "permissão" de cada interlocutor, possibilitando o fluxo normal da interação oral. Podemos dizer que o texto oral é uma atividade de coprodução discursiva importante para levar o aluno a refletir sobre pontos a serem narrados, descritos e/ou argumentados, de acordo com a situação textual na escola ou na vida cotidiana. Para Franco (1997, p. 18-19):

A linguagem oral ganha características sociais: não é qualquer ruído que serve, mas são as palavras, articuladas e interligadas, que permitirão as trocas, a conversação. Portanto, falar só não basta, é necessário ir além. [...] Neste processo de conversação, há de se discutir a questão do ouvir. Ouvir exige critérios. Ouvir significa acompanhar o discurso do(s) outro(s), entender o que eles(s) dizem e/ou propõe(m), para interferir no momento certo, concordar, discordar, argumentar, provocar. 
$\mathrm{Na}$ sala de aula, é importante que o professor proporcione a ambientação interativa, antes de qualquer produção de textos, pois a troca de informações, a relevância dos argumentos e a seleção temática acontecem nesse momento. $\mathrm{Na}$ verdade, quando essa prática acontece, diminuímos significativamente a possibilidade de o aluno dizer "Ih... Não sei o que escrever" ou "Pra que estou escrevendo isso?", frases corriqueiras entre eles, nas aulas de Língua Portuguesa.

De certa forma, todos esses aspectos elencados nos remetem para outras questões exigidas nas condições de produção de textos em sala de aula. São elas:

a) Que o aluno possua conhecimentos de mundo, linguístico e intelectual necessários para escrever aquilo que se pede - CONHECIMENTO;

b) Que o aluno encontre sentido para aquilo que vai escrever - SENTIDOS;

c) Queo aluno,de fato, tenha clara em sua mente aideia de que, quando escrevemos, escrevemos para alguém - INTERLOCUÇÃO;

d) Que o aluno assuma sua responsabilidade com aquilo que escreve - COMPROMISSO;

e) Que o aluno apresente as estratégias de abordagem e organização textual - FORMA DO TEXTO;

A partir deste ponto, é importante refletirmos um pouco mais sobre questões que estão diretamente associadas ao conhecimento, aos sentidos, à interlocução, ao compromisso e à forma do texto, que foram destacadas como palavras-chave anteriormente. No que tange ao CONHECIMENTO, tratamos de observar a oralidade, a escrita, a leitura e a gramática (ANTUNES, 2003).Para cada "parte" desse conhecimento, apresentamos algumas questões.

No tocante à oralidade, ainda presenciamos uma ausência significativa de atividades de fala na produção de textos. Não é "falar por falar", mas educar a fala para fins comunicativos diversos. Muitos professores sequer permitem que seus alunos opinem e contribuam nas discussões em sala. Discussões? Ainda há professores acreditando que a sala de aula é o 
ambiente apenas do professor. Ledo engano. Dolz e Schneuwly (2004, p. 125) apontam que:

Embora a linguagem oral esteja bastante presente nas salas de aula (nas rotinas cotidianas, na leitura de instruções, na correção de exercícios etc.), afirma-se frequentemente que ela não é ensinada, a não ser incidentalmente, durante atividades diversas e pouco controladas. Assim como denunciam didatas, sociólogos, linguistas e formadores de professores (Wirthner, Martin e Perrenoud 1991; De Pietro e Wirthner 1996), o ensino escolar da língua oral e de seu uso ocupa atualmente lugar limitado.

Ainda há uma visão de que a fala é permissiva, desprendida das regras gramaticais. Não entendamos aqui as regras gramaticais como aprisionamento, mas como diretrizes, para que a comunicação e a interação sejam plenamente estabelecidas.

Muitas práticas linguísticas em sala de aula ainda se conservam na informalidade, em detrimento das possibilidades de um uso didático também mais formal. $\mathrm{Na}$ verdade, todos os registros de oralidade podem e devem ser explorados, para fins comunicativos. Os alunos também precisam ter a consciência de que há um diálogo entre a fala e a escrita. São modalidades distintas com características próprias, mas sem dúvida apresentam seus muitos pontos de contato.

Há a necessidade de se instituir a abordagem dos gêneros orais, a fim de mostrar aos alunos as possibilidades de escolhas lexicais, as estratégias semânticas, as organizações sintáticas, os esquemas pragmáticos, enfim, todas as possibilidades de construção dos textos orais.

Quanto à escrita, ainda se ignoram as potencialidades de representações linguísticas em muitas escolas. É preciso dar ao aluno as oportunidades de se representar, de se colocar como sujeito aprendiz e escritor. $O$ ideal seria que nós, professores, exercêssemos nosso papel de condutores da escrita, ou seja, de mediadores que se sentam com o aluno, oportunizando-lhe "arquitetar" o texto, formular hipóteses e elaborar estruturas argumentativas do texto. 
Será que quem ainda apresenta problemas ortográficos não sabe escrever? Essa é uma visão muito limitada do que se quer como aluno-produtor de textos. Um texto repleto de regras gramaticais bem aplicadas e próximo à perfeição ortográfica não garante o seu teor argumentativo. Esse tipo de situação só demonstra uma competência gramatical muitas vezes dissociada da competência textual.

Parece que falamos o óbvio, mas ainda é necessário alertar os professores quanto ao uso de exercícios improdutivos, que pouco ajudam na problematização das questões linguísticas e nas suas resoluções. O resultado é alarmante: alunos que saem da escola sem a noção mínima do que é um texto, porque passaram a vida escolar "fragmentada", ou seja, analisando e construindo fragmentos de textos, histórias "sem pé, nem cabeça". Como $\operatorname{diz}$ Antunes (2003, p. 26):

Parece incrível, mas é na escola que as pessoas 'exercitam' a linguagem ao contrário, ou seja, a linguagem que não diz nada. Nessa linguagem vazia, os princípios básicos são violados, porque o que se diz é reduzido a uma sequência de frases desligadas umas das outras, sem qualquer perspectiva de ordem ou de progressão e sem responder a qualquer tipo particular de contexto social.

É o típico caso do ensino de língua descontextualizado.

Ainda temos o caso de práticas de escrita sem qualquer tipo de planejamento e revisão. Em muitas situações, essas produções revelam apenas o exercício da "tarefa cumprida", sem qualquer objetividade de ensino, ampliação do repertório vocabular, lexical, atenção aos critérios sintáticos de organização do pensamento para a correspondência semântica. No fundo, é o caso da tarefa de escrever sem sentido.

Chama-nos atenção o fato de percebermos, quanto às atividades de leitura, em inúmeras situações de aula, que quase sempre não há interação verbal, não se "lê para o outro". É preciso criar a consciência de que a leitura em voz alta é necessária para a percepção da entoação, do ritmo, da cadência, elementos significativos na produção de sentidos de cada palavra presente na produção escrita. 
Quantas vezes o aluno lê só porque o professor exigiu sua participação? A motivação para a leitura precisa ser propagada, disseminada, cultivada, para que o aluno perceba que é por meio dela que acontece a socialização, a partilha do conhecimento apreendido.

Desde quando podemos entender que leitura é treino? Ideias como essa são disseminadas para tentar "atrair" o aluno. No fundo, isso só o afasta ainda mais de toda e qualquer prática de leitura eficaz e producente. $\mathrm{O}$ que o professor de Língua Portuguesa precisa entender é que o ato de leitura deve ser cultivado por meio de textos interessantes para o aluno, conteúdos que despertem a curiosidade dele, livros que consigam atraí-lo pela qualidade da escrita ou pelo assunto abordado. A partir daí, podemos tentar o início de uma formação de leitura. É claro que essa é apenas uma ideia. Outras também oportunas podem surgir, de acordo com cada contexto de sala de aula.

Para que consigamos bons resultados, também podemos mostrar as variadas funções sociais da leitura. Antunes (2003, p. 28) nos diz que "muitas vezes, o que se lê na escola não coincide com o que se lê fora dela". Dois mundos paralelos são apresentados para o aluno e ele não consegue entender que as leituras se misturam, completam-se num continuum linguístico-expressivo. Torna-se clara a necessidade de se mostrar que a escola faz parte do seu mundo e que o mundo faz parte da sua escola.

Para aramática, sempre foi dado o lugar de destaque, de "imperatriz" da aula de Língua Portuguesa. Isso ocorre porque sempre se cultivou uma tradição falaciosa de que "quem sabe gramática escreve bem”. A descontextualização da gramática felizmente tem sido eliminada da escola, mas ainda há muito a se fazer. O trabalho é árduo e os professores, as capacitações, as atividades de extensão das universidades têm se dedicado a transformar essa realidade.

Assim como na escrita, o ensino de gramática por muito tempo perdurou, fincado em questões sem importância para o desenvolvimento da competência comunicativa dos falantes. É o caso da exploração das regras, das excentricidades presentes nas gramáticas escolares. Quanto tempo se perde em determinados conteúdos... E mais: o professor perde a oportunidade de estabelecer as relações daquele conteúdo com a aplicabilidade 
textual, mostrando para os alunos o porquê daquela ocorrência $\mathrm{X}$ na situação Y. Não podemos desconsiderar que o aluno busca sentido para aquilo que se está ensinando/aprendendo, o tempo todo. O "fazer sentido" talvez seja a "alma do negócio".

Uma tarefa interessante pode (e deve) ser o ensino da gramática apoiado nos textos que circulam nos variados meios de comunicação, nas redes sociais, nos textos literários, apresentando as manifestações textuais de maneira funcional. Apresentar os fatos gramaticais por meio desses textos traz a vivacidade da língua e de suas operações (meta)linguísticas. É uma possibilidade de se reconhecer uma língua viva, como se falará mais detalhadamente em outro capítulo desta obra.

Agora é necessário falarmos de SENTIDOS. Sempre que pensamos nessa questão, refletimos sobre as estratégias de elaboração dos textos, no que diz respeito ao "jeito de dizer o que se tem para dizer e o que se quer dizer”. Tomaremos por base os estudos de Koch (2001) para defendermos nossa tomada de posição diante do que acreditamos serem elementos propícios à construção dos sentidos no texto.

A organização da informação textual, no caso, a semântica, é apontada por Koch (2001) em dois grandes blocos: o dado e o novo, interferindo substancialmente na construção do sentido. A informação dada pode ser entendida como aquela que está localizada na consciência do interlocutor e que serve como base para que a informação nova seja apresentada e entendida. Nesse caso, os elementos responsáveis por construírem textualmente essas informações são representados por remissões ou referências textuais, formando as cadeias coesivas, importantes para a organização textual, consequentemente, para a produção de sentido.

Texto só é texto, se fizer sentido. Vale lembrar que, para Koch (2001, p. 25), "o sentido não está no texto, mas se constrói a partir dele, no curso de uma interação". Nesse caso, operam-se várias estratégias cognitivas e interacionais, para que as palavras façam sentido e que as relações entre explícitos e implícitos sejam harmoniosamente combinadas. É interessante ressaltar também que não há "o" sentido do texto, mas “os" sentidos construídos para 
ele, e o que se quer do aluno é que ele seja capaz de construir, perceber e identificar pelo menos "um" sentido.

De acordo com as ideias de Van Dijk \& Kintsch (1983), Koch (2001, p. 29) discorre sobre as estratégias cognitivas, afirmando que "o processamento cognitivo de um texto consiste de diferentes estratégias processuais, entendendo-se estratégia como uma 'instrução global para cada escolha a ser feita no curso da ação"'. Entendamos essas estratégias como as possibilidades de construção da estrutura textual e os sentidos do texto inteiro ou de seus fragmentos. Koch (2001, p. 29) acrescenta que:

Elas fazem parte do nosso conhecimento geral, representando o conhecimento procedural que possuímos sobre compreensão do discurso. Falar em processamento estratégico significa dizer que os usuários da língua realizam simultaneamente em vários níveis passos interpretativos finalisticamente orientados, efetivos, eficientes, flexíveis, tentativos e extremamente rápidos (2001, p. 29).

Sendo assim, é possível ao aluno realizar esse processamento de forma processual, em várias etapas, construindo uma rede de significações daquilo que se quer significar, dizer. À medida que ele, aluno, inicia sua "engenharia" textual, dá-se início ao encadeamento das informações, para que, na sua completude, totalidade, resulte naquilo que se quer como texto.

Ao analisarmos a questão da INTERLOCUÇÃO, pensamos no aluno, no processo de interação, nos meios de expressão utilizados para se comunicar, no acesso às informações, nas expressões de sentidos e nas defesas dos pontos de vista, no compartilhamento e na construção das visões de mundo, no ato de produzir cultura. É pela língua que ele realiza todas essas ações sociais, por meio das relações interpessoais. $\mathrm{Na}$ prática, o que constatamos é a dificuldade de os alunos organizarem as informações no plano textual, pelo desconhecimento dos esquemas textuais que realizam os diversos tipos de textos. A escola, na verdade, deixa de proporcionar essas ações, quando não ensina o aluno a refazer, a reescrever, a reorganizar, a revisar os textos. Todas as atividades de "re-" são esquecidas, abandonadas, 
descartadas pelo professor, consideradas menores. Esse é um equívoco imenso, uma grande perda para o processo de construção de textos.

É possível fazer que os alunos participem desse processo, à medida que utilizamos a cooperação como elemento fundamental da interlocução. É o dizer para o outro, é colaborar com o que o outro quer dizer, é a formação da consciência do que se quer dizer, porque quem escreve escreve para alguém. Nesse sentido, Mattos (2001, p. 65) nos diz que:

Partindo-se da ideia de que a língua é diálogo, mediação, forma de ação ou interação que transforma, que constitui identidades, lugar de poder e de tensão que se caracteriza por uma briga permanente entre o formal e o histórico, o social, o ideológico, conclui-se que todos os textos produzidos caracterizam-se, de certa forma, pela argumentatividade.

Dessas palavras, compreendemos que os alunos frequentemente têm a chance de serem preparados para julgar, avaliar, criticar, valorar, opinar, interferir, influindo sobre o outro, exercendo seu papel de verdadeiro interlocutor do texto. É dada ao aluno a oportunidade de ser avaliador do texto do outro e do seu próprio texto. $\mathrm{Na}$ realidade, todo aluno deve ser o primeiro avaliador da sua produção escrita. Perguntamos: quando isso acontece na escola? A resposta todos já sabemos. Precisamos refletir também nessa questão.

O COMPROMISSO é uma questão pertinente ao ato de o aluno assumir a responsabilidade com aquilo que escreve, ou seja, é a tomada de posicionamento social como cidadão linguístico. O "casamento" do exercício da reflexão crítica com a conscientização linguística para a apreciação dos sentidos pode levar o aluno ao "sucesso da vida feliz" com as suas produções escritas. Cabe ao professor proporcionar aos estudantes momentos de reflexão crítica, com análise de textos variados (literários, canções, charges, entrevistas etc) com vistas à instrumentalização de todo o seu aparato linguístico-textual para a organização de textos. Na verdade, é lendo de tudo que se informa sobre tudo, e só se pode dar o que se tem. No caso, as aulas devem ter atividades de leitura e reflexão sobre tudo o 
que nos cerca e nos faz sujeitos sociais, promovendo a capacitação crítica de cada aprendiz. Com isso, os professores têm a oportunidade de mostrar que escrever é se comprometer com o mundo, com as pessoas, e que a escrita é, sim, um ato responsável. Sobre o ato de leitura, Brito (2001, p. 49) nos chama à reflexão:

Mais do que a simples exigência da reprodução do significado literal, a escola deve orientar os alunos no sentido de que, através da reconstrução da intenção argumentativa, é possível a tomada de uma postura crítica frente ao texto, postura esta que se faz essencial para a compreensão. Faz-se necessário, pois, que os professores não só tenham acesso às pesquisas na área de leitura, mas também (e principalmente) procurem efetuar um trabalho empírico em sala de aula, a fim de que possam dotar seus alunos de um senso crítico mais apurado, no sentido de que, diante de um texto, possam ir além da simples extração do significado literal. Obviamente, cabe às escolas brasileiras abraçarem uma "nova linha pedagógica", possibilitando a todos os alunos (e não só àqueles que são considerados 'bons' leitores devido a 'virtudes inatas') a descoberta de caminhos adequados para a realização de uma leitura dialógica, questionadora e crítica. Caso contrário, estaremos eternamente correndo o risco de formarmos indivíduos amorfos, que acatam pacificamente tudo o que está escrito nos textos e, o que é pior, que não fazem valer o seu próprio dizer.

Todas as palavras do texto transcrito só corroboram o nosso pensamento sobre o ato de leitura, e as estendemos ao processo de escrita. Vale ressaltar que as reflexões da autora fazem parte de uma década anterior à que vivemos, mas que, ao serem contextualizadas, fazem-se atuais, diante do cenário de ensino vivenciado por nós. Da mesma forma que precisa refletir sobre o que lê, o aluno também precisa estar apto a refletir sobre o que escreve, e essa condução/mediação precisa ser executada pelo professor. Esperamos que a sala de aula seja o ambiente propício e profícuo para essas tarefas tão representativas e significativas no processo de construção de textos. 
De fato, se o ato de pensar o mundo fosse a verdadeira ação da escola, ela proporcionaria ao aluno a possibilidade de se tornar um indivíduo reflexivo e compromissado com sua sociedade, capaz de entender-se a si mesmo e aos outros e de interagir com a sua história de mundo, de vida, além de realizar plenamente as operações comunicativas (falar, ouvir, escrever e olhar), atividades essenciais no processo de integração social.

Por fim, ao pensarmos a FORMA DO TEXTO, buscamos a reflexão e o entendimento das estratégias de organização textual. Se tomarmos por base o que Antunes (2003, p. 47) nos diz, encontraremos um caminho fértil para que o aluno possa "pensar" em como construir seus textos: "A escrita, na diversidade de seus usos, cumpre funções comunicativas socialmente específicas e relevantes". É fato que a escrita tem por meta o cumprimento de variadas funções comunicativas, sejam elas quais forem, e há sempre um propósito funcional. Sendo assim, o aluno deve ter em mente qual a função básica de seu texto (julgar, opinar, informar, avisar, instruir, argumentar, descrever, narrar) e, a partir daí, se servir da estrutura textual pertinente ao seu objetivo. Nada cai do céu. O professor, mais uma vez, faz-se presente e de extrema importância para demonstrar todas (ou quase todas) as possibilidades estruturais para o aprendiz. Ainda é Antunes (2003, p. 48) que nos diz: "A escrita varia, na sua forma, em decorrência das diferenças de função que se propõe cumprir e, consequentemente, em decorrência dos diferentes gêneros em que se realiza”. A produção de textos escritos recebe formas diferentes, por parte do aluno, de acordo com a pretensão dele e as funções destinadas a sua escrita.

Os gêneros textuais assumem papel relevante nessa questão da organização textual, quando analisamos a forma e a função do texto, isto é, para cada produção escrita um gênero e, para cada gênero, uma função. Nesse sentido, é importante apresentar aos alunos a natureza complexa das atividades linguísticas: as diferenças, a mutabilidade, as multiformas, os contextos, os valores semânticos e pragmáticos, sem nos esquecermos de que ainda há a prototipicidade de cada uma das realizações linguísticas. Em consonância com esse direcionamento processual, trazemos à luz as palavras de Antunes (2003, p. 50): 
Em síntese, uma escrita uniforme, sem variações de superestrutura, de organização, de sequência de suas partes, corresponde a uma escrita sem função, artificial, mecânica, inexpressiva, descontextualizada, convertida em puro treino e exercício escolar, que não estimula, nem fascina ninguém, pois se esgota nos reduzidos limites das próprias paredes escolares.

Além disso, o aluno precisa compreender que a escrita possui variadas etapas de execução, dentre elas, o planejamento e a revisão. Na revisão, cabe ao aluno avaliar se os objetivos do seu texto foram cumpridos, se o seu compromisso social, de fato, foi assumido e se todas as operações linguístico-textuais utilizadas foram eficazes na abordagem e na organização textual.

Cada texto apresenta diferenças formais decorrentes das funções que eles assumem. Cada situação interativa, por sua vez, proporcionará a atribuição de sentido ao texto, por conta das diferentes formas de se escrever. Isso demonstra a diversidade textual tão desejada e, ainda, mal explorada por alguns professores. As boas intenções existem, mas não podemos nos resumir a elas. Se seguirmos as orientações destacadas, se pensarmos em uma sala de aula "mais leitora", se expusermos nossos alunos ao mundo da escrita, "de ponta a cabeça", se fizermos o que precisa ser feito, talvez não soframos tanto e entendamos que o processo de construção de textos é contínuo, pois, afinal: quem sabe escrever? 


\section{Exercícios}

1 De que maneira podemos entender a "tríade" nomeada por nós e proposta por Antunes (2007)?

2 Elabore, em tópicos resumitivos, suas considerações sobre os aspectos para o trabalho da linguagem associados às condições de produções de textos.

3 Como podemos entender o trabalho da análise linguística como auxiliador no processo de construção de textos?

4 Escolha um aspecto (CONHECIMENTO, SENTIDO, INTERLOCUÇÃO, COMPROMISSO, FORMA DO TEXTO) e explique de que maneira ele pode contribuir ou já contribui para as suas aulas.

\section{Resumo}

Este capítulo teve como objetivo apresentar algumas possibilidades de trabalho nos processos de construção de textos dos alunos. Tratamos de observar as condições reais de produção e o que envolve a prática do professor nas aulas de Língua Portuguesa. Tivemos a preocupação de refletir sobre o que se envolve no aprendizado linguístico que permite ao aluno construir suas histórias e enredos. Procuramos demonstrar a construção e a reconstrução do processo verbal, a fim de apresentar de que modo o texto é uma rede de significações.

Lembramos que as práticas de análise linguística perfazem a construção de um conhecimento textual, extrapolador das palavras, possibilitando o desenvolvimento linguístico do aluno, capacitando-o linguisticamente, lexicalmente, semanticamente e pragmaticamente, a cada dia, na sala de aula e em todas as situações comunicativas. Destacamos a importância da sala de aula como ambiente propício para o aprendizado linguístico-textual. É nela que tudo acontece... Ou deveria acontecer. 
Elencamos algumas questões que consideramos pertinentes às condições de produção de textos em sala de aula e ressaltamos que cada texto apresenta diferenças formais decorrentes das funções que eles tomam como matéria. Demonstramos que as situações interativas são responsáveis pela atribuição de sentidos ao texto por conta das diferentes formas de se escrever. Também alertamos sobre a importância da diversidade textual tão desejada e, ainda, pouco praticada pelos alunos em sala de aula. Por fim, propusemos algumas reflexões para que tenhamos aulas de Língua Portuguesa mais produtivas e mais envolvidas nos processos de escrita, com o propósito de que, de fato, os processos de construção de textos estejam claros para os professores e para os alunos.

\section{Referências}

ANTUNES, Irandé. Aula de Português: Encontro \& Interação. São Paulo: Parábola Editorial, 2003.

ANTUNES, Irandé. Lingua, texto e ensino: Outra escola possível. São Paulo: Parábola Editorial, 2009.

ANTUNES, Irandé. Textualidade: noções básicas e implicaçôes pedagógicas. São Paulo: Parábola Editorial, 2017.

BRASIL. Secretaria de Ensino Fundamental. Parâmetros Curriculares Nacionais de Lingua Portuguesa. $3^{\circ}$ e $4^{\circ}$ ciclos. Brasília: MEC, 1998.

BRITO, Eliana Vianna. Estratégias de leitura: a formação do leitor no ensino fundamental. In: BRITO, Eliana Vianna (Org.). PCNs de Língua Portuguesa: a prática em sala de aula. São Paulo: Arte \& Ciência, 2001.

DOLZ, Joaquim; NOVERRAZ, Michele; SCHNEUWLY, Bernard. Sequências didáticas para o oral e a escrita: apresentação de um procedimento. In: DOLZ, Joaquim; SCHNEUWLY, Bernard e colaboradores. Gêneros orais e escritos na escola. Trad. e Org. de Roxane Rojo e Glaís Sales Cordeiro. Campinas, SP: Mercado das Letras, 2004.

FRANCO, Ângela. Metodologia de ensino: Lingua Portuguesa. Belo Horizonte: Ed. Lê: Fundação Helena Antipoff, 1997.

FREIRE, Paulo. A importância do ato de ler. São Paulo: Cortez, 1982.

KOCH, Ingedore G. V. O texto e a construção dos sentidos. São Paulo: Contexto, 2001. 
KOCH, Ingedore G. V . As tramas do texto. 2. ed. São Paulo: Cortez, 2014.

MATTOS, José Miguel. O texto escrito no contexto escolar. In: BRITO, Eliana Vianna (Org.). PCNs de Lingua Portuguesa: a prática em sala de aula. São Paulo: Arte \& Ciência, 2001.

VAN DIJK, Teun Adrianus; KINTSCH, Walter. Strategies of discourse comprehension. New York: Academic Press, 1983. 



\section{ANÁLISE LINGUÍSTICA E SEMIÓTICA}

Monclar Guimarães Lopes (UFF)

\section{Objetivos}

Ao final deste capítulo, você deve ser capaz de compreender...

- por que defendemos uma gramática do texto;

- como promover atividades de análise linguística pautadas em textos;

- algumas estratégias de significação em semioses não verbais.

Não existe ação de linguagem - ação necessariamente textual - que dispense o concurso da gramática, que dispense o concurso do léxico e de fatores contextuais que sejam relevantes para o êxito da comunicação.

(ANTUNES, 2014, p. 31)

\section{Introdução}

No primeiro capítulo deste livro, tendo como base os documentos oficiais, sobretudo os PCN (BRASIL, 1998) e a BNCC (BRASIL, 2018), esclarecemos que o principal objetivo do ensino de Língua Portuguesa é o desenvolvimento da competência discursiva. Sendo assim, deve o aluno, ao longo de toda a Educação Básica, tornar-se proficiente na leitura e produção de textos de variados gêneros. Sob esse ponto de vista, a gramática assume um papel secundário, sendo considerada como um instrumento necessário para a expressão linguística nas mais variadas situações de interação.

Vale ressaltar que, embora não neguemos a instrumentalidade da gramática, vemo-la de uma perspectiva diferente: a gramática assume uma perspectiva textual e discursiva, isto é, dissociamos a ideia de que a gramática se restringe aos níveis fonológico, morfológico, sintático e semântico da língua. De fato, além desses níveis, a gramática apresenta propriedades 
pragmáticas e discursivo-funcionais, que dão conta de unidades discursivas maiores do que o período, como o texto, por exemplo.

Paralelamente, atendendo às orientações da versão mais recente da BNCC (BRASIL, 2018), propomos, ao lado da análise linguística, uma abordagem semiótica. Com base nessas premissas, nosso objetivo, neste capítulo, é o de apresentar algumas reflexões, bem como algumas categorias que podem ser facilmente aplicadas para a compreensão e interpretação de textos multissemióticos. Reconhecemos, porém, que as análises propostas representam apenas a ponta do iceberg, sendo necessário, aos interessados, um posterior estudo mais aprofundado e sistemático da semiótica do discurso.

Feitas essas considerações iniciais, tratemos agora da organização deste capítulo, dividido em quatro partes. Em Da gramática da frase à gramática do texto, buscamos explicar as implicações do estudo gramatical que tem o texto como unidade de análise. Dividida em três subtópicos, essa seção busca: a) defender por que a gramática deve ser vista como plural; b) mostrar algumas das relações gramaticais próprias do nível transfrásico; c) tratar da variação e da variabilidade linguísticas e relacionar esses conceitos com o conhecimento que temos da gramática. Em Para além da análise linguística: o estudo das diferentes semioses, buscamos apresentar algumas reflexões e categorias para a análise semiótica. Também dividida em três subtópicos, essa seção busca: a) apresentar a base fenomenológica da semiótica; b) diferenciar plano de conteúdo de plano de expressão; c) descrever o nível fundamental da semiótica do discurso e apresentar o papel das isotopias na reiteração de temas e figuras. Por fim, apresentamos um exercício e um resumo do capítulo, além das referências bibliográficas.

\section{Da gramática da frase à gramática do texto}

Durante muito tempo, acreditou-se que a escrita fosse uma representação da fala. Sob esse ponto de vista, para ser um escritor proficiente, bastava: a) ser alfabetizado, isto é, dominar a tecnologia da escrita; b) dominar a gramática teórica e a normativa (sendo a primeira pré-requisito para 
a segunda) para se adequar às normas do uso linguístico no que tange à concordância, regência, colocação pronominal, ortografia, acentuação, pontuação, seleção vocabular, entre outros aspectos. Sendo assim, justificava-se uma metodologia de ensino centrada na transmissão da metalinguagem e das normas de uso, já que estas últimas eram tidas como invariáveis e inflexíveis, sob a crença de que uma única regra valia para todas as situações de produção do discurso. Quando se dizia a uma criança que ela não deveria usar "ter" no sentido de "existir", por exemplo, considerava-se que as formas existenciais de "ter" eram erradas e, por isso, deveriam ser evitadas em quaisquer contextos, inclusive nos gêneros da modalidade oral. No entanto, hoje se reconhece que essas "regras" são flexíveis e dependem tanto do gênero quanto da modalidade de texto (se oral ou escrita).

A insuficiência desse tipo de abordagem se dá não somente pela rigidez das "regras" de uso, como também pelo escopo de análise, que se encerra no período. Afinal, escrever períodos gramaticalmente adequados à norma culta não é condição suficiente para a produção de bons textos. Inclusive, como sabemos, a justaposição de vários períodos gramaticalmente adequados nem sempre resulta em um texto. Paralelamente, as relações gramaticais podem se estabelecer entre porções transfrásicas, além de serem suscetíveis à variação e à variabilidade linguísticas ${ }^{1}$. Vejamos alguns exemplos:

(1) João vai à padaria. A padaria é feita de tijolos. Os tijolos são caríssimos. Também os mísseis são caríssimos. Os mísseis são lançados no espaço. Segundo a Teoria da Relatividade o espaço é curvo. A geometria rimaniana dá conta desse fenômeno. (MARCUSCHI, 1983, p. 31)

\section{(2) A professora assustada}

Quando eu tinha, 4 anos eu e os meus amigos Marcella e Sávio em 2004, aqui na escola nos estávamos voltando do recreio do turno da tarde, nós estudávamos no primeiro pavimento, e o segundo pavimento,

\footnotetext{
${ }^{1}$ Assumimos, aqui, uma diferença entre variação e variabilidade linguísticas. No primeiro caso, temos duas formas distintas com função equivalente para um dado contexto; no segundo, uma mesma forma apresenta funções distintas em contextos diferentes.
} 
havia um coelhinha a exposição, aproveitamos a subida do recreio e fomos ver o coelhinho, e os nossos colegas e a professora nem viu.

Foi aí que quando chegamos lá vimos o tal do coelhinho, mas o irmão da Marcella Matheus estudava no segundo pavimento e ele nos perguntou o que vocês estão fazendo aqui, e nós respondemos que a professora tinha deixado, enquanto isso a professora nervosa pos nem um sinal da gente e ela chegou a ligar para os nossos pais. Mas depois chegamos lá e ficamos de castigo a frente da lousa e a minha amiga Marcella fez xixi na sala (GRAMA, 2017, p. 16).

(3) Cara S.

O corpus já seguiu há mais de uma semana.

Espero que chegue tudo bem.

A F. assinou o protocolo, mas não confirmei se ela lho tinha reenviado. Vou perguntar-lhe.

Beijinhos, (VIEIRA, 2009, 3p. 61)

(4) Essa semana foi bem corrida pra mim. A novidade é que eu ganhei uma vaga num workshop de computação gráfica e artes digitais, que vai rolar em outubro, e depois dele eu vou saber se fico ou não no curso profissionalizante. Se ficar vou ter menos tempo do que já tenho pro blog, o que é uma pena, mas poderei fazer várias melhorias por aqui, além de aprender uma coisa que gosto muito. Então, que tudo dê certo! Enfim, estava sem imaginação pra fazer posts, então resolvi responder esse meme que ganhei da Amanda, dona do blog Ohayo (...) (AZEVEDO, 2018, p. 109).

Em (1), há um exemplo de não-texto, na medida em que a sequência de períodos negligencia uma condição sine qua non para a textualidade: a coerência. Isto é, um texto não pode ser caracterizado como uma sequência de frases mal relacionadas, que não promovem a progressão temática. Em (2), um relato de aluno de $8^{\circ}$ ano, há diversos desvios, dentre os quais se destacou o emprego do conector mas na penúltima linha: trata-se de cone- 
xão interfrástica inadequada, uma vez que não há, nessa ocorrência, relação de oposição. Em (3), a forma lho representa, ao mesmo tempo, a função de OD e OI. Trata-se, aqui, de uma forma culta opcional e, portanto, variável. No Português Brasileiro, por exemplo, o mais provável é que se empregasse a forma "lhe" na função de objeto indireto, deixando-se o OD elíptico. Por fim, em (4), enfim é empregado na função de marcador discursivo, muito embora possa apresentar outras funções na língua, como advérbio de tempo e advérbio modalizador, por exemplo. Ou seja, é um item que apresenta variabilidade, cuja função dependente do contexto de uso.

A partir dessas análises, fazemos, neste capítulo, três considerações importantes sobre o tratamento da gramática: 1) a gramática é plural, na medida em que a seleção de um determinado recurso gramatical está associada à intencionalidade do falante, ao gênero e à modalidade de texto; 2) há relações gramaticais no nível transfrásico, o que justifica um estudo de gramática que inclua unidades maiores de análise que o período; 3) a variação linguística também recobre os usos cultos da linguagem, uma vez que a norma culta também está subordinada aos gêneros e às modalidades textuais, bem como às escolhas dos falantes. Tais pontos são explorados mais detidamente a seguir.

\section{A gramática plural}

Refutamos a ideia de que a gramática represente um conjunto de regras abstratas, replicadas pelos falantes independentemente do contexto de uso. Defendemos a existência de uma relação direta entre gramática e texto, de modo que a descrição linguística se torna mais adequada quando a investigação leva em consideração as diferentes situações de produção do discurso. Sob esse ponto de vista, pesam fatores pragmáticos e discursivo-funcionais, como a intencionalidade do falante, os gêneros e as modalidades textuais.

Como ilustração dessas três instâncias que acabamos de citar, analisemos os seguintes casos: a) a relação entre a ordenação dos termos da oração e intencionalidade do sujeito; b) a função dos substantivos abstra- 
tos para a progressão temática em textos argumentativos; c) o papel dos marcadores discursivos no planejamento e na manutenção do turno dos textos orais.

No que tange à ordenação dos termos da oração, tomemos as seguintes frases: a) Ontem eu comprei este livro; b) Eu comprei este livro ontem. As duas, de fato, são semanticamente equivalentes e possuem o mesmo valor de verdade, na medida em que a ordenação não implica um novo sentido nem um novo escopo para o advérbio "ontem", que continua fazendo referência ao verbo "comprar". No entanto, potencialmente, elas são pragmaticamente distintas. Afirmamos isso com base em diversos estudos funcionalistas que têm evidenciado que o deslocamento de elementos para a periferia esquerda da oração costuma estar associado a uma posição temática, isto é, a uma informação já disponível no discurso precedente. Sob essa ótica, se fizéssemos as perguntas "O que você fez ontem?" e "Quando você comprou esse livro?", há uma grande probabilidade de a primeira levá-lo à resposta expressa em "a”, ao passo que a segunda à resposta expressa em "b". Portanto, a mudança na ordenação linear é motivada porque é cognitivamente menos custoso fazer uso de elementos já ativos na memória de trabalho para fazer o texto progredir.

De modo análogo, podemos pensar as categorias linguísticas no que se refere aos diferentes gêneros de texto ou sequências tipológicas. Os substantivos abstratos, por exemplo, apresentam papel fundamental para a progressão temática de textos expositivos e argumentativos, servindo-lhes, quase sempre, como estratégia de referenciação. Esse fato pode ser evidenciado pela natureza temática (e abstrata) dos textos dissertativos em oposição à natureza figurativa (concreta) dos textos narrativos. Como ilustração, observemos dois excertos de texto:

(5) A pureza é um ideal, uma visão da condição que ainda precisa ser criada, ou da que precisa ser diligentemente protegida contra as disparidades genuínas ou imaginadas. Sem essa visão, tampouco o conceito de pureza faz sentido, nem a distinção entre pureza e impureza pode ser sensivelmente delineada. (BAUMAN, 1998, p. 14) 
(6) Era uma vez um escorpião que estava na beira de um rio, quando a vegetação da margem começou a queimar. Ele ficou desesperado, pois, se $\varnothing$ pulasse na água, $\varnothing$ morreria afogado e, se $\varnothing$ permanecesse onde estava, Ø morreria queimado. (PLATÃO e FIORIN, 2001, p. 87).

Em (5), temos um trecho de texto dissertativo, do qual transpomos a seguinte cadeia referencial: a pureza $\rightarrow$ um ideal $\rightarrow$ uma visão da condi$\oint ̧ a \tilde{o}(. ..) \rightarrow$ essa visão. Como podemos observar, trata-se de um tema de natureza abstrata, cuja progressão temática se dá também pelo emprego de outros termos abstratos nas orações subsequentes. Em (6), por sua vez, temos a seguinte cadeia referencial extraída de uma sequência narrativa: um escorpião à ele $\rightarrow \varnothing \rightarrow \varnothing \rightarrow \varnothing \rightarrow \varnothing$. Neste caso, a progressão se dá pela retomada de um substantivo concreto, que, por estar plenamente ativo na memória, vai sendo representado por formas pronominais e elipses, as quais, embora cognitivamente mais leves, dão manutenção à natureza concreta do referente (escorpião). Desse modo, podemos observar como diferentes sequências tipológicas podem mobilizar recursos gramaticais distintos. Inclusive, o reconhecimento dessas diferentes categorias nos auxilia na identificação de diferentes sequências em um mesmo texto. Sendo assim, a formação de uma cadeia referencial com substantivos abstratos em um texto predominantemente narrativo pode indicar a existência de uma sequência dissertativa. Isso pode ser observado, por exemplo, em Crime e Castigo, de Fiódor Dostoiévski (2001, p. 20), quando a personagem Marmieládov fala sobre a diferença entre miséria e pobreza com o protagonista, Raskólnikov:

(7) Pobreza não é defeito, e isto é uma verdade. Sei ainda mais que bebedeira não é virtude. Mas a miséria, meu caro senhor, a miséria é defeito. Na pobreza o senhor ainda preserva a nobreza dos sentimentos inatos, já na miséria ninguém o consegue, e nunca. Por estar na miséria um indivíduo não é nem expulso a pauladas, mas varrido do convívio humano a vassouradas para que a coisa seja mais ofensiva; o que é justo, porque na miséria eu sou o primeiro a estar pronto para ofender a mim mesmo. 
Os recursos gramaticais também estão sujeitos à modalidade textual. Levando-se em consideração a conversação espontânea e o texto acadêmico, por exemplo, dois gêneros prototípicos da modalidade oral e escrita, respectivamente, podemos observar diversas distinções: apresentam diferentes unidades de análise, diferentes modos de organização, fazem uso de variedades linguísticas diferentes e, inclusive, de categorias linguísticas distintas. No que tange à conversação, por exemplo, é bastante comum a existência de marcadores discursivos, uma categoria gramatical típica do texto oral, cujos empregos costumam estar relacionados ao planejamento textual, bem como à manutenção ou ao assalto do turno de fala. Em (8), por exemplo, a expressão quer dizer está associada ao planejamento textual. Uma vez que o texto oral é formulado concomitantemente à sua realização, é natural que haja estruturas que promovam a correção de trechos que tenham sido expressos de maneira equivocada:

(8) Vão pagar vinte por cento e que quem quiser os quarenta por cento... quer dizer... quem exigir os quarenta por cento que eles pagam e mandam embora [RJ D2 355] (MARCUSCHI, 2005, p. 28).

Sendo assim, em nossa perspectiva, só uma abordagem contextualizada da gramática se justifica no ensino, na medida em que a análise linguística é promovida a partir do uso que fazemos da linguagem, sempre materializada em textos, como bem afirma Antunes (2014, p. 25):

Não existe uma gramática fora da língua. É na interação, é no cruzamento de todas as nossas ações verbais que a gramática vai internalizando e se consolidando, a ponto de se estabelecer como algo constitutivo do saber linguístico de todo falante. Nessa ação dos falantes, no decorrer do tempo, um pronome pode cair em desuso ou mudar de categoria, ou exercer uma função sintática diferente daquela que antes exercia.

Nesse sentido, a gramática é dinâmica e emergente, haja vista que novas estruturas e construções surgem na língua com o tempo. Ou seja, a 
despeito da existência e da manutenção de boa parte dos recursos linguísticos, formados em sincronias pretéritas do português, os usuários promovem usos inovadores, que se convencionalizam e, com o tempo, assumem função procedural. As inúmeras locuções prepositivas, por exemplo, mais recentes no português, como em virtude de, a despeito de, em face de, trazem mais expressividade à língua que as preposições simples, que apresentam propriedades semânticas mais opacas.

Em uma perspectiva de ensino de gramática pautado no texto, prioriza-se um método indutivo de ensino, em que o aluno constrói seu conhecimento gramatical pela observação da língua em uso. Sendo assim, é por meio das ocorrências concretas do uso linguístico que o aluno (e toda a classe) chega às generalizações linguísticas, de natureza mais abstrata. Sob essa ótica, ele deve observar não só as propriedades semânticas e morfossintáticas das categorias em estudo, como também as pragmáticas (relacionadas à situação de produção do discurso, sobretudo no que diz respeito à intencionalidade e aos papéis sociais desempenhados pelos interlocutores) e as discursivo-funcionais (relacionadas às questões da sequência tipológica, gênero e modalidade), sendo estas duas últimas - as pragmáticas e discursivo-funcionais - analisáveis somente em textos concretos, e não em frases descontextualizadas.

Em síntese, esse tipo de abordagem subordina a gramática ao texto, enxergando-a como um instrumento para a comunicação, e não como um fim em si mesmo. Trata-se de uma abordagem epilinguística, como defendem os PCN de Língua Portuguesa (BRASIL, 1998), que permite aos alunos operar sobre a própria linguagem e construir progressivamente paradigmas linguísticos a partir da análise do uso em diferentes contextos:

Deve-se ter em mente que tal ampliação (do repertório linguístico) não pode ficar reduzida apenas ao trabalho sistemático com a matéria gramatical. Aprender a pensar e a falar sobre a própria linguagem, realizar uma atividade de natureza reflexiva, uma atividade de análise linguística supõe o planejamento de situações didáticas que possibilitem a reflexão não apenas sobre os diferentes recursos expressivos utilizados 
pelo autor do texto, mas também sobre a forma pela qual a seleção de tais recursos reflete as condições de produção do discurso e as restrições impostas pelo gênero e pelo suporte. (BRASIL, 1998, p. 27).

\section{As relações gramaticais no nível transfrásico}

Descrever a gramática da língua com base em textos implica enxergar relações gramaticais em unidade superiores à frase e ao período. Tais relações podem ser concretizadas na superfície do texto, por meio de palavras que estabelecem a retomada de ideias e a progressão textual, bem como a conexão e articulação das ideias apresentadas no texto (isto é, por meio dos mecanismos de coesão) ou, ainda, ter sua materialidade evidenciada somente no contexto, em que pesam outros fatores de textualidade, como coerência, situacionalidade, informatividade, intencionalidade, aceitabilidade, focalização e intertextualidade (podendo esta última ser realizada na superfície do texto, através de alusões concretas ao texto original). Vale ressaltar que, sob esse ponto de vista, a gramática ganha maior nível de abstração. Não está associada somente às regras que explicam a formação da palavra e da frase, como também às "regras" gerais que possibilitam a comunicação humana.

Sob esse ponto de vista, refutamos a concepção de gramática da linguística gerativa, que "descreve a competência gramatical como sendo a capacidade que tem todo o usuário da língua de gerar sequências linguísticas gramaticais, isto é, consideradas por esses mesmos usuários como sequências próprias e típicas da língua em questão" (TRAVAGLIA, 2003, p. 17). Uma vez que agregamos propriedades pragmáticas e discursivo-funcionais às análises linguísticas, enxergamos a gramática como a totalidade do conhecimento linguístico dos falantes (GOLDBERG, 1995; HILPERT, 2014), o que inclui, por exemplo, a competência de interpretar e produzir textos, bem como o reconhecimento das características constitutivas de cada gênero de texto (tema, estilo e estrutura composicional). 
A gramática tradicional, por exemplo, atribui aos conectivos a função de encadeamento entre as orações de um período. Em se tratando de uma unidade maior, como o texto, essa função é assumida por diversos recursos linguísticos: além de conjunções, empregam-se palavras denotativas (inclusive, afinal, isto é, etc.), advérbios e locuções adverbiais (primeiramente, por fim, etc.). Trata-se de uma macrocategoria, a que a Linguística Textual convencionou chamar de operadores argumentativos, cuja função é o encadeamento entre enunciados por meio de uma orientação argumentativa do discurso (KOCH, 2002). Além deles, concorre também para a progressão textual o emprego de sintagmas nominais que encapsulam informações procedentes. Vejamos alguns exemplos:

(9) Em 1972 o Brasil, no momento mais duro do regime militar, comemorava de maneira ufanista o Sesquicentenário da Independência. Pouco antes, o então ministro da Educação, Jarbas Passarinho, conclamara os cineastas brasileiros a fazer filmes sobre temas históricos. "Os inconfidentes" é, por um lado, a resposta marota de Joaquim Pedro de Andrade a essa convocação. Por outro lado, é uma reflexão ousada e dolorosa sobre as ações e hesitações dos intelectuais em tempos de transformação política. Baseado nos chamados 'autos da devassa'e lançando mão fartamente dos poemas dos próprios inconfidentes, o filme retrata com ironia e distanciamento brechtianos o cipoal de intrigas e traições que resultou na revolução abortada e no enforcamento de Tiradentes. [Folha de São Paulo, 7 set.2008] (LOPES, 2010, p. 91).

(10) [...] Pois mais vale que pessoas tão sensíveis passem longe de 'Tragam-me a Cabeça de Alfredo Garcia' (TC Cult, 11h45; não recomendado para menores de 12 anos). Pois alguém a trará - está feito o aviso. E vai executar um longo trajeto com a cabeça dentro de um saco. Será que essa cabeça, devida ao fantástico Sam Peckinpah, vai chocar tanto quanto as diabruras, também fantásticas, do Zé do Caixão? Posso estar errado, mas esse tipo de reação visa objetos específicos. Lembra a das pessoas em transe histérico para quem o programa de rádio no qual Orson Welles, em 1938, representava a invasão da Terra por 
alienígenas era, de fato, o fim dos tempos. [Folha de São Paulo, 31 ago.2008] (LOPES, 2010, p. 67).

Em (9), as expressões destacadas "por um lado" e "por outro lado" são conectores macrotextuais e, por isso, operadores argumentativos, cuja função é apresentar argumentos em relação de oposição. Podem ser interpretados como duas partes de uma mesma construção correlata opositiva (ou adversativa), na medida em que o emprego da primeira subparte exige a instanciação da segunda. Vale ressaltar que esse par correlativo tem sido largamente empregado na remissão a porções maiores de texto. É natural, por exemplo, encontrarmos ocorrências em que cada subparte introduza um parágrafo inteiro, com vários períodos intervenientes. Em (10), por sua vez, o sintagma nominal "esse tipo de reação" representa um tipo de encapsulamento, isto é, uma espécie de tematização-remática (SCHWARZ, 2000), na medida em que o elemento anafórico é, ao mesmo tempo, um elemento de referência e de predicação. Representa um tipo de progressão em que uma predicação precedente (ou, inclusive, um conteúdo discursivo construído intersubjetivamente) transforma-se ad hoc em tópico discursivo. Podemos observar, na ocorrência supracitada, que "esse tipo de reação" se refere à provável recepção dos espectadores quanto ao conteúdo do filme, expresso em períodos antecedentes.

Para além da superfície e da materialidade concreta do texto, as relações gramaticais devem ser observadas também contextualmente, levando-se em consideração questões de ordem pragmática (como intencionalidade do falante, relação entre os interlocutores, por exemplo) e de ordem discursivo-funcional (como questões do gênero discursivo e da modalidade textual). Observemos, como ilustração, a transcrição de um texto publicitário veiculado na Revista Imprensa, em maio de 1995 (PLATÃO e FIORIN, 2001, p. 413): 
Transcrição do texto (grifos nossos):

Aruba, 20 de fevereiro de 1995.

Queridos Ana e Paulo,

Aqui é o velho amigo Bernardo, falando diretamente de Aruba. Estamos nos divertindo muito. Nos mergulhos, podemos conhecer melhor os hábitos do Hippocampus Guttulatus. O santuário ecológico de Bubali também é extraordinário. $\mathrm{E}$ as cavernas com desenhos indígenas, então? Vocês iriam adorar. Descobrimos também a fonte da juventude. E é de água salgada (ah! ah! ah!). À noite, parecemos dois adolescentes. Andamos de mãos dadas e namoramos como nos velhos tempos. Até no cassino! $\mathbf{O}$ azul do mar é incrível e a areia branquinha... A praia é bonita. Ontem, eu brinquei de castelinho. $O$ meu baldinho é verde e o da Elisa é vermelho. AQUI É LEGAL. UM BEIJO BERNARDO².

Como podemos observar, o enunciador do texto defende, em seu discurso, uma transformação positiva para quem visita Aruba: a de voltar a desfrutar a vida como uma criança. Sendo o mar de Aruba a fonte da juventude, a mudança de Bernardo se dá na conceptualização do mundo como uma criança, não só no que se refere ao ponto de vista, como também à própria expressão linguística. Ao final do texto original, veiculado na revista, é possível verificar que a transformação de Bernardo se materializa de diferentes modos: na expressão de frases curtas e de conteúdo simples, bem como na própria caligrafia e no espelhamento de algumas letras (o traço vai se tornando infantil e o locutor chega a escrever o "B" e o " $\mathrm{R}$ " do próprio nome ao contrário, aspectos muito comuns em crianças em processo inicial de alfabetização). Entendemos que essas escolhas são propositais, e não inadequadas, porque reconhecemos a intenção subjacente ao texto publicitário, que visa a interpelar seu enunciatário pela emoção e pela arte. Portanto, nosso conhecimento do gênero de texto e da intencionalidade do interlocutor nos leva a aceitar a pertinência tanto do conteúdo

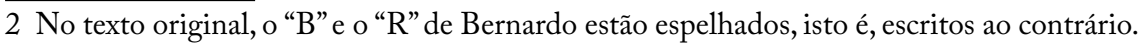


quanto da forma como esse conteúdo é veiculado. O mesmo procedimento não seria produtivo, por exemplo, se tivéssemos lidando com um texto da esfera acadêmica.

Por conseguinte, urge que repensemos nossa concepção de gramática. Como afirma Antunes (2010, p. 39), "não basta conceber o texto como uma espécie de super-sentença, algo como uma unidade gramatical mais ampla, uma espécie de período grande, que se forma juntando-se unidades menores, em vistas à formação de uma unidade maior”. Desse modo, em consonância com Val (2002, p. 10), argumentamos que a gramática “diz respeito ao conjunto de conhecimentos e habilidades dos falantes que lhes possibilita interagir linguisticamente produzindo e interpretando textos, falados e escritos, nas diversas situações de sua vida”, isto é, um conhecimento que extrapola a noção de regra abstrata para a construção de períodos e prevê os níveis textuais e discursivos como suas subpartes.

\section{A variação linguística também recobre os usos cultos da linguagem}

Normalmente, quando ouvimos falar em variação linguística, remetemo-nos, sobretudo, aos usos desviantes da norma padrão da língua, de modo a mostrar que existem contextos em que tais usos podem ser considerados adequados. Um exemplo bastante caricato são as tirinhas do Chico Bento, na medida em que, recorrentemente, os livros didáticos selecionam esses textos para o tratamento da variação. Transcrevemos abaixo um diálogo de uma das tirinhas de Maurício de Souza, entre as personagens Rosinha e Chico Bento ${ }^{3}$ :

- As nuvem faiz umas forma bunita!

- Forma di passarinho, coração, elefante...

- I aquela ali, Chico? Qui forma qui tem?

- Di chuva!!

3 Tirinha disponível no site: http://uemasulletras.blogspot.com/2017/05/fala-do-chico-bento-francisco-antonio.html - Acesso em: 28 out.2018. 
Acima, podemos observar variação tanto de ordem fonológica (bunita, $i$, di, qui, faiz) quanto morfossintática (as nuvem), com o intuito de materializar a variedade caipira. Não obstante, além de a variação fonológica ser forçada (na medida em que diversas variedades linguísticas, como a carioca, também realizam assim essas formas na oralidade), existe variação na própria norma culta. Por isso, daqui por diante, trataremos tanto da variação dos usos cultos da linguagem (levando em consideração o emprego de diferentes formas para um mesmo contexto) quanto da variabilidade (no que se refere às diferentes funções sintáticas, semântico-pragmáticas ou discursivas de um mesmo item ou construção).

No que tange ao primeiro ponto (a variação dos usos cultos da linguagem), Vieira (2009) argumenta que cabe ao ensino conceber os elementos de natureza formal em contínuos (cf. BORTONI-RICARDO, 2004), que "vão do [+ formal] ao [-formal], do [+escrito/ -oral] ao [-escrito /+oral], do [+culto/-popular] ao [-culto/+popular]". Ou seja, quando falamos de norma culta ou padrão (sem a preocupação aqui com a distinção entre as duas normas), temos de ter em mente que esta também permite variação, isto é, é possível empregar construções diversas sem deixar de corresponder àquilo que preconiza a norma. Paralelamente, é possível que a própria escolha de uma forma variável no lugar de outra seja significativa e impacte o processo de significação do texto. Vejamos um exemplo:

(11) O Diretor Geral de um Banco estava preocupado com um jovem e brilhante Diretor, que, depois de ter trabalhado durante algum tempo com ele, sem parar nem para almoçar, começou a ausentar-se ao meio-dia. Então, o Diretor Geral do Banco chamou um detetive e disse-lhe: - Siga o Diretor Lopes durante uma semana, durante o horário de almoço.

O detetive, após cumprir o que lhe havia sido pedido, voltou e informou:

- O Diretor Lopes sai normalmente ao meio-dia, pega o seu carro, vai a sua casa almoçar, faz amor com sua mulher, fuma um dos seus excelentes cubanos e regressa ao trabalho. 
Responde o Diretor Geral:

- Ah, bom, antes assim. Não há nada de mal nisso.

Logo em seguida o detetive pergunta:

- Desculpe. Posso trata-lo por tu?

- Sim, claro - respondeu o Diretor surpreendido!

- Bom então vou repetir. O Diretor Lopes sai normalmente ao meio-dia, pega o teu carro, vai a tua casa almoçar, faz amor com a tua mulher, fuma um dos teus excelentes cubanos e regressa ao trabalho.

A Língua Portuguesa é mesmo fascinante!!!

(VIEIRA, 2009, p. 63).

Como podemos perceber, embora as formas seu/teu e sualtua sejam formas cultas do português, elas apresentam também variação de sentido. Ao passo que as formas seu/sua são ambíguas, na medida em que podem referir-se tanto à segunda quanto à terceira pessoa do discurso, o mesmo não ocorre com teu/tua, sempre dirigidos à segunda pessoa. É exatamente na desconstrução dessa ambiguidade que se constrói o efeito de humor desse texto. Nesse sentido, podemos dizer que, enquanto seu/teu e sua/tua são variáveis em alguns contextos, com a manutenção do mesmo valor de verdade, noutros seu/sua podem apresentar variabilidade, na medida em que uma mesma forma pode representar mais de um sentido. Vejamos um outro exemplo de variabilidade:

(12) Nessas conversas amenas com José Bonifácio, ele me deu lições curiosas. Com aquele espírito de humor que tinha, me disse certa feita: "Gastão, quando você tem um amigo chato que telefona dizendo que o vai visitar e se esquece da hora de sair, você fala o seguinte: estou com minha mulher saindo para te visitar. Espera aí na sua casa, porque vou aí. Aí, você sai à hora que quiser, e não fica aturando o sujeito até 1 hora, 2 horas da manhã”. (SABOYA, 2018, p. 29)

(13) SR JOSÉ LUÍS ESCANHOELA - [...] Os municípios têm muita dificuldade em obter, por falta de informações, de obter recursos de 
como fazer. Então, quando se tem um escritório que faça isso, ou pessoas especializadas para isso, eles se socorrem deles. Porque há dificuldade de vir um prefeito a Brasília, pedir a um Deputado ou coisa assim; é muito difícil. SR. ITAMAR FRANCO - Não. Espera aí. V. Sa. diz que nunca veio a Brasília. Então, qual é a dificuldade? O escritório de V. Sa. nunca veio à Brasília; tinha aqui apenas um intermediador; uma hora era o Dr. Paulo, outra hora foi o Dr. Boni? (SABOYA, 2018, p. 31).

Em (12) e (13), temos destacada a expressão "espera aí". Em cada uma das ocorrências, observamos funções distintas. Em (12), espera apresenta a função de verbo pleno locativo (isto é, a pessoa deve permanecer no lugar em que está) e ai é um locativo, que remete ao local onde o interlocutor está no momento da fala. Em (13), por sua vez, a expressão funciona como um marcador discursivo. $\mathrm{O}$ verbo e o locativo perdem suas propriedades de espacialidade, e o objetivo do locutor é o de assaltar o turno, com $o$ intuito de apresentar um contra-argumento.

Por conseguinte, no que tange ao estudo da variação e da variabilidade, cabe ao professor refletir sobre a pluralidade linguística para além das noções prototípicas de variação, associadas a "fatores geográficos, socioeconômicos, de faixa etária, de gênero (sexo), da relação estabelecida entre os falantes e do contexto de fala" (BRASIL, 1998, p. 29). Nesse sentido, é preciso entender também, de um lado, a variação no que diz respeito às diferentes escolhas linguísticas para um mesmo contexto de uso (levando-se em consideração o gênero de texto, sua situação de produção e o papel desempenhado por seus enunciadores), bem como a variabilidade, no que tange à dinamicidade da estrutura linguística, suscetível a reinterpretação semântica ou, até mesmo, a recategorização morfossintática quando em diferentes contextos de uso.

\section{Para além da análise linguística: o estudo das diferentes semioses}

Como sabemos, durante muito tempo, apenas a língua (o código) foi tomada como objeto de aprendizagem nos estudos da linguagem. Nesse 
sentido, a imagem, o ritmo, a gestualidade, o movimento etc ou eram desconsiderados ou recebiam tratamento periférico nos estudos da significação. A imagem, por exemplo, quase sempre era vista como uma espécie de decoração ou de redundância dos conteúdos que já haviam sido expressos por meio da linguagem verbal.

Hoje, no entanto, com a massiva presença da mídia e dos gêneros digitais, os textos multissemióticos assumem elevada importância. Muitas vezes, a manipulação e/ou construção de sentidos se dá por intermédio de outras semioses. Conforme já argumentamos no Capítulo 1, em era de pós-verdade, faz-se mister o desenvolvimento de uma competência leitora que torne os cidadãos capazes de combater as Fake News, de modo a reconhecer que, assim como a língua constrói um ponto de vista, assim também o faz a edição de um vídeo e de uma imagem.

Dadas a complexidade e a especificidade exigida para o estudo das diferentes semioses, bem como o espaço de que dispomos neste capítulo, optamos, nesta seção, por discorrer sobre os seguintes pontos: 1) a base fenomenológica da semiótica; 2) a diferença entre plano de conteúdo e plano de expressão; 3) o nível fundamental e o emprego das isotopias na reiteração dos temas e figuras. Reconhecemos que essa não é uma abordagem completa e suficiente para um estudo semiótico, mas acreditamos que tais conhecimentos podem nos trazer algumas reflexões iniciais para uma investigação do texto multissemióticos em sala de aula.

\section{A base fenomenológica da semiótica}

De base fenomenológica, a semiótica estabelece-se como uma quase-ciência capaz de investigar os diferentes modos como apreendemos qualquer coisa que esteja disponível à mente, desde um cheiro, uma cor, um ruído etc. Segundo Santaella (2002, p. 10), a semiótica prescreve uma gramática que

[...] nos fornece as definições e classificações para a análise de todos os tipos de linguagens, signos, sinais, códigos, etc., de qualquer espécie e 
de tudo que está neles implicado: a representação e os três aspectos que ela engloba, a significação, a objetivação e a interpretação. Isso assim se dá porque, na definição de Peirce, o signo tem uma natureza triádica, quer dizer, ele pode ser analisado: em si mesmo, nas suas propriedades internas, ou seja, no seu poder para significar; na sua referência àquilo que ele indica, se refere ou representa; e nos tipos de efeitos que está apto a produzir nos seus receptores, isto é, nos tipos de interpretação que ele tem o potencial de despertar nos seus usuários.

Desse ponto de vista, acredita-se que nossos conhecimentos vão sendo organizados na mente pela experiência que temos com o mundo. Isso significa que, assim como criamos categorias e padrões linguísticos a partir de metodologia indutiva (do particular para o geral), isto é, aprendemos a ordenação sintática (SVO) do português, as categorias morfológicas das palavras e as empregamos adequadamente nos enunciados que produzimos, também formamos categorias e padrões de significado fora do domínio específico do código linguístico. Portanto, a reincidência de uma determinada cor em contextos determinados, com significados específicos, por exemplo, leva-nos, inconscientemente, à conceptualização de certos sentidos em detrimento de outros. É isso que nos leva, muitas vezes, a associar a cor preta a luto ou terror, ou, inclusive, a associar fumaça a fogo, pois nossa experiência apresenta esses elementos como termos relacionados.

Para além dessas questões relacionadas à experiência física e concreta que temos com o mundo, a semiótica analisa também textos, isto é, produtos que foram construídos para causar determinado(s) efeito(s) de sentido. Desse modo, assim como um objeto real que vemos diante de nossos olhos aponta para sua existência inequívoca, uma imagem, como uma fotografia, por exemplo, é capaz de reproduzir efeito análogo sobre nós. Isto é, muito embora a fotografia possa ser uma reelaboração do real, muitas vezes, temos a impressão de que ela captou a realidade mesma, sem alterá-la.

De posse desse conhecimento, muitos textos publicitários, por exemplo, que têm como objetivo persuadir-nos a adquirir determinados 
serviços ou produtos, criam e manipulam imagens para obter determinado efeito de sentido. Nos anúncios de cigarro, hoje proibidos, era natural sua associação a pessoas saudáveis, como estratégia de diminuir os efeitos nocivos do tabagismo. Como exemplo, podemos citar duas publicidades de cigarro: uma da marca Camel e outra da Marlboro. Na primeira, há uma cantora profissional fumando enquanto canta; na segunda, um caubói de porte atlético, fumando ao lado de um cavalo ${ }^{4}$.

Conforme sabemos, uma vez que os efeitos nocivos do cigarro incidem diretamente nos órgãos do aparelho fonador, especialmente os pulmões, os anúncios publicitários constroem imagens que contradigam esses malefícios. No primeiro caso, uma cantora profissional fuma enquanto canta, a despeito de o cigarro, comprovadamente, prejudicar a voz; no segundo, um esportista saudável fuma em seu tempo livre, muito embora o cigarro diminua a capacidade respiratória com o tempo.

Esse tipo de estratégia é muito recorrente nos textos de publicidade. A fórmula parece ser a seguinte: acrescente qualidades que se oponham aos malefícios do produto ou, ainda, apresente propriedades que sejam de interesse do consumidor, muito embora tais propriedades não sejam inerentes ao produto. Os anúncios de cerveja fazem uso, por exemplo, dessa última estratégia. As cervejas nada têm a ver com mulher bonita seminua, sol ou praia. No entanto, no Brasil, os comerciais de cerveja estão associados direta e recorrentemente a essas propriedades, como modo de interpelar seu principal público: o masculino.

Cabe ressaltar que as imagens (sejam elas estáticas ou em movimento), de modo geral, podem nos interpelar de três diferentes maneiras:

a) através do referente, isto é, o objeto que está representado é visto como a representação da própria realidade. Assim, quando olhamos um anúncio de uma pizza em embalagem de supermercado,

\footnotetext{
${ }^{4}$ As imagens estão disponíveis nos sites a seguir: https://addio.ecrater.com/p/14199448/ camel-cigarettes-print-ad-sexy - Acesso em 29/10/2018. / http://bhassth.blogspot. com/2014/01/eric-lawson-marlboro-man.html - Acesso em: 29 out.2018.
} 
temos a impressão de que o produto, quando pronto, corresponderá exatamente àquele demonstrado pela foto da embalagem;

b) através das qualidades atribuídas ao referente, conforme vimos nos anúncios de cigarro e cerveja acima, aos quais se atribuem características que não são inerentes aos produtos;

c) através de conceitos de ordem simbólica. Neste último caso, as relações de sentido se dão num nível mais abstrato de significação, podendo interpelar seu interlocutor de maneira ainda menos consciente.

Como exemplo deste último tipo, retomamos a campanha publicitária dirigida ao público homossexual feminino na França, apresentada no Capítulo $1^{5}$. Nela, podemos observar uma aranha negra em uma função bastante simbólica. Ao ocupar o papel do homossexual ativo, sendo um animal peçonhento normalmente associado à feminilidade, a aranha representa o perigo, isto é, o carrasco que seduz o outro no intuito de fazer-lhe mal (no caso, transmitir-lhe o vírus do HIV). Assumimos que esta se trata de uma análise mais simbólica e abstrata, na medida em que mobiliza uma série de conhecimentos e inferências para seu entendimento.

Vale lembrar que são variadas as semioses. Desse modo, o ritmo e o movimento, entre outros, também podem ser vistos como algo significativo. Se observarmos o gênero canção, por exemplo, é natural que as letras de música, de acordo com o seu conteúdo, apresentem melodias distintas. É fácil notar, por exemplo, que canções alegres costumam apresentar melodias de ritmo acelerado, ao passo que as canções tristes apresentam melodias de ritmo lento. Isso significa que o uso de uma melodia ou de outra pode impactar a significação do texto. Trataremos mais desse último ponto na próxima seção.

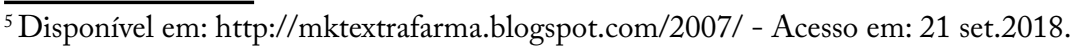




\section{A diferença entre plano de conteúdo e plano de expressão}

Por plano de expressão, entendemos as diferentes semioses, como a linguagem verbal, a imagem, o ritmo, a melodia, o movimento, a gestualidade etc. Por plano de conteúdo, por sua vez, entendemos os sentidos veiculados pelos diversos planos de expressão. A divisão entre esses dois planos é bastante pertinente à análise de textos multissemióticos, isto é, que apresentam mais de uma semiose.

Como ilustração, observemos inicialmente a letra da música "desce”, de Arnaldo Antunes:

Desce do trono, rainha

desce do seu pedestal

de que te vale a riqueza sozinha,

enquanto é carnaval?

desce do sono, princesa

deixa o seu cetro rolar

de que adianta haver tanta beleza

se não se pode tocar?

hoje você vai ser minha

desce do cartão postal

não é o altar que te faz mais divina

Deus também desce do céu

desce das suas alturas

desce da nuvem meu bem

por que não deixa de tanta frescura

e vem para a rua também?

\section{Arnaldo Antunes (do álbum "silêncio")}

A canção de Arnaldo Antunes foi gravada em dois diferentes ritmos: primeiro em uma melodia bastante desacelerada e disfórica; outra em uma melodia acelerada e eufórica, um ritmo de marchinha de carna- 
$\mathrm{val}^{6}$. A leitura que fazemos, como enunciatários, em cada uma das versões é diferente. No ritmo desacelerado, temos a impressão de que o eu lírico está muito triste, sentindo-se só e desiludido por um amor não correspondido. Sua felicidade só pode ser alcançada por intermédio da realização desse amor. No ritmo acelerado, por sua vez, construímos a imagem de um eu lírico folião, que flerta com uma mulher na sacada. Nesse caso, a falta de correspondência amorosa não acarreta a infelicidade do eu lírico, que, muito provavelmente, tentará a mesma abordagem com uma próxima foliã.

Como podemos observar, pelas reflexões feitas, cada plano de expressão aponta um determinado conteúdo, e a conjunção desses conteúdos em um mesmo texto pode implicar diferentes efeitos de sentido. Ademais, planos de conteúdo distintos podem servir para a construção de um contraprograma, isto é, para a negação e conteúdos expressos em outros planos de expressão. Como ilustração, falaremos um pouco do documentário "Um lugar ao sol", do cineasta baiano Gabriel Mascaro.

Nesse documentário, Gabriel Mascaro entrevista uma série de moradores de coberturas brasileiras, que falam tão-somente sobre a experiência de viver em cobertura. Fica claro, ao longo do texto, que todos os entrevistados produzem um discurso positivo sobre si mesmos e sobre o fato de morarem em uma cobertura. Não obstante, a despeito de os entrevistados se empenharem na preservação da própria face e de os documentaristas não se manifestarem ao longo do vídeo (não ouvimos suas vozes ou os vemos no vídeo), o texto assume um viés crítico. Isso se dá porque o documentarista interpõe alguns outros planos de expressão com conteúdos contrários, de modo a construir um contraprograma. As cenas a que assistimos são intercaladas com músicas tristes, de ritmo desacelerado, e com imagens desfocadas de pessoas vivendo nas ruas, catando lixo

\footnotetext{
${ }^{6}$ No momento de escrita desse texto, as duas versões estão disponíveis nos seguintes canais do YouTube:

a) https://www.youtube.com/watch?v=W1E1wR63ATY ;

b) https://www.youtube.com/watch?v=bBY0jLqGDpo
} 
para sobreviver. Ou seja, o documentarista, sem precisar dizer objetivamente, visa a mostrar que o privilégio de alguns tem como consequência a miséria de muitos.

Acreditamos que o estudo dos planos de conteúdo e dos planos de expressão é de suma importância, não apenas para a apreensão dos significados pretendidos, mas, sobretudo, para compreender que a significação é manipulável, muitas vezes de maneira criminosa. Em uma sociedade em que se produzem Fake Nerws em massa, entender como essas linguagens se sobrepõem para criar um novo sentido é importante para o próprio exercício da cidadania.

\section{O nível fundamental e o emprego das isotopias na reiteração dos temas e figuras}

Hoje, as abordagens discursivas propõem que não existem textos neutros e ingênuos. Todo texto diz o que diz para atingir determinados objetivos comunicativos. Nesse sentido, até mesmo uma narrativa, isto é, um texto figurativo, apresenta temas subjacentes e visa a construir um determinado ponto de vista sobre esses temas. Vejamos dois exemplos:

O Lobo e o cão (La Fontaine)

Um lobo espantosamente magro encontrou um cão gordo e bem nutrido. Não podendo atacá-lo, chegou-se a ele humildemente, e o cão lhe disse que, se desejasse viver tão bem quanto ele, era só acompanhá-lo até sua casa. Mas, quando o lobo viu a marca que a coleira deixara no pescoço do cão, alegou que preferia passar fome a perder a liberdade.

Moral da história: a liberdade é o bem mais precioso que temos. Por isso, é preciso tudo fazer e até sacrificar-nos para mantê-la.

$\mathrm{Na}$ fábula de La Fontaine, temos um texto cujo tema é o confronto entre liberdade e dominação. Na perspectiva da Semiótica do Discurso, dizemos que qualquer texto apresenta um nível fundamental (ou pro- 
fundo), que se caracteriza por duas ideias contrárias. Dessa forma, quando se afirma X, nega-se seu contrário (não-X). Nesse texto, observamos que se afirma a liberdade e nega-se a dominação, muito embora esta última possa apresentar certas vantagens, como a comida em abundância.

Esses temas, no plano discursivo da narrativa, figurativizam-se por meio de isotopias. Sendo assim, a liberdade é representada pelo "lobo espantosamente magro" e pelas vicissitudes da liberdade, como a probabilidade de passar fome; a dominação, por sua vez, é representada pelo "cão gordo e bem nutrido", mas que tem marcas de coleira no pescoço.

Vale ressaltar que as isotopias não são imanentes, mas, sim, construídas no discurso. Desse modo, o ponto de vista, na representação de temas e figuras também pode ser a consequência de uma elaboração do enunciador, que visa a determinados efeitos de sentido. De 2018 em diante, por exemplo, em virtude da elevada polarização política, é muito comum que vejamos a oposição, no nível fundamental, entre as ideias de comunismo e democracia, sendo que tais conceitos não são contrários, haja vista que comunismo se opõe a capitalismo, ao passo que democracia se opõe a ditadura.

Vejamos um último exemplo em que os contrários são reconfigurados para a construção de um determinado efeito de sentido. Em 2007, surgiu na mídia uma campanha de base feminista, cujo objetivo era o de defender a igualdade de direitos entre homens e mulheres. Não obstante, a página "Orgulho de ser hétero" se apropriou de diversas imagens e construiu novas personagens, de caráter bastante pejorativo. Em uma das peças, lê-se o seguinte: "Femineuza diz que ninguém nasce homem ou mulher..." “... mas homossexuais nascem homossexuais". ${ }^{7}$

De um modo geral, esse texto se configura como se, no nível fundamental, "feminismo" fosse o contrário de "machismo", isto é, o feminismo estaria associado à superioridade da mulher, e não à luta por direitos iguais. Desse ponto de vista, várias foram as peças da "campanha" com o objetivo de desconstruir e ridicularizar as ideias feministas. Temos, nesta última citação, uma deturpação de uma citação de Simone de Beauvoir, em sua obra $O$

\footnotetext{
${ }^{7}$ Disponível em: https:/pt.memedroid.com/memes/detail/1814054 - Acesso em 29 out.
} 2018. 
segundo sexo, cujo objetivo era abordar o papel social da mulher como uma construção social, que em nada corresponde à sua orientação sexual.

$\mathrm{Na}$ peça em questão, constrói-se a ideia estapafúrdia de que a fala de Simone de Beauvoir sugere que a criança só pode se reconhecer como sendo homem ou mulher quando na fase adulta. E, tomada dessa forma, a oração coordenada adversativa "mas homossexuais nascem homossexuais" é colocada ali para construir um paradoxo, um pensamento absurdo, como forma de desqualificar o pensamento feminista.

Por fim, acreditamos que as categorias semióticas aqui apresentadas, no que tange aos diferentes planos de expressão e de conteúdo, bem como aos temas fundamentais e às isotopias do nível discursivo dos textos, auxiliem os leitores em um trabalho inicial com os textos multissemióticos em sala de aula. Não obstante, caso desejem maior aprofundamento para o trabalho com as diferentes semioses, recomendamos que estude mais detidamente as teorias semióticas, cuja complexidade não cabe em um capítulo.

\section{Exercícios}

1. Por que defendemos que a gramática é plural?

2. Defendemos, neste texto, que a gramática está associada à totalidade do conhecimento do falante. Explique.

3. O que podemos entender por variação e variabilidade linguísticas?

4. Por que é importante analisar as diferentes semioses?

5. Segundo o texto, de que maneiras as imagens podem nos interpelar?

6. Diferencie plano de conteúdo de plano de expressão.

7. Conceitue nível fundamental e isotopia.

\section{Resumo}

No início deste capítulo, tratamos do ensino tradicional de gramática, pautado quase exclusivamente na transmissão de uma gramática teórica e normativa, sob a defesa de que esses modelos eram sufi- 
cientes para a expressão linguística nos diferentes gêneros de texto, tanto da modalidade oral quanto da escrita. Em sequência, problematizamos esse ponto de vista, na medida em que o domínio de uma gramática cujo escopo máximo é o período não nos torna capazes de escrever bons textos. Para tanto, faz-se necessária uma abordagem gramatical que abarque unidades textuais, mais especificamente, é necessária uma gramática do texto.

Uma gramática que tenha o texto como unidade de análise extrapola os níveis fonológico, morfológico, sintático e semântico da língua. Desse ponto de vista, incluem-se questões de ordem pragmática (associadas, sobretudo, à intencionalidade do falante e aos papéis desempenhados pelos interlocutores em uma dada situação de produção do discurso) e de ordem discursivo-funcional (relativa às sequências tipológicas, gêneros e modalidades textuais). Como vimos, estes últimos níveis impactam na análise que fazemos da língua, na medida em que tanto as intenções do enunciador quanto a sequência tipológica, o gênero e a modalidade costumam mobilizar recursos linguísticos distintos.

Paralelamente, uma abordagem transfrásica da gramática permite- nos enxergar novas unidades, antes consideradas "inexistentes". Os operadores argumentativos por um lado e por outro lado, por exemplo, formam um par correlativo que, via de regra, tem como escopo unidades transfrásicas, às vezes, inclusive da dimensão de parágrafos inteiros. Paralelamente, refutamos uma concepção de gramática que se restringe à capacidade de gerar sequências linguísticas procedurais no nível da frase e lhe agregamos propriedades pragmáticas e discursivo-funcionais. Assim, enxergamos a gramática como a totalidade do conhecimento linguístico dos falantes, de modo que a competência de interpretar e produzir textos, bem como as características constitutivas de cada gênero fazem parte de seu bojo.

Falamos também da questão da variação e da variabilidade linguísticas. Em um primeiro momento, dissociamos a ideia de que variação diz respeito somente aos usos desviantes da norma culta da língua, na medida em que, mesmo em contextos mais formais, a língua 
dispõe de escolhas que garantem o mesmo valor de verdade em um mesmo contexto de uso. Em seguida, tratamos da variabilidade, que se caracteriza pela dinamicidade da gramática, que possibilita novos sentidos e/ou novas funções para um mesmo item ou construção.

Em uma segunda parte do texto, passamos a abordar a importância de um trabalho didático com as outras semioses no ensino. Hoje, entendemos que todas as semioses são significativas e vêm sendo amplamente exploradas na produção de sentidos, muitas vezes, inclusive, de maneira inadequada e criminosa, como podemos observar nas atuais Fake Nerws. Como vimos, o conhecimento dos diferentes planos de conteúdo e de expressão pode nos tornar mais hábeis na interpretação e compreensão dos textos multissemióticos, na medida em que cada plano de expressão carreia sentidos. Inclusive, é comum que os conteúdos expressos pelos diferentes planos de expressão se complementem ou se contradigam, criando um efeito de sentido que nos interpela mais pela emoção do que pela razão.

Por fim, abordamos o nível fundamental e o emprego das isotopias nos textos. Vimos que todo texto, mesmo quando figurativo, apresenta temas subjacentes e defende um determinado ponto de vista, que pode ser inferido pela recorrência das isotopias no nível discursivo. Além disso, vimos que, muitas vezes, um enunciador manipula a representação de seus temas para criar novos efeitos de sentido sobre seu enunciatário.

\section{Referências}

ANTUNES, Irandé. Análise de textos. Fundamentos e práticas. São Paulo: Parábola, 2010.

ANTUNES, Irandé. Gramática contextualizada. Limpando “o pó das ideias simples”. São Paulo: Parábola, 2014.

AZEVEDO, Jaqueline Cristina Rocha Marcondes. Usos funcionais do enfim em Lingua Portuguesa. Dissertação de mestrado. Niterói: UFF, 125p., 2018.

BAUMAN, Zygmunt. O mal-estar da pós-modernidade. São Paulo: Jorge Zahar, 1998.

BORTONI-RICARDO, Stella Maris. Educação em lingua materna: a sociolinguística na sala de aula. São Paulo: Parábola, 2004. 
BRASIL. Secretaria de Ensino Fundamental. Parâmetros Curriculares Nacionais de Lingua Portuguesa. 30 e $4^{\circ}$ ciclos. Brasília: MEC, 1998.

BRASIL. Secretaria de Educação Básica. Base Nacional Comum Curricular. Brasília: MEC, SEB, 2018.

DOSTOIÉVSKI, Fiódor. Crime e castigo. São Paulo: Editora 34, 2001.

GOLDBERG, Adele. A construction Grammar Approach to Argument Structure. Chicago: The University of Chicago Press, 1995.

GRAMA, Daniela Faria. Problemas de coesão na escrita dos gêneros discursivos da ordem do relatar: 'notícia e relato'. Horizonte cientifico. Uberlândia, v. 7, n. 1. p. 1-30, 2013.

HILPERT, Martin. Construction grammar and its application to English. Edimburgo: Edinburg Textbooks, 2014.

KOCH, Ingedore Grunfeld Vilaça. Argumentação e linguagem. São Paulo: Cortez, 2002.

LOPES, Monclar Guimarães. Encapsulamentos semânticos em perspectiva discursivo-funcional. Dissertação de mestrado. Niterói: UFF, 219p, 2010.

MARCUSCHI, Luiz Antônio. Linguística do texto: o que é como se faz. Recife: UFPE, 1983.

MARCUSCHI, Luiz Antônio. Da fala para a escrita. Atividades de retextualização. São Paulo: Cortez, 2005.

PLATÃO, Francisco; FIORIN, José Luiz. Lições de texto: leitura e redação. São Paulo: Ática, 2001.

SABOYA, Flávia. Estágios da construcionalização gramatical de [IRLoc]RA. In: SEMINÁRIO NACIONAL E IX SEMINÁRIO INTERNACIONAL DO GRUPO DE ESTUDOS DISCURSO \& GRAMÁTICA, 22., 2018, Niterói, Anais.... Niterói, 2018, p. 25-37.

SANTAELLA, Lúcia. Semiótica aplicada. Rio de Janeiro: Lucerna, 2002.

SCHWARZ, Monika. Indirekte Anaphern in Texten. Tübingen: Niemeyer, 2000.

TRAVAGLIA, L. C. Gramática e interação: uma proposta para o ensino de gramática. São Paulo: Cortez, 2003.

VAL, Maria da Graça Ferreira da Costa. A gramática do texto, no texto. Revista de estudos da linguagem. Belo Horizonte, v. 10, n.2, p. 107-133, 2002.

VIEIRA, Sílvia Rodrigues. Variação linguística, texto e ensino. (Com)textos linguísticos. Vitória, n. 3, p. 53-75, 2009. 



\section{Sobre os autores}

\section{Monclar Guimarães Lopes}

é professor adjunto do Departamento de Letras Clássicas e Vernáculas e do Programa de Pós-Graduação em Estudos da Linguagem da Universidade Federal Fluminense. É doutor em estudos linguísticos e mestre em língua portuguesa pela Universidade Federal Fluminense. É especialista em Língua Portuguesa e Literatura Brasileira e graduado em Letras-Inglês pela Ferlagos. É vice-líder do Grupo de Estudos D\&G-UFF e membro pesquisador do Grupo de Pesquisa Conectivos e Conexão de Orações (CCO) - ambos sediados pela UFF, além de membro do Grupo de Trabalho Descrição do Português da ANPOLL.É autor de artigos publicados em revistas especializadas e em anais de congressos e de materiais para EAD. Tem experiência na área de Letras, atuando nos seguintes temas: Linguística Funcional Centrada no Uso, Referenciação e Ensino de Língua Portuguesa.

\section{Ivo da Costa do Rosário}

possui graduação em Letras (UERJ) e Pedagogia (UNIRIO). É especialista em Docência do Ensino Fundamental e Médio (FEITA), em Língua Portuguesa (FFP-UERJ) e em Planejamento, Implementação e Gestão da Educação a Distância (LANTE-UFF). É mestre em Língua Portuguesa pela UFRJ e em Letras pela UFF. É doutor em Letras pela UFF e em Letras Vernáculas pela UFRJ. Atualmente é professor adjunto de língua portuguesa e professor permanente do Programa de Pós-Graduação em Estudos de Linguagem da UFF. É líder do grupo de pesquisa CCO (Conectivos e Conexão de Orações) e membro do grupo de Estudos D \& G (Discurso e Gramática), na UFF. Tem interesse nos processos de conexão de orações em perspectiva funcional-construcionista e em questões relacionadas ao ensino de língua portuguesa. 


\section{Patrícia Ferreira Neves Ribeiro}

é Doutora (2007) e Mestre (2000) em Letras Vernáculas (Língua Portuguesa) pela Universidade Federal do Rio de Janeiro - UFRJ. Professora Associada de Língua Portuguesa do Departamento de Letras Clássicas e Vernáculas e do Programa de Pós-Graduação em Estudos de Linguagem da Universidade Federal Fluminense - UFF, vinculada à linha de pesquisa “Teorias do texto, do discurso e da tradução". É membro do projeto integrado de pesquisa CIAD-Rio (Círculo Interdisciplinar de Análise do Discurso) e vice-líder do grupo de pesquisa "Leitura, Fruição e Ensino" (LeiFEn). Desenvolve pesquisas em Linguística do Texto, em Linguística Aplicada ao Ensino de Língua Materna e em Análise do Discurso de orientação Semiolinguística.

\section{Beatriz dos Santos Feres}

é professora associada de Língua Portuguesa do Instituto de Letras da UFF. Atua no Programa de Pós-Graduação em Estudos da Linguagem, desenvolvendo pesquisa acerca da leitura e orientando dissertações e teses. É líder do Grupo de Pesquisa Leitura, fruição e ensino (LeiFEn) e membro do Círculo Interdisciplinar de Análise do Discurso (Ciad-Rio). Participa do GT Linguística de Texto e Análise da Conversação da Anpoll.

\section{Fabio André Coelho}

é professor adjunto de Língua Portuguesa do Instituto de Letras da UFF. Doutor em Língua Portuguesa pela Universidade do Estado do Rio de Janeiro. Mestre em Literatura Portuguesa pela Universidade do Estado do Rio de Janeiro. Tem experiência na área de Letras e outras áreas, atuando principalmente nos seguintes temas: Língua Portuguesa, estilística, leitura, produção textual, metodologia de ensino de língua e literaturas, prática de ensino de língua e literaturas e linguística. Professor pesquisador do Grupo de Pesquisa Descrição e Ensino de Língua: Pressupostos e Práticas (CNPq). 